\title{
Kelly Yoshizaki
}

\section{Efeitos da participação de esteroides-like provenientes da poluição atmosférica no epitélio das vias aéreas em camundongos machos e fêmeas}

Tese apresentada à Faculdade de Medicina da Universidade de São Paulo para obtenção do título de Doutor em Ciências

Programa de Fisiopatologia Experimental Orientadora: Dra. Mariangela Macchione 


\section{Kelly Yoshizaki}

\section{Efeitos da participação de esteroides-like provenientes da poluição atmosférica no epitélio das vias aéreas em camundongos machos e fêmeas}

Tese apresentada à Faculdade de Medicina da Universidade de São Paulo para obtenção do título de Doutor em Ciências

Programa de Fisiopatologia Experimental Orientadora: Dra. Mariangela Macchione

(Versão corrigida. Resolução CoPGr 6018, de 13 de outubro de 2011.

A versão original está disponível na Biblioteca FMUSP) 
Dados Internacionais de Catalogação na Publicação (CIP)

Preparada pela Biblioteca da

Faculdade de Medicina da Universidade de São Paulo

Creprodução autorizada pelo autor

\section{Yoshizaki, Kelly}

Efeitos da participação de esteroides-like proveniente da poluição atmosférica no epitélio das vias aéreas em camundongos machos e fêmeas / Kelly Yoshizaki. -- São Paulo, 2014.

Tese (doutorado)-Faculdade de Medicina da Universidade de São Paulo.

Programa de Fisiopatologia Experimental.

Orientadora: Mariangela Macchione.

Descritores: 1.Poluição do ar 2.Epitélio nasal 3.Identidade de gênero 4.Receptor beta de estrogênio 5.Receptor aril hidrocarboneto 6.Sistema enzimático do citocromo P-450 7.Hidrocarbonetos policíclicos aromáticos 8.Camundongos

USP/FM/DBD-046/14 
Dedico este trabalho com todo carinho a minha família, em especial aos meus pais, meu marido e meus irmãos, que me ajudaram e inspiraram nesta longa caminhada. Obrigada pelo incentivo e carinho. 


\section{AGRADECIMENTOS}

À minha orientadora, Dra Mariangela Macchione, por todo o ensino, apoio e amizade durante os anos de pós-graduação. Agradeço pela acolhida e pela confiança que me foi dada para a condução dos trabalhos.

Ao Prof. Dr. Paulo Hilário Saldiva pelo ensino, suporte e discussão do trabalho.

À Profa. Dra. Thaís Mauad, pelo ensino, atenção e ajuda em diversas ocasiões na análise das lâminas, do trabalho e na elaboração do paper.

Ao Prof. Dr. Luiz Fernando Ferraz Silva, pela ajuda na análise das lâminas e análise de imagem.

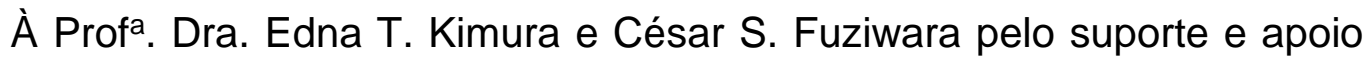
no real-time PCR.

À Prof ${ }^{a}$ Dra. Pérola C Vasconcellos pelo suporte e apoio na coleta e determinação dos HPAs.

À Profa Dra. Mitzi Brentani, pelas importantes sugestões na análise dos resultados.

À Dra. Ana Júlia FC Lichtenfels por fornecer alguns primers para o estudo.

À Profa Dra Elia e Tânia do Programa de Fisiopatologia Experimental.

A Esmeralda, Sandra e a todos do laboratório de Imuno-histoquímica do Departamento de Patologia, pelo apoio na titulação e confecção das lâminas. 
À Cássia, Kelly e todas queridas técnicas do laboratório de Histologia do Departamento de Patologia, pelo apoio na confecção das lâminas.

Ao Aristides T Correia pela colaboração na análise estatística.

Aos amigos que apoiaram este trabalho: Mara, Thaís, Robson, Dra. Regiane Carvalho de Oliveira, Prof ${ }^{a}$ Dra. Naomi Kondo e todos os colegas do Grupo de Defesa Pulmonar, pela amizade e acolhida durante o período de trabalho.

Aos funcionários do LIM 05, LIM20, Museu de Imagens, ICB-USP, IQUSP, FMUSP pela ajuda durante o período de realização deste estudo; aos colegas que trabalham no Laboratório de Poluição Atmosférica Experimental por compartilhar experiências.

À Fundação de Amparo à Pesquisa do Estado de São Paulo (FAPESP) pela concessão da bolsa de doutorado e pelo financiamento deste projeto de pesquisa. 


\section{SUMÁRIO}

Lista de siglas e abreviaturas

Lista de símbolos e unidades

Lista de tabelas

Lista de figuras

Resumo

Summary

1 INTRODUÇÃO 1

1.1 Epitélio Nasal.......................................................................... 7

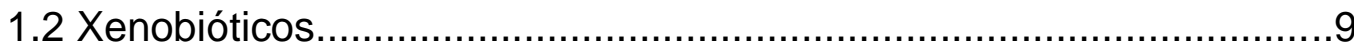

1.3 Receptores de estrógeno ....................................................12

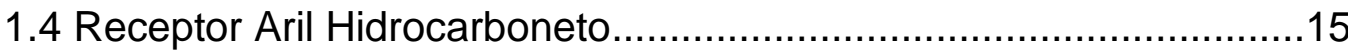

1.5 Ciclo estral de camundongos...................................................16

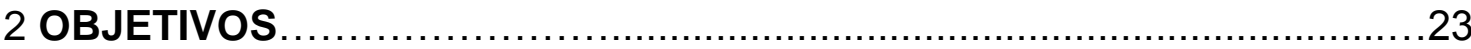

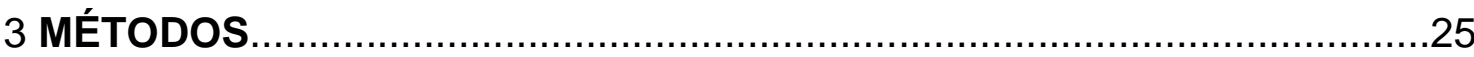

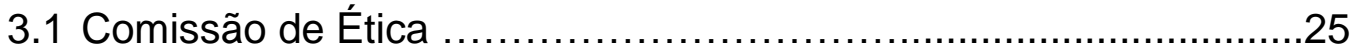

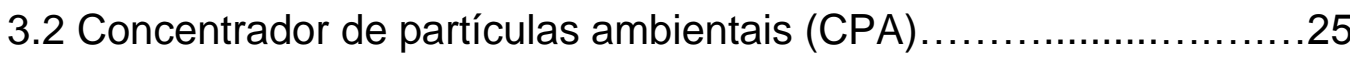

3.3 Amostragem para análise dos HPAs............................27

3.3.1 Preparação dos filtros.........................................28

3.3.2 Coleta do Material Particulado...............................28

3.3.3 Extração e análise das amostras..............................29

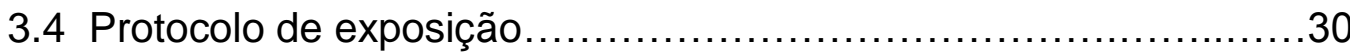

3.5 Grupos experimentais............................................

3.6 Avaliação do ciclo estral .................................................31 
3.7 Coleta e análise do tecido nasal........................................33

3.8 Extração de RNA total e Transcrição Reversa (RT)......................34

3.9 PCR quantitativo em tempo real........................................35

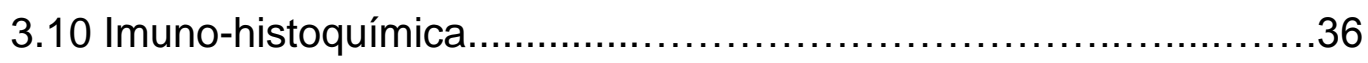

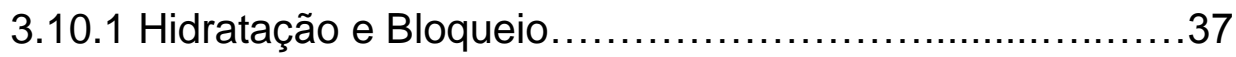

3.10.2 Recuperação antigênica......................................37

3.10.3 Incubação com o anticorpo primário...............................37

3.11 Quantificação da expressão ERbeta e Ahr no epitélio nasal .......38

3.12 Quantificação de muco neutro e ácido no epitélio nasal ..............38

3.13 Quantificação da espessura do epitélio nasal .............................39

3.14 Análise Estatística...................................................40

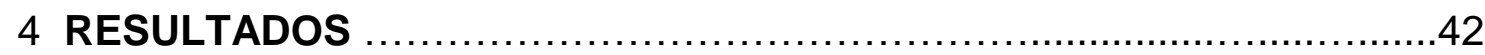

4.1 Análise dos poluentes atmosféricos.................................42

4.2 Determinação dos HPAs................................................42

4.3 Análise do RNAm....................................................... 43

4.4 Análise imuno-histoquímica.................................................56

4.5 Análise do muco ácido e muco neutro .................................60

4.6 Análise da espessura do epitélio nasal...............................66 66

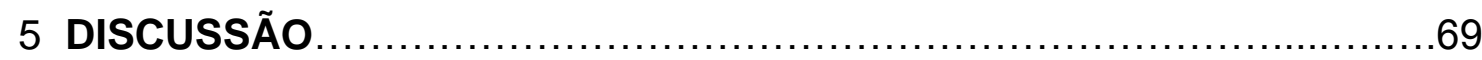

6 CONCLUSÃO

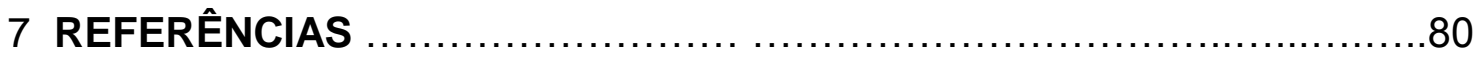

ANEXO 


\section{LISTA DE SIGLAS E ABREVIATURAS}

\begin{tabular}{|c|c|}
\hline Ace & Acenafteno \\
\hline AhR & Receptor aril hidrocarboneto \\
\hline Ant & Antraceno \\
\hline ARNT & Translocador nuclear receptor de aril hidrocarboneto \\
\hline $\mathrm{BaA}$ & Benzo(a)antraceno \\
\hline $\mathrm{BbF}+\mathrm{BkF}$ & Benzo(b)fluoranteno e benzo(k)fluoranteno \\
\hline $\mathrm{BaP}$ & Benzo(a)pireno \\
\hline Bper & Benzo(g,h,i)perileno \\
\hline CETESB & Companhia de Tecnologia de Saneamento Ambiental \\
\hline CPA & Concentrador de partículas ambientais \\
\hline cDNA & DNA complementar \\
\hline CEP & Comissão de Ética em Pesquisa \\
\hline $\mathrm{CO}$ & Monóxido de carbono \\
\hline $\mathrm{C}_{\mathrm{t}}$ & Ciclo do Threshold \\
\hline CYP1A1 & Citocromo P450,família 1, subfamília A, polipeptídeo 1 \\
\hline CYP1A2 & Citocromo P450,família 1, subfamília A, polipeptídeo 2 \\
\hline CYP1B1 & Citocromo P450,família 1, subfamília B, polipeptídeo 1 \\
\hline DAB & Cromógeno 3,3 Diaminobenzidine \\
\hline DBA & Dibenzo antraceno \\
\hline DEPC & Dietilpirocarbonato \\
\hline DMSO & Dimetil sulfoxide \\
\hline DNA & Ácido desoxirribonucleico \\
\hline
\end{tabular}




\begin{tabular}{|c|c|}
\hline DP & Desvio padrão \\
\hline DPOC & Doença Pulmonar Obstrutiva Crônica \\
\hline E1 & Estrona \\
\hline E2 & $17 \beta$-estradiol \\
\hline EDTA & Solução de etileno-diamino-tetracetato de tetrasódio \\
\hline ERB & Receptor de estrógeno beta \\
\hline $\operatorname{Er} \beta-1$ & Receptor de estrógeno beta, isoforma 1 \\
\hline $\operatorname{Er} \beta-2$ & Receptor de estrógeno beta, isoforma 2 \\
\hline ERa & Receptor de estrógeno alfa \\
\hline Et al. & E outros \\
\hline EUA & Estados Unidos da Améria \\
\hline FC & Fibrose cística \\
\hline $\mathrm{Fe}$ & Fenantreno \\
\hline Flu & Fluoreno \\
\hline FMUSP & Faculdade de Medicina da Universidade de São Paulo \\
\hline $\mathrm{FSH}$ & Hormônio folículo-estimulante \\
\hline LBA & Lavado broncoalveolar \\
\hline LH & Hormônio luteinizante \\
\hline HE & Hematoxilina-Eosina \\
\hline HPAs & Hidrocarbonetos policíclicos aromáticos \\
\hline $\ln P$ & Indeno $(1,2,3-c d)$ pireno \\
\hline $\lg E$ & Imunoglobulina E \\
\hline MMP & Matriz metaloproteinase \\
\hline $\mathrm{MP}_{2,5}$ & Material particulado com diâmetro inferior a 2,5 $\mu \mathrm{m}$ \\
\hline $\mathrm{NO}_{3}$ & Nitrato \\
\hline
\end{tabular}


NOx Óxidos de nitrogênio

OMS Organização Mundial de Saúde

$\mathrm{OH} \quad$ Hidroxila

OPCs Pesticidas organoclorados

PAS/AB Ácido Periódico de Schiff e Azul Alciano

PBS Solução salina tamponada com fosfato

PCBs Bifenilos policlorados

PCR Reação em cadeia da polimerase. "Polymerase chain reaction"

RNAm Ácido ribonucleico mensageiro

RT Transcrição reversa

TCDD 2, 3, 7, 8 -tetracloro dioxina dibenzeno

TGF- $\alpha \quad$ Fator de transformação do crescimento alfa

TNF- $\alpha \quad$ Fator de necrose tumoral alfa

VOC Compostos orgânicos voláteis 


\section{LISTA DE SÍMBOLOS E UNIDADES}

$\begin{array}{ll}{ }^{\circ} \mathrm{C} & \text { Percentil } \\ \mathrm{g} & \text { Graus Celsius } \\ \mathrm{m}^{3} & \text { Gramas } \\ \mathrm{mg} & \text { Metro cúbico } \\ \mathrm{mL} & \text { Miligramas } \\ \mathrm{ng} / \mathrm{m}^{3} & \text { Nanograma por metro cúbico } \\ \mathrm{pg} / \mathrm{ml} & \text { Picograma por mililitros } \\ \mathrm{ppm} & \text { Partes por milhão } \\ \mu \mathrm{g} & \text { Micrograma } \\ \mu \mathrm{g} / \mu \mathrm{L} & \text { Micrograma/microlitro } \\ \mu / \mathrm{m}^{3} & \text { Micrômetro por metro cúbico } \\ \mu \mathrm{m} & \text { Micrômetros }\end{array}$




\section{LISTA DE TABELAS}

Tabela 1. Sequências de primers estudados neste trabalho.

Tabela 2. Caracterização e concentrações médias dos HPAs $\left(\mathrm{ng} / \mathrm{m}^{3}\right)$ para as amostras coletas. 


\section{LISTA DE FIGURAS}

Figura 1. Estrutura molecular e potencial relativo do $17 \beta$-estradiol e hiroxi-HPAs exibindo in vitro estrogenicidade.

Figura 2. Respostas de células secretoras das vias aéreas.

Figura 3. Representação esquemática do mecanismo de ação celular dos receptores de estrógeno

Figura 4. Citologia de lavado vaginal reflete eventos endócrinos............. 20

Figura 5. Vista superior do CPA localizado no pátio da FMUSP.............. 25

Figura 6. Câmara de exposição com ar ambiente e câmara de exposição com material particulado $2,5 \mu \mathrm{m}$ de diâmetro $\left(\mathrm{MP}_{2,5}\right)$ concentrado.

Figura 7. Vista interna da câmara de exposição mostrando os animais recebendo ar concentrado de partículas.

Figura 8. Sistema de monitoramento de $\mathrm{MP}_{2,5}$, temperatura e umidade relativa

Figura 9. Amostrador de grande volume.............................................. 29

Figura 10. Ciclo estral........................................................................ 33

Figura 11. Ilustração da superfície ventral e lateral do crânio de camundongo, evidenciando as estruturas utilizadas para marcar o "ponto de corte" da cavidade nasal.

Figura 12. Concentrações médias dos hidrocarbonetos $\left(\mathrm{ng} / \mathrm{m}^{3}\right)$ para as amostras coletas próximo à exposição dos animais

Figura 13. Representação gráfica da expressão de Cyp1a1 RNAm no epitélio nasal de camundongos machos e fêmeas após exposição subcrônica ao ar ambiente e $\mathrm{MP}_{2,5}$ concentrado a $600 \mu \mathrm{g} / \mathrm{m}^{3}$ no CPA

Fiaura 14. Representação gráfica da expressão de Cyp1a1 RNAm no epitélio nasal de camundongos fêmeas em 3 fases do ciclo estral (proestro, estro e diestro), após exposição subcrônica ao ar ambiente e $\mathrm{MP}_{2,5}$ concentrado a $\sim 600 \mu \mathrm{g} / \mathrm{m}^{3}$ no CPAs

Fiqura 15. Representação gráfica da expressão de Cyp1a2 RNAm no epitélio nasal de camundongos machos e fêmeas após exposição subcrônica ao ar ambiente e $\mathrm{MP}_{2,5}$ concentrado a $600 \mu \mathrm{g} / \mathrm{m}^{3}$ no CPA

Figura 16. Representação gráfica da expressão de Cyp1a2 RNAm no epitélio nasal de camundongos fêmeas em 3 fases do ciclo estral (proestro, estro e diestro) após exposição subcrônica ao ar ambiente e MP2,5 concentrado a $~ 600 \mu \mathrm{g} / \mathrm{m}^{3}$ no CPA 
Figura 17. Representação gráfica da expressão de Cyp1b1 RNAm no epitélio nasal de camundongos machos e fêmeas após exposição subcrônica ao ar ambiente e $\mathrm{MP}_{2,5}$ concentrado a $600 \mu \mathrm{g} / \mathrm{m}^{3}$ no CPA.

Figura 18. Representação gráfica da expressão de Cyp1b1 RNAm no epitélio nasal de camundongos machos e fêmeas após exposição subcrônica ao ar ambiente e $\mathrm{MP}_{2,5}$ concentrado a $600 \mu \mathrm{g} / \mathrm{m}^{3}$ no CPA

Figura 19. Representação gráfica da expressão de Erß-1 RNAm no epitélio nasal de camundongos machos e fêmeas após exposição subcrônica ao ar ambiente e $\mathrm{MP}_{2,5}$ concentrado a $600 \mu \mathrm{g} / \mathrm{m}^{3}$ no CPA.

Figura 20. Representação gráfica da expressão de Erß-1 RNAm no epitélio nasal de camundongos fêmeas em 3 fases do ciclo estral (proestro, estro e diestro) após exposição subcrônica ao ar ambiente e $\mathrm{MP}_{2,5}$ concentrado a $\sim 600 \mu \mathrm{g} / \mathrm{m}^{3}$ no CPA

Figura 21. Representação gráfica da expressão de Erß-2 RNAm no epitélio nasal de camundongos machos e fêmeas após exposição subcrônica ao ar ambiente e $\mathrm{MP}_{2,5}$ concentrado a $600 \mu \mathrm{g} / \mathrm{m}^{3}$ no CPAs.

Figura 22. Representação gráfica da expressão de Erß-2 RNAm no epitélio nasal de camundongos fêmeas em 3 fases do ciclo estral (proestro, estro e diestro) após exposição subcrônica ao ar ambiente e MP2,5 concentrado a $\sim 600 \mu \mathrm{g} / \mathrm{m}^{3}$ no CPAs.

Figura 23. Representação gráfica da expressão de AhR RNAm no epitélio nasal de camundongos machos e fêmeas após exposição subcrônica ao ar ambiente e $\mathrm{MP}_{2,5}$ concentrado a $~ 600 \mu \mathrm{g} / \mathrm{m}^{3}$ no CPA.

Figura 24. Representação gráfica da expressão de $A h R$ RNAm no epitélio nasal de camundongos fêmeas em 3 fases do ciclo estral (proestro, estro e diestro) após exposição subcrônica ao ar ambiente e MP2,5 concentrado a $\sim 600 \mu \mathrm{g} / \mathrm{m}^{3}$ no CPA.

Figura 25. Representação gráfica da expressão de $\operatorname{Er} \beta$ (proteína) no epitélio nasal de camundongos machos e fêmeas após exposição subcrônica ao ar ambiente e $\mathrm{MP}_{2,5}$ concentrado a $600 \mu \mathrm{g} / \mathrm{m}^{3}$ no CPA. 
Figura 26. Representação gráfica da expressão protéica de $\operatorname{Er} \beta$ no epitélio nasal de camundongos fêmeas em 3 fases do ciclo estral (proestro, estro e diestro) após exposição subcrônica ao ar ambiente e $\mathrm{MP}_{2,5}$ concentrado a $\sim 600 \mu \mathrm{g} / \mathrm{m}^{3}$ no CPA

Figura 27. Representação gráfica da expressão protéica de AhR no epitélio nasal de camundongos machos e fêmeas após exposição subcrônica ao ar ambiente e $\mathrm{MP}_{2,5}$ concentrado a $600 \mu \mathrm{g} / \mathrm{m}^{3}$ no CPA.

Figura 28. Representação gráfica da expressão proteica de AhR no epitélio nasal de camundongos fêmeas em 3 fases do ciclo estral (proestro, estro e diestro) após exposição subcrônica ao ar ambiente e $\mathrm{MP}_{2,5}$ concentrado a $\sim 600 \mu \mathrm{g} / \mathrm{m}^{3}$ no CPA.

Figura 29. Fotomicrografias do epitélio nasal de camundongos

Figura 30. Representação gráfica da expressão de muco neutro no epitélio nasal (porcentagem) de camundongos machos e fêmeas após exposição subcrônica ao ar ambiente e $\mathrm{MP}_{2,5}$ concentrado a $\sim 600 \mu \mathrm{g} / \mathrm{m}^{3}$ no CPA

Figura 31. Representação gráfica da expressão de muco neutro no epitélio nasal (porcentagem) de camundongos fêmeas em 3 fases do ciclo estral (proestro, estro e diestro) após exposição subcrônica ao ar ambiente e $\mathrm{MP}_{2,5}$ concentrado a $\sim 600 \mu \mathrm{g} / \mathrm{m}^{3}$ no CPA.

Figura 32. Representação gráfica da expressão de muco ácido no epitélio nasal (porcentagem) de camundongos machos e fêmeas após exposição subcrônica ao ar ambiente e $\mathrm{MP}_{2,5}$ concentrado a $600 \mu \mathrm{g} / \mathrm{m}^{3}$ no CPA

Figura 33. Representação gráfica da expressão de muco ácido no epitélio nasal (porcentagem) de camundongos fêmeas em 3 fases do ciclo estral (proestro, estro e diestro) após exposição subcrônica ao ar ambiente e MP ${ }_{2,5}$ concentrado a $\sim 600 \mu \mathrm{g} / \mathrm{m}^{3}$ no CPA

Figura 34. Representação gráfica da espessura do epitélio nasal $(\mu \mathrm{m})$ de camundongos machos e fêmeas após exposição subcrônica ao ar ambiente e $\mathrm{MP}_{2,5}$ concentrado a $600 \mu \mathrm{g} / \mathrm{m}^{3}$ no CPA

Figura 35. Representação gráfica da espessura do epitélio nasal $(\mu \mathrm{m})$ de camundongos fêmeas em 3 fases do ciclo estral (proestro, estro e diestro) após exposição subcrônica ao ar ambiente e 


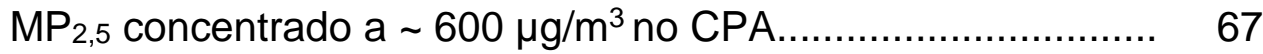




\section{RESUMO}

Yoshizaki K. Efeitos da participação de esteroides-like provenientes da poluição atmosférica no epitélio das vias aéreas em camundongos machos e fêmeas. [Tese]. São Paulo: Faculdade de Medicina, Universidade de São Paulo; 2014.

O epitélio nasal é a primeira porção do sistema respiratório a entrar em contato com o ambiente externo. Partículas da poluição do ar, principalmente os compostos orgânicos absorvidos, podem atuar como liberadores endócrinos. $O$ receptor aril hidrocarboneto $(\mathrm{AhR})$ é um importante competidor dos receptores de estrógeno- $\beta$ (ER $\beta)$ que regulam a transcrição do gene para enzimas de metabolização xenobióticas (enzimas do citocromo P450). O objetivo deste estudo é identificar e quantificar ERß, AhR, CYP1A1, CYP1A2, CYP1B1 e o perfil de muco no epitélio nasal de camundongos machos e fêmeas em diferentes fases do ciclo estral. Camundongos BALB/C machos $(\mathrm{n}=32)$ e fêmeas $(n=84)$ foram expostos ao ar ambiente e ao $M_{2,5}$ concentrado a 600 $\mu \mathrm{g} \cdot \mathrm{m}^{-3}$ em um concentrador de partículas ambientais (CPAs). As fêmeas foram divididas de acordo com as fases do ciclo estral: proestro, estro e diestro. $\mathrm{O}$ epitélio nasal foi avaliado por RT-PCR e imuno-histoquímica para análise de expressão de ERß (proteína), Erß-1 e Erß-2 (gene), AhR (proteína e gene) e Cyp1a1, Cyp1a2 and Cyp1b1 (gene). A quantificação de muco neutro - Periodic Acid Schiff's (PAS+) e ácido - Alcian Blue $(A B+)$ foi avaliada por morfometria. As exposições foram realizadas durante 5 dias/semana, por $45 \pm 55$ dias. A expressão de $\operatorname{Er\beta }-2$ RNAm apresentou diferenças em resposta à exposição ao CPAs $(p=0,016)$, bem como uma diminuição em fêmeas, quando comparadas 
aos camundongos machos $(p=0,036)$. A expressão de Cyp1b1 RNAm foi significantemente menor no grupo exposto ao CPAs, em relação ao grupo exposto ao ar ambiente nas fêmeas em diestro $(p=0,036)$. A expressão de Er $\beta$ foi aumentada no epitélio nasal de fêmeas em estro expostas ao CPAs $(p=0,005)$ e a expressão de AhR foi menor em fêmeas em proestro expostas ao CPAs $(p=0,048)$. A exposição ao CPAs levou ao aumento do conteúdo de muco ácido em camundongos machos $(p=0,048)$, o qual diminuiu em fêmeas $(p=0,040)$, quando comparados ao grupo ar ambiente. Este estudo mostrou que houve diferentes respostas à exposição à poluição do ar no epitélio nasal entre machos e fêmeas, e que essas diferenças podem estar relacionadas com a predisposição de fêmeas apresentarem maior suscetibilidade a doenças respiratórias das vias aéreas.

Descritores: Poluição do ar, epitélio nasal, identidade de gênero, receptor beta de estrogênio, receptor aril hidrocarboneto, sistema enzimático do citocromo P450, hidrocarbonetos policíclicos aromáticos, camundongos. 


\section{SUMMARY}

Yoshizaki K. Effects of the participation of steroid-like compounds from air pollution in the airway epithelium of male and female mice. [Tese]. São Paulo: "Faculdade de Medicina, Universidade de São Paulo"; 2014.

The nasal epithelium is the first portion of the respiratory system to reach contact with the external environment. Air pollution particles, mainly the organic compounds absorbed into them, may act as endocrine releasers. The aryl hydrocarbon (AhR) receptor is an important competitor of estrogenic receptors$\beta(E R \beta)$ that regulate transcription of gene coding for xenobiotic-metabolizing enzymes (cytochrome P450 enzymes). The aim of this study is to identify and quantify in the nasal epithelium of male and female mice in different estrous cycle phases related with ER $\beta, A h R, C Y P 1 A 1,1 A 2,1 B 1$ and the mucus profile. Male $(n=32)$ and female $(n=84)$ BALB/c mice were exposed to ambient air and $\mathrm{PM}_{2.5}$ concentrated at $600 \mu \mathrm{g} \cdot \mathrm{m}^{3}{ }^{3}$ in an ambient particle concentrator with a particulate matter diameter of $2.5 \mu \mathrm{m}\left(\mathrm{PM}_{2.5}\right)$. Females were subdivided in three estrous cycles: proestrus, estrus and diestrus. Nasal epithelium was evaluated through RT-PCR and immunohistochemistry for the expression of ER $\beta$ (protein), Er $\beta-1$ and Er $\beta-2$ (gene expression), AhR (protein and gene expression) and Cyp1a1, Cyp1a2 and Cyp1b1 (gene expression). Morphometry was applied for evaluation of mucus profile: acid - Alcian Blue $(A B+)$ and neutral - Periodic Acid Schiff's (PAS+). Exposure happened for 5 days/week, for $45 \pm$ 55 days. There were differences in Erß-2 mRNA in response to exposition to CPAs $(p=0.016)$, and a significant decrease in female compared male mice $(\mathrm{p}=0.036)$. Cyp1b1 mRNA was significantly smaller in the CPAs-exposed group 
compared with the ambient air group in diestrus female mice $(p=0.036)$. The ER $\beta$ expression increased in the nasal epithelium of CPAs-exposed females in the estrus cycle $(p=0.005)$, and the AhR expression decreased in the proestrus cycle of CPAs-exposed females $(p=0.048)$. The exposure to the CPAs led to an increase in the acidic content of mucus in male mice $(p=0.048)$, and decreased in female mice $(p=0.040)$, compared to the ambient air group. This study showed there were different responses in the nasal epithelia of male and female mice exposed to air pollution, which could be related to the predisposition of the females to present more susceptibility to airway respiratory diseases.

Descriptors: Air pollution; nasal epithelium; gender identity; estrogen receptor beta; aryl hydrocarbon receptor (AhR); cytochrome P-450 enzyme system; hydrocarbon polycyclic aromatic; mice. 
INTRODUÇÃO 


\section{Introdução}

Tem-se observado um recente aumento de doenças inflamatórias pulmonares tais como a asma, doença pulmonar obstrutiva crônica (DPOC) e fibrose cística (FC). Embora essas condições apresentem distintas fisiopatologias, as mulheres apresentam maior prevalência à morbidade e mortalidade com relação a essas doenças (Han et al., 2007; Wise, 1997). Por exemplo, nos Estados Unidos (EUA), mais de $60 \%$ de todos os pacientes adultos com asma são mulheres, e, em relação ao sexo masculino, asmáticas são $50 \%$ mais propensas a realizar consultas médicas, têm $35 \%$ a mais de probabilidade de sofrer internações e são $40 \%$ mais propensas a morrer de asma (Centers for Diseases Control and Prevention, 2010).

Embora os homens tenham maior prevalência de DPOC do que as mulheres, o aumento de taxas de tabagismo em mulheres nas últimas décadas tem sido associado com o aumento de taxas de DPOC em mulheres (Wise, 1997). Em 2000, pela primeira vez, o número de mulheres que morrem de DPOC nos EUA superara o número de homens (Han et al., 2007). Mesmo nos casos em que o cigarro esteja envolvido, mulheres desenvolvem a DPOC após fumar um número menor de cigarros durante a vida (ou seja, menos maço/ano de tabaco) (Gillum et al., 2005) e são de duas a três vezes mais propensas a hospitalizações do que os pacientes do sexo masculino (Prescott et al., 1997). Entre os familiares de primeiro grau de pacientes com DPOC grave, as mulheres que fumam demonstram menor função pulmonar em relação aos parentes fumantes do sexo masculino (Silverman et al., 2000). Em pacientes com DPOC grave, com dependência de oxigênio, as mulheres têm um 
aumento de $50 \%$ no risco de mortalidade em comparação com os homens (Machado et al., 2006). Por fim, embora fibrose cística seja uma doença genética rara que afeta tanto homens como mulheres, por razões pouco conhecidas em grande parte, os pacientes do sexo feminino têm expectativa de vida menor em comparação aos doentes do sexo masculino (Townsend et al., 2012). Coletivamente, esses dados epidemiológicos sugerem que o gênero feminino é um fator de risco significativo para a morbidade e mortalidade em doenças inflamatórias pulmonares e levantam a possibilidade de que os hormônios relacionados com o sexo possam ser importantes na mediação da progressão da doença na asma, DPOC e FC, embora os mecanismos pelos quais isso ocorre possam ser diferentes entre essas doenças .

Uma exposição por períodos longos a altos níveis de partículas e gases da poluição atmosférica tem um grande efeito na saúde de humanos e animais, principalmente no sistema cardiorrespiratório (Pope et al., 2004; Delfino et al., 2005). Esse impacto na saúde tem também sido associado com o sistema endócrino, interferindo no desenvolvimento fetal (Srám et al., 2005) e com a diminuição na fertilidade masculina (De Rosa et al., 2003). O exato mecanismo ligado a esse fenômeno ainda permanece com várias lacunas. Uma hipótese está relacionada a substâncias químicas liberadas pelas partículas da poluição atmosférica (Sioutas et al., 2005), agindo como liberadoras endócrinas (Clemons et al., 1998; Watanabe, Kurita, 2001; Wang et al., 2004; Sidhu et al., 2005; Klein et al., 2006; Wenger et al., 2009). As partículas interfeririam com o funcionamento normal do sistema endócrino pela mimetização ou antagonização dos hormônios ou/e modulação das respostas hormonais 
(Damstra et al., 2002), podendo levar a efeitos adversos à saúde como a liberação de esteróides gonadais, como estrógenos.

O efeito da exposição crônica à poluição do ar na reprodução foi previamente estudado na cidade de São Paulo (Mohallem et al., 2005; Lichtenfels et al., 2007). Esses estudos observaram que a exposição a níveis ambientais de poluição afetou a reprodução, como a diminuição do número de fetos e diminuição da razão homem/mulher, nos estudos experimentais em camundongos expostos ao ar da cidade de São Paulo durante o período de exposição de 4 meses no ano de 2001. Os estudos ainda mostraram uma diminuição na qualidade do sêmen em homens que trabalham em situações expostas ao tráfico urbano (De Rosa et al., 2003). A poluição do ar também interfere no ciclo estral, como foi observado por Veras et al. (2009), em camundongos expostos dentro de uma câmara de exposição, que aumentaram o número de dias do ciclo em estro.

Há evidência de que os hidrocarbonos policíclicos aromáticos (HPAs) apresentam similaridades estruturais com os hormônios esteroides, como o estrogênio, primeiramente descrita por Clemons et al. (1998) e posteriormente confirmada por outros dois estudos in vitro (Wang et al., 2004; Klein et al., 2006). A semelhança estrutural pode ser observada na . Vários hidroxiHPAs, como os derivados hidroxilados de benzo[a]pireno e criseno, têm mostrado possuir atividade estrogênica (Hayakawa et al., 2007). 


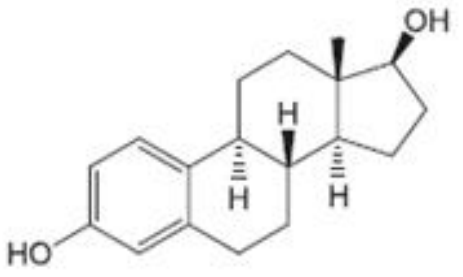

1

1.0

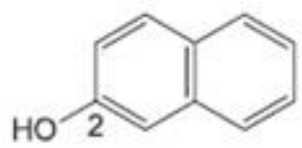

3

$1.5 \times 10^{-7}$<smiles></smiles>

2

$6.5 \times 10^{-6}$<smiles>Oc1ccc2ccccc2c1</smiles>

4

$1.1 \times 10^{-6}$

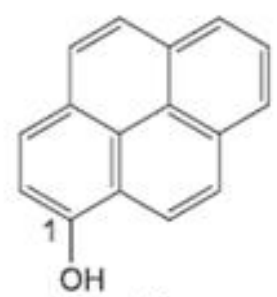

$3.7 \times 10^{-7}$

5

$1.0 \times 10^{-5}$

Figura 1. Estrutura molecular e potencial relativo de $17 \beta$-estradiol (1) e hidroxi-HPAs (2-6) exibindo in vitro estrogenicidade. Os hidroxi-HPAs são: 1-hidroxonaftaleno (2), 2hidroxonaftaleno (3), 2-hidroxifenatrene (4), 2-hidroxocriseno (5) e 1-hidroxipireno (6). (Wenger et al., 2009).

Portanto, a hipótese de que hidroxi-HPAs contribuem de alguma forma para a atividade estrogénica foi previamente observada em partículas do ambiente (Clemons et al., 1998; Wang et al., 2004; Klein et al., 2006). Na atmosfera, hidroxi-HPAs são formados por oxidação secundária de HPA na fase gasosa, envolvendo radicais hidroxi $(\mathrm{OH} \bullet)$ durante os dias e radicais de nitrato (NO3 •) durante a noite (Vione et al., 2004). Durante a noite, hidroxiHPAs podem ainda reagir a nitro-oxi-HPAs. Hidroxi-HPAs são geralmente menos voláteis do que o progenitor HPA e tendem a ser mais associados com o material particulado (Vione et al., 2004). Além de processos atmosféricos, hidroxi-HPAs e seus precursores são emitidos diretamente a partir de processos de combustão e são encontrados, por exemplo, em escape de motores a diesel (Sidhu et al., 2005; Heeb et al., 2008). Além disso, HPAs hidroxilados podem ser formados nos organismos após a ingestão de HPAs parenterais, através de biotransformação catalisada pelo citocromo P450 (CYP) 
(Charles et al., 2000; Fertuck et al., 2001; van Lipzig et al., 2005). In vitro, a estrogenicidade observada com determinados HPAs é suspeita de ser predominantemente formada por seus metabolitos hidroxilados nas células expostas (Charles et al., 2000; Fertuck et al., 2001; van Lipzig et al., 2005).

No Brasil, a população urbana é afetada pela poluição do ar emitida pelos veículos. No entanto, cada cidade tem uma característica específica de emissão. A região metropolitana de São Paulo tem a maior frota de veículos no Brasil, com mais de sete milhões de veículos. Veículos com mais de 10 anos de idade representam $50 \%$ da frota e são responsáveis pela maioria das emissões. O relatório da CETESB (2012) indica que, em São Paulo, mais de 85\% das emissões de monóxido de carbono (CO), compostos orgânicos voláteis (VOC) e óxido de nitrogênio (NOx) são derivadas de fontes móveis (CETESB, 2012).

A poluição do ar por compostos orgânicos é avaliada por análise de indicadores de classes contaminantes, como hidrocarbonetos policíclicos aromáticos (HPAs), bifenilos policlorados (PCBs) ou pesticidas organoclorados (OCPs). A contaminação do ar consiste de complexas misturas químicas que poderiam produzir efeitos potencialmente tóxicos.

A mucosa nasal é a primeira porção do sistema respiratório a entrar em contato com o meio ambiente e, portanto, com a poluição atmosférica. Além disso, o epitélio nasal sofre a interferência do controle hormonal e um número considerável de sintomas nasais tem sido descrito em associação com mudanças hormonais (Toppozada et al., 1981). Há evidências na literatura mostrando uma relação entre hormônios ovarianos e mudanças na fisiologia do ciclo estral (Navarrete-Palacios et al., 2003). Saldiva et al. (1995) 
demonstraram diferenças entre ratos machos e fêmeas relacionadas ao clearance mucociliar, reologia do muco e morfometria quando expostos à poluição urbana. Diferenças foram observadas no clearance ciliar e na reologia do muco em machos que apresentaram maior quantidade de glicoproteínas ácidas estocadas no epitélio nasal do que em que fêmeas em estro.

\subsection{Epitélio Nasal}

Como já mencionado, a primeira porção do sistema respiratório a entrar em contato com o meio externo e, consequentemente, com a poluição atmosférica, é o nariz (Schawab et al., 1998), a primeira barreira mecânica contra vários agentes nocivos inalados (Takizawa, 1998).

Em humanos, a mucosa nasal consiste de uma lâmina, uma membrana basal e um epitélio. Na região anterior da cavidade nasal, próximo à concha inferior, três tipos de epitélio estão presentes: epitélio escamoso, epitélio celular cúbico estratificado e epitélio pseudo-estratificado, com poucas células ciliadas. Entre a concha média e a concha inferior da mucosa nasal, o epitélio é tipicamente respiratório.

Normalmente, o epitélio nasal dos ratos é composto de células basais, células indiferenciadas, células ciliadas e células caliciformes produtoras de muco ou células mucosas. Esse epitélio tem a aparência de um epitélio colunar pseudo-estratificado. Quando submetidas à lesão, as células ciliadas desaparecem e são substituídas por células mucosas, resultando em um epitélio com hiperplasia de células caliciformes (Kuiper et al., 1998) (Figura 2). 


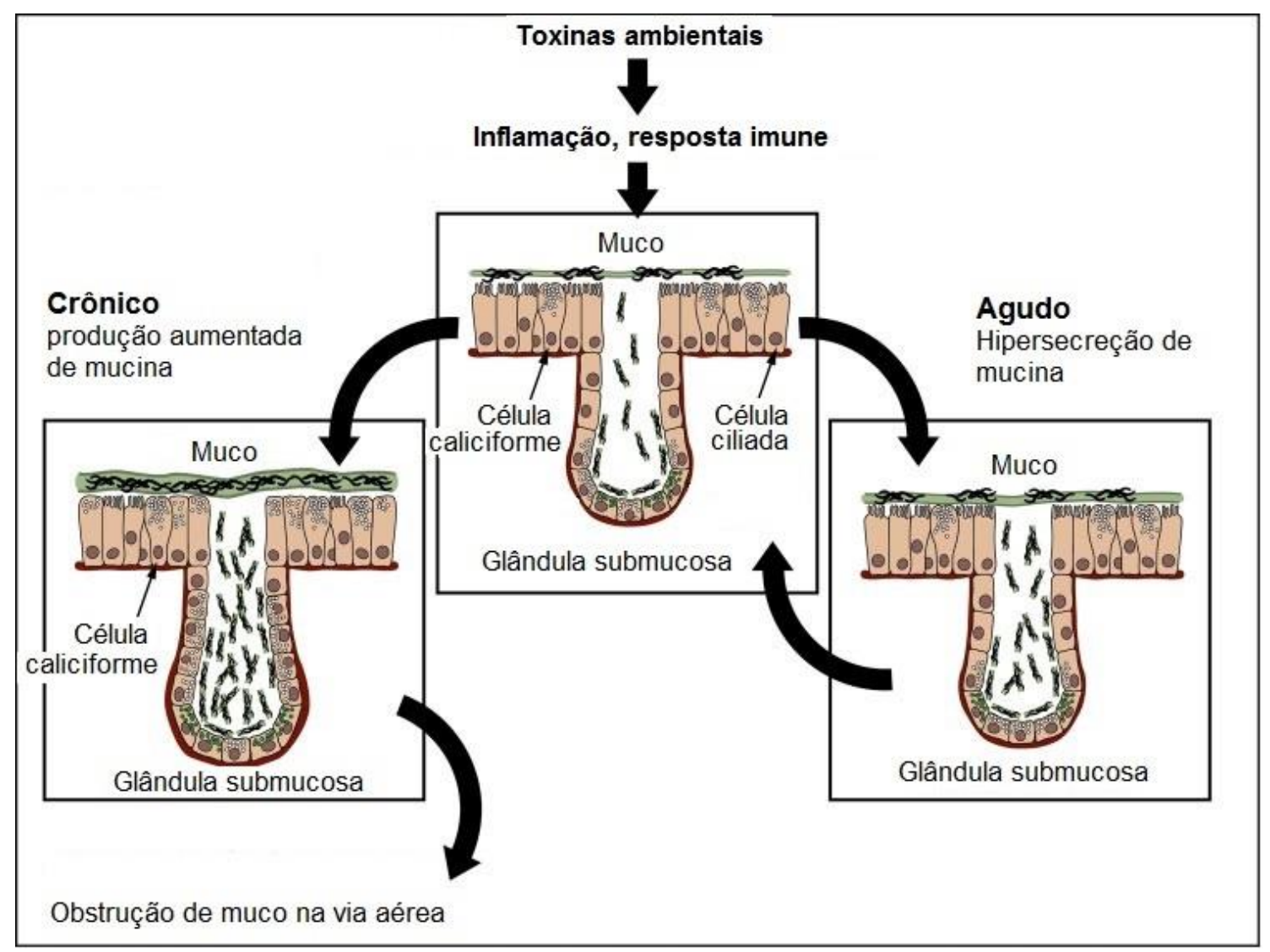

Figura 2. Respostas de células secretoras das vias aéreas (adaptado de Rose; Voynow, 2006).

Há trabalhos na literatura mostrando uma relação entre os hormônios ovarianos e alterações na fisiologia nasal. Desde o século XIX observa-se que o ciclo menstrual e a gravidez têm um efeito sobre a vascularização nasal e a secreção de muco (Holmes et al., 1950, Robinson et al., 2007). Durante a gravidez, o nível de estrógeno e de progesterona aumenta consideravelmente e estima-se que mais de $40 \%$ das mulheres sofram de rinite na gestação (Bende et al., 1999). Estudos ao longo dos últimos 30 anos têm indicado uma ligação entre as alterações hormonais que ocorrem na gravidez e sintomas nasais. (Ellegard, Karlsson, 1999; Bende et al.,1999 ; Philpott et al., 2004). 
Navarrete-Palacios et al. (2003) investigaram se poderia haver uma relação entre as características citológicas do epitélio nasal de mulheres e a fase do ciclo menstrual. Os resultados do estudo indicaram uma correlação entre a fase do ciclo menstrual e a característica citológica do epitélio nasal e o trato reprodutivo feminino. Houve predominância de células cornificadas durante a fase folicular e células epiteliais arredondadas durante a fase lútea, mostrando uma correlação entre as características citológicas do lavado vaginal e das células do epitélio nasal com os estágios do ciclo (NavarretePalacios et al., 2003). Esses estudos são inéditos nesse campo e a demonstração e descrição de uma relação entre ciclo menstrual e as características do epitélio nasal poderiam ser úteis na compreensão de sintomas nasais associados com o ciclo reprodutivo feminino e a associação entre volume celular e estado hormonal geral.

\subsection{Xenobióticos}

Os efeitos dos compostos da poluição do ar responsáveis pela metabolização enzimática do tecido nasal são particularmente interessantes devido ao papel do epitélio nasal como local de contato inicial com produtos tóxicos inalatórios, em concentrações maiores que as encontradas em outros tecidos.

Xenobióticos são substâncias químicas naturais ou artificiais estranhas ao organismo. Os poluentes e produtos industriais são alguns exemplos de agentes que necessitam de uma metabolização endócrina. Em seu estado natural ou biotransformados, os xenobióticos podem afetar a integridade do DNA. O metabolismo dos xenobióticos é catalisado por um conjunto de 
enzimas que também estão envolvidas na metabolização de substratos endógenos, como hormônios esteróides, ácidos graxos e ácidos biliares. Essas enzimas são predominantemente encontradas em tecidos altamente expostos a xenobióticos, como fígado, pulmões, intestinos e rins. A inativação de xenobióticos possibilita a preservação da integridade celular (Wilkinson; Clapper, 1997).

O processo de detoxificação é composto por duas fases, baseadas em suas prioridades funcionais. Nas reações da Fase I (metabolismo oxidativo), as enzimas ativam o xenobiótico, tornando-o mais eletrolítico e mais reativo. As enzimas são mediadas pelo complexo citocromo P450, e um grupo polar é introduzido na molécula, o que aumenta a hidrossolubilidade, tornando-as adequadas para as reações de conjugação (Fase II). Nas reações da Fase II, os compostos modificados pelas reações da Fase I reagem com um substrato endógeno, produzindo compostos conjugados hidrossolúveis e facilitando sua excreção (Rushmore; Kong, 2002).

Em humanos, as principais enzimas pertencentes à família CYP1 são: CYP1A1, CYP1A2 e CYP1B1. CYP1A é a enzima mais ativa que catalisa a bioativação aos agentes mutagênicos de muitos HPAs, como o benzo (a) pireno, bem como de várias aminas heterocíclicas (Iba et al., 2000). Devido a sua afinidade com diversos substratos, essa enzima apresenta importância no processo de detoxificação. A atividade do citocromo P450 é influenciada por vários fatores, tais como genética, nutrição e a exposição prévia a outros produtos químicos (loannides, Parke, 1993; Parke, loannides, 1994; Kroemer, Eichelbaum, 1995). A CYP1A2 metaboliza uma grande variabilidade de fármacos. CYP1A1 e 1A2 são as principais enzimas responsáveis para a 
bioativação de benzo(a) pireno (B[a]P) (Ma et al., 2007). Na presença de hidrolase, CYP1A1/1A2 e 1B1 catalisam a conversão de B[a]P em 7-8-epóxido e, consequentemente, para 7-8-diidrodiol, e ambas as enzimas podem tornarse metabolicamente ativas.

A CYP1B1 metaboliza numerosos HPAs, bem como as aminas $\mathrm{N}$ heterocíclica, arilaminas e outros carcinógenos. A expressão de CYP1B1 é alta em células endoteliais dos vasos, da próstata, do útero, da camada epitelial da cabeça e do pescoço, em vários tipos de tumores e no córtex adrenal. (Nebert et al., 2004).

O efeito da fumaça de cigarro no citocromo P450 no nariz tem sido pouco investigado e, aos poucos, surge conhecimento de outros possíveis efeitos que induzem o P450 no nariz (Wardlaw et al., 1998).

Trabalhos anteriores relatam diferentes respostas à exposição ao naftaleno, composto pertencente aos HPAs, em relação ao gênero. Uma exposição crônica ao vapor naftaleno resulta no aumento de incidência de carcinomas pulmonares brônquico-alveolares, em camundongos fêmeas (NTP, 1992). Diferenças de gênero foram também observadas após a administração de naftaleno. Camundongos fêmeas (aleatórias, fase do ciclo estral indeterminada) apresentam respostas diferentes, com início precoce e extensão da lesão epitelial das vias respiratórias, em relação aos machos, quando submetidos à mesma dose (Van Winkle et al., 2002). Além disso, os subcompartimentos pulmonares de camundongos fêmeas metabolizam o naftaleno mais rapidamente, com uma maior proporção de formação de metabólito diidrodiol do que os dos machos (Stelck et al., 2005). 


\subsection{Receptores de estrógeno}

Os receptores de estrógeno (estrogen receptors - ER) pertencem à superfamília dos receptores nucleares para fatores de transcrição (Giangrande; Macdonnel, 1999). O mecanismo de ação dos receptores de estrógeno pode ser representado esquematicamente como na Figura 3. Enquanto não estão ligados aos estrógenos, os receptores permanecem inativos, não interferindo com a transcrição do ácido desoxirribonucleico (DNA) celular. Quando o estrógeno se liga aos receptores de estrógeno, estes sofrem mudanças em sua conformação de monômeros para dímeros. Os dímeros acoplam-se a regiões específicas do DNA celular, denominadas elementos de resposta aos estrógenos. Essas regiões do DNA localizam-se nas proximidades do segmento que contém a sequência promotora da transcrição de um gene (Kurebayashi et al., 1997). 


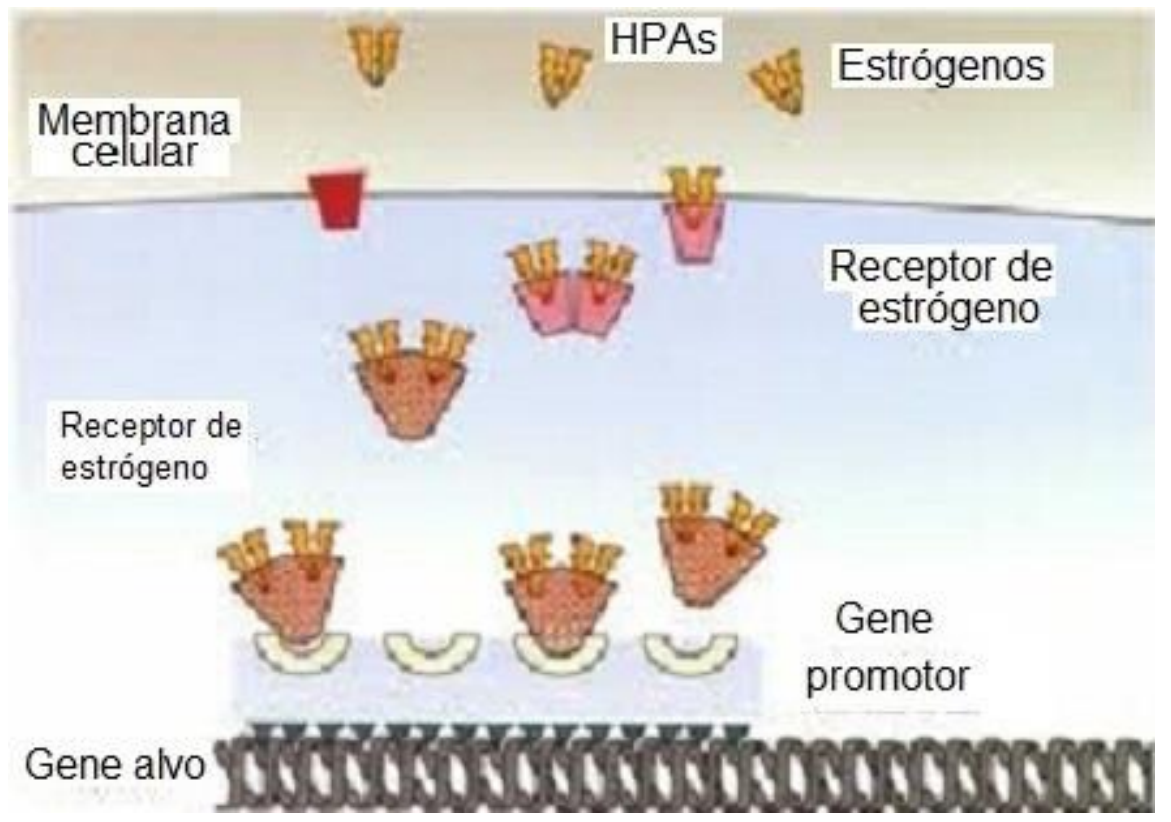

Figura 3. Representação esquemática do mecanismo de ação celular dos receptores de estrógeno.

Os ER encontrados na mucosa nasal são de dois subtipos (ERa, ERß) e pertencem à superfamília de receptores nucleares. Funcionam como um ligante, induzindo um fator de transcrição e mediando os efeitos do estrógeno natural, dos quais o 17ß-estradiol (E2) é o principal estrogênio endógeno. Os estrógenos regulam o crescimento, a diferenciação e o funcionamento de diferentes tecidos-alvo (Villeneuve et al., 1998; Wenger et al., 2009).

Durante a secreção de hormônios, a expressão de receptores de estrógeno e progesterona é influenciada por fatores imunológicos, mostrando que há uma correlação entre o sistema endócrino e o sistema imunitário (Talal et al., 1987; Farina et al., 1996; Piccinni et al., 1995; Stübner et al., 1999). Toppozada et al. (1981) observaram, por meio de microscopia eletrônica e análise histoquímica, alterações na mucosa nasal causadas por hormônios sexuais femininos em mulheres grávidas que sofrem de rinite alérgica. Konno 
et al. (1986) demonstraram em cobaias que a gravidez induziu um significante decréscimo na densidade de receptores a1-adrenérgicos na mucosa nasal e que a aplicação de estrógeno em cobaias não grávidas aumentou a densidade de receptores muscarínicos, enquanto que a progesterona diminuiu essa concentração, o que sugere que mudanças hormonais femininas no epitélio da mucosa nasal facilitam o desenvolvimento de sintomas de hiper-reatividade nasal.

No entanto, as vias pelas quais os hormônios agem sobre a mucosa ainda são contestadas e, embora tenham sido objeto de vários estudos (Krasnow et al., 1996; Hamano et al., 1998), mais esclarecimentos são ainda necessários.

Em 2004, Shirasaki et al. demonstraram a presença de altas quantidades de receptores de glicocorticoide dentro de todas as células da mucosa nasal (células epiteliais, glândulas submucosas e leucócitos inflamatórios) e de receptores de estrógeno- $\alpha$ principalmente em mastócitos e receptores de estrógeno $\beta$ em glândulas submucosas. Mais tarde, Philpott et al. (2008) demonstraram, por meio da técnica de imuno-histoquímica, que receptores de estrógeno $\beta$ estavam presentes nas glândulas submucosas de 24 das 25 biópsias feitas em pacientes com rinite alérgica, e que houve uma relação positivamente significante entre o número de receptores de estrógeno $\beta$ e sintomas nasais. Além disso, a expressão dos receptores de estrógeno pareceu não estar relacionada ao sexo, história de fumo, status hormonal, idade ou atopia. 


\subsection{Receptor Aril Hidrocarboneto}

Os xenobióticos, como os hidrocarbonetos policíclicos aromáticos (HPAs), estão presentes no meio ambiente (Chopra; Schrenk, 2011). HPAs são distribuídos principalmente como resultado das atividades humanas ou fenômenos naturais, e exercem seus efeitos biológicos através do receptor aril hidrocarbono (AhR). A ativação do AhR pode iniciar uma série de mudanças na expressão gênica, que pode levar à carcinogenicidade e à indução de enzimas de biotransformação, tais como citocromo P450 1A (CYP1A) (Mandal, 2005).

O receptor aril hidrocarboneto ( $A h R$ - aryl hydrocarbon receptor) e seu par nuclear, o translocador nuclear receptor de aril hidrocarboneto (ARNT-aryl hydrocarbon receptor nuclear translocator), são expressos no trato reprodutivo de fêmeas em uma grande variedade de espécies. Várias indicações sugerem que o AhR poderia representar um papel importante na fisiologia da reprodução. Como exemplo, modelos animais AhR-knockout demonstraram uma quantidade de deficiências reprodutivas incluindo a morte de fêmeas durante a gravidez e a lactação (Fernandez-Salguero et al., 1997).

Outro estudo sobre AhR apontou-o como regulador transcripcional dos genes que codificam as enzimas metabolizadoras de xenobióticos, como as dos citocromos P450 ou CYP, principalmente em células do fígado (Hillegass et al., 2006). A ligação de AhR-ARNT ativa o complexo para seu sítio de reconhecimento específico no DNA, "elemento responsivo ao xenobiótico" (XRE), dentro da região promotora dos genes, o que resulta no aumento de sua transcrição (Denison et al., 1988). Para entendermos a função de AhR, por

exemplo, a droga 2, 3, 7, 8 -tetracloro-dioxina-dibenzeno (TCDD) induz a 
transcrição de CYP1A1 porque esse gene codifica enzimas do citocromo P450 1A1, o qual oxigena vários xenobióticos como parte de seus passos para detoxificação (Conney, 1982). Embora a ativação transcripcional de membros da família do P450 pelo ligante AhR seja bem conhecida, novas rotas de ação de mediação do AhR têm sido propostas. CYP1A1, 1A2 e 1B1 mostraram ser uma família de enzimas no metabolismo pró-carcinógeno, como hidrocarbonetos policíclicos aromáticos (HPAs), nitro-HPAs, aril e arilalaminas heterocíclicas, que podem ser encontrados na poluição atmosférica (Hayakawa et al., 2007).

Responsáveis por casos de contaminação ambiental, os HPAs pertencem a uma classe de produtos químicos originados no petróleo, na combustão incompleta ou pirólise de materiais contendo carbono e hidrogênio. A prevalência de doenças alérgicas vem aumentando com o passar dos anos. A exposição a xenobióticos ambientais (substâncias químicas naturais ou artificiais estranhas ao organismo) é descrita como um dos fatores de risco ao desenvolvimento de atopia e asma (Arruda et al., 2005). O trato respiratório é um dos tecidos que entram em contato com esses produtos químicos exógenos presentes em escapamento de automóveis e fumaça de cigarro. Na mucosa nasal, o estrógeno apresenta efeito vasodilatador em estudos com ratos.

\subsection{Ciclo estral de camundongos}

Em razão da curta duração de seu ciclo estral, camundongos fêmeas constituem um bom modelo para o estudo das alterações que ocorrem durante o ciclo reprodutivo. O ciclo estral de camundongos fêmeas tem duração média 
de quatro a cinco dias e é caracterizado por quatro fases: proestro, estro, metaestro e diestro, as quais podem ser determinadas pelos tipos celulares observados no lavado vaginal (Marcondes et al., 2002). O ciclo estral corresponde ao ciclo ovariano que é dividido em fase folicular e fase periovulatória.

1) Fase folicular: Compreende as fases diestro e metaestro. O ciclo ovariano inicia-se com o desenvolvimento de folículos de oócitos no ovário. Baixas concentrações de hormônio folículo-estimulante (FSH) da pituitária estimulam o desenvolvimento folicular. Há também aumento de esteroidogênese nessa fase, causada pela estimulação de hormônio luteinizante (LH). O nível de $17 \beta$-estradiol aumenta gradualmente nessa fase. No camundongo, tem a duração de 2 dias. O primeiro dia é chamado de metaestro, e o segundo dia de diestro.

2) Período periovulatório: Compreende a fase de proestro. O período antes e depois da ovulação é dinâmico. O $17 \beta$-estradiol aumenta rapidamente, agindo no cérebro para desencadear a liberação de hormônio liberador de gonadotrofina $(\mathrm{GnRH})$, que induz aumento de $\mathrm{LH}$ pela pituitária, que induz a ovulação. A progesterona aumenta algumas horas antes da ovulação e contribui para esse processo. No camundongo, essa fase é classificada como proestro (Becker et al., 2005). O 17ß-estradiol máximo liberado pelo ovário inicia-se 18 horas antes da ovulação e, no soro, os valores de $17 \beta$-estradiol podem alcançar o pico de 50 a 150 pg/ml, cerca de 6 a 12 horas antes da ovulação (Becker et al., 2005). Um significativo aumento de progesterona ocorre de 4 a 6 horas após o aumento de $17 \beta$-estradiol, 
durante a tarde de proestro. Uma vez que LH e progesterona são liberados para a circulação, a ovulação ocorre após 10-12 horas. Um aumento significativo da progesterona ocorre de 4 a6 horas após o aumento de $17 \beta$-estradiol, durante a tarde de proestro. A concentração de progesterona no soro, no pico de proestro, é de cerca $25-50 \mathrm{ng} / \mathrm{ml}$. Uma vez que o hormônio luteinizante $(\mathrm{LH})$ e a progesterona são liberados para a circulação, a ovulação ocorre de 10 a 12 horas mais tarde (Becker et al., 2005).

3) O estro é o período de receptividade sexual e o período da ovulação (Becker et al., 2005). O ciclo estral é um processo dinâmico com mudanças que ocorrem rapidamente, em especial durante o proestro e estro. A concentração basal de soro de $17 \beta$ - estradiol é de aproximadamente $3-12 \mathrm{pg} / \mathrm{ml}$.

O lavado vaginal é usado para determinar a fase do ciclo estral, que consiste de 4 estágios: metaestro, diestro, proestro e estro. Cada um desses estágios dura de 6 a 8 horas em metaestro, de 55 a 57 horas em diestro, de 12 a 14 horas em proestro e de 25 a 27 horas em estro, sendo que mudanças específicas dependem das espécies e da programação de claro escuro. A citologia vaginal não reflete imediatamente as mudanças na secreção hormonal, devido ao atraso existente entre a secreção hormonal e a alteração morfológica nas células-alvo vaginais.

O ciclo estral de ratas fêmeas é similar ao ciclo estral de camundongos fêmeas. A citologia do lavado vaginal reflete os eventos endócrinos e pode ser utilizada para identificar as fases do ciclo estral (Figura 4): 
- Proestro: O lavado vaginal de camundongo fêmea nessa fase é caracterizado por apresentar células epiteliais nucleares e algumas células cornificadas.

- Estro: Nessa fase, o lavado vaginal apresenta predominância de células epiteliais cornificadas.

- Metaestro: Nessa fase, há predominância de leucócitos, e poucas células epiteliais nucleares e/ou células epiteliais cornificadas.

- Diestro: Predominância de leucócitos no lavado vaginal de camundongos fêmeas. 


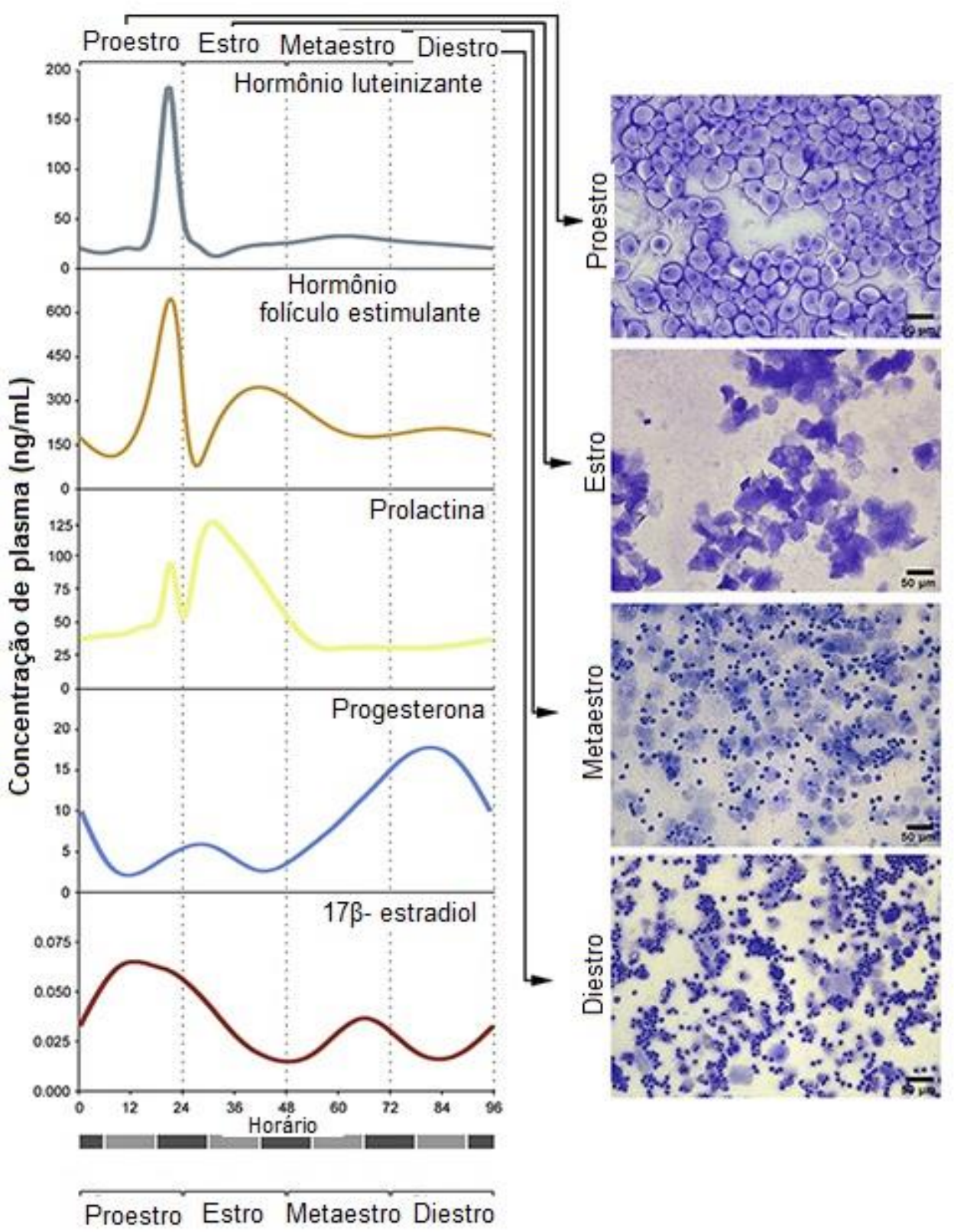

Figura 4. Citologia de lavado vaginal refletindo eventos endócrinos. Adaptado de Mc Lean et al. Jof Visualized Experiments. 2012; 67,1-6.

O papel direto dos hormônios gonadais em regiões não genitais, em atividades tróficas e no processamento sensorial não foi bem estudado. Um estudo mostrou alterações na citologia do epitélio nasal de acordo com a fase do ciclo menstrual, e as alterações nas células do epitélio nasal foram 
semelhantes às observadas nas amostras citológicas vaginais (Serra et al., 2004).

Uma hipótese levantada neste projeto seria a de que provavelmente o epitélio nasal sofreria os efeitos descritos, como a liberação endócrina causada pelos poluentes do ar, e que esses contaminantes no ar ambientes poderiam interagir com receptores para hormônios esteroides, como acontece in vitro e in vivo em outras regiões do organismo pelas partículas da exaustão de motores do tráfico (Clemons et al., 1998; Rudel et al., 2003; Kizu et al., 2003; Okamura et al., 2004; Wang et al., 2004; Wang et al., 2005b; Klein et al., 2006).

Nesse contexto, estudamos se a poluição do ar altera a expressão de receptores estrogênicos, seu competidor $A h R$ e enzimas de detoxificação (da família da enzima P450), bem como o perfil de muco expresso no epitélio da via aérea superior de camundongos machos e fêmeas em estro, proestro e diestro para verificarmos se esses parâmetros se alteram com a poluição e com a fase do ciclo estral das fêmeas e se estes se mantêm constante nos camundongos machos. Para tal, os animais foram submetidos à poluição por meio de um concentrador de partículas ambientais. Os animais machos e fêmeas, com 21 dias de idade, foram submetidos à exposição por um período igual ou superior a 45 dias. 
OBJETIVOS 


\section{Objetivos}

Os objetivos deste estudo foram:

- Verificar como a poluição, principalmente os hidrocarbonetos policíclicos aromáticos, relacionam-se com a expressão dos receptores de estrógeno e aril hidrocarbono $(A h R)$ e das enzimas detoxificantes da família do citocromo P450 (CYP1A1, 1B1 e 1A2) na mucosa das vias aéreas de camundongos machos e fêmeas em diferentes fases do ciclo estral;

- Avaliar o efeito da poluição sobre a produção de muco ácido e neutro no epitélio nasal de camundongos machos e fêmeas em diferentes fases do ciclo estral. 
MÉTODOS 


\section{Métodos}

\subsection{Comissão de Ética}

Este estudo foi aprovado pela Comissão de Ética em Pesquisa da Faculdade de Medicina da Universidade de São Paulo (CEP-FMUSP), sob o Protocolo de Pesquisa $n^{\circ}$ 178/10.

\subsection{Concentrador de partículas ambientais (CPA)}

O CPA é um equipamento instalado na Faculdade de Medicina da Universidade de São Paulo (FMUSP), entre a Avenida Doutor Arnaldo e a Rua Teodoro Sampaio, região com tráfego intenso de veículos automotores, além de apresentar um corredor de ônibus (Figura 5).

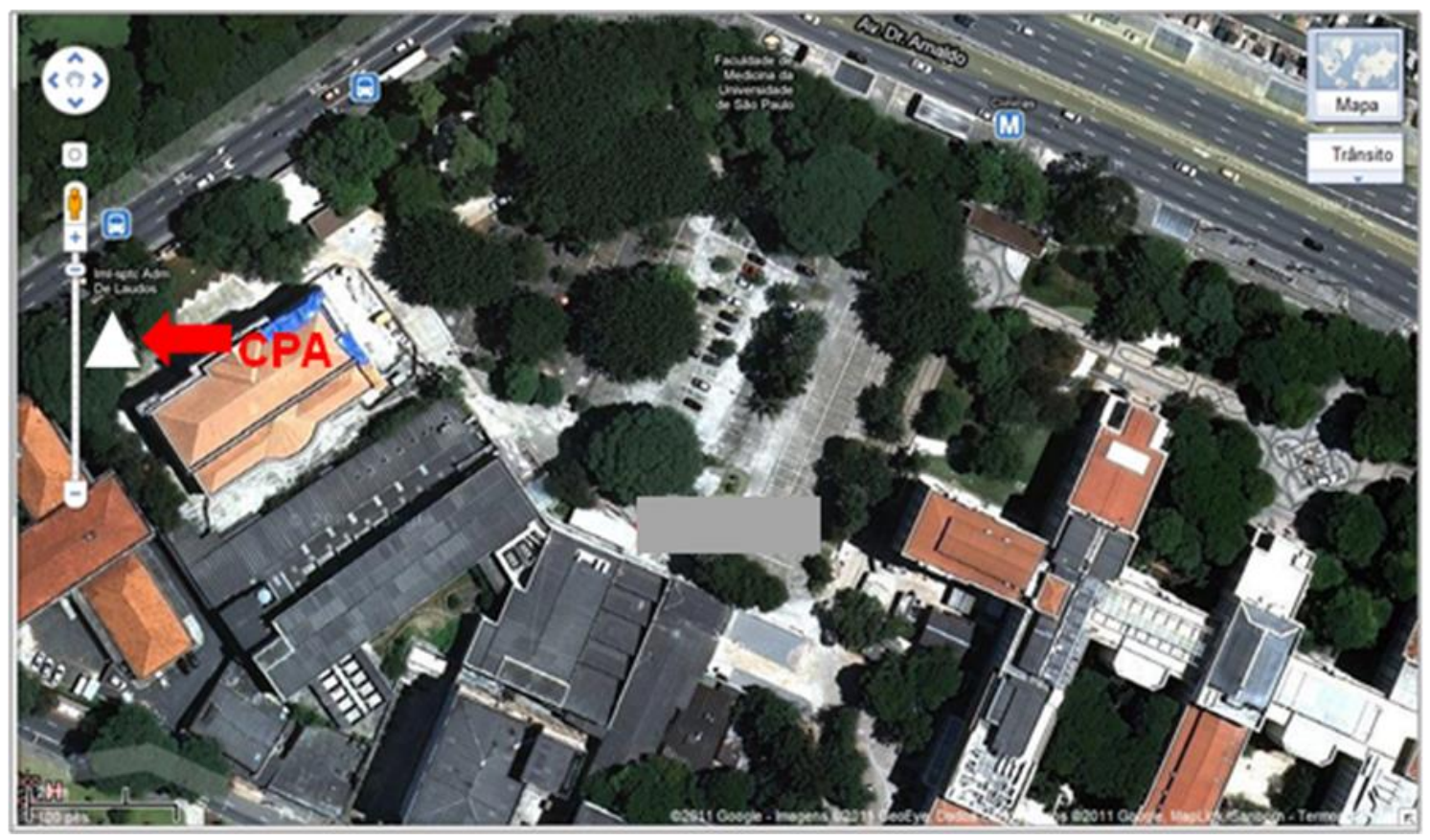

Figura 5. Vista superior do CPA localizado no pátio da FMUSP. 
Esse equipamento foi desenvolvido pela Escola de Saúde Pública de Harvard - EUA e utiliza a tecnologia de impactadores virtuais, com o propósito de concentrar em até 30 vezes as partículas ambientais presentes na atmosfera sem modificá-las química ou fisicamente. O CPA permite o controle da concentração à qual os animais serão expostos, possibilitando estudos de dose resposta. $\mathrm{O}$ ar, então carregando uma concentração determinada de partículas, alimenta uma câmara onde animais serão expostos. Ao mesmo tempo, e sob as mesmas condições de pressão, fluxo, temperatura e umidade relativa, outra câmara disposta paralelamente é alimentada com ar ambiente para exposição do grupo controle (Figura 6).

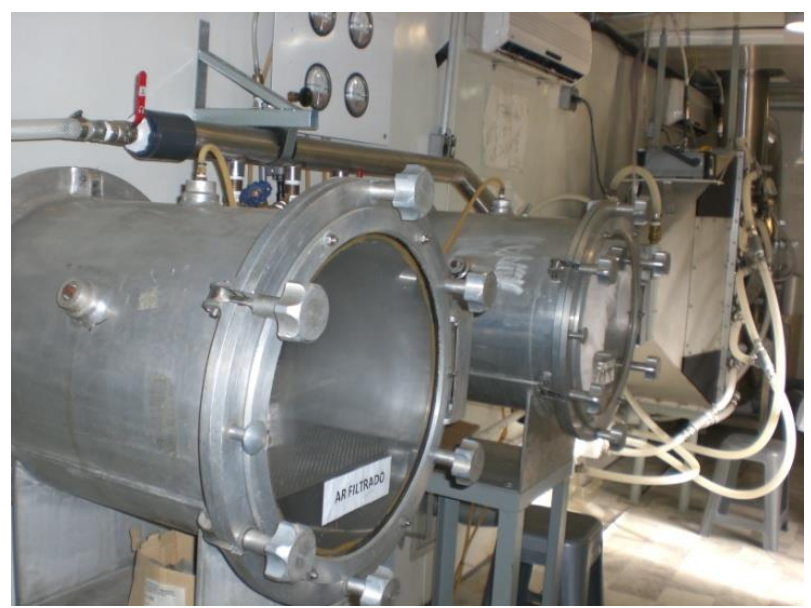

Figura 6. (1) Câmara de exposição com ar ambiente (2) câmara de exposição com material particulado de $2,5 \mu \mathrm{m}$ de diâmetro $\left(\mathrm{MP}_{2,5}\right)$ concentrado.

Em ambas as câmaras os animais são acondicionados em gaiolas apropriadas e estão livres para respirar naturalmente (Figura 7). Esse equipamento foi adquirido com verba FAPESP, projeto 2002/09804-0. 


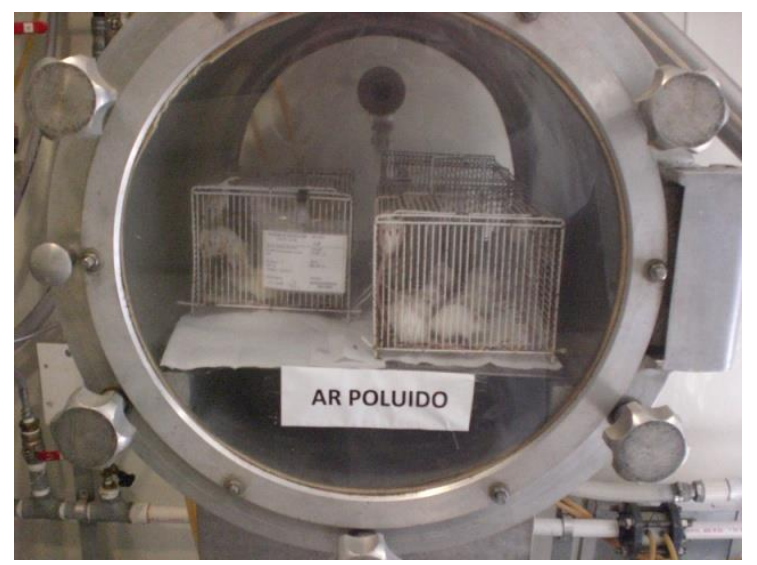

Figura 7. Vista interna da câmara de exposição mostrando os animais recebendo ar concentrado de partículas. Animais são acondicionados em gaiolas apropriadas e estão livres para respirar naturalmente.

A Figura 8 mostra o monitoramento durante o período de exposição dos camundongos $\mathrm{BALB} / \mathrm{c}$ no CPA: concentração de $\mathrm{MP}_{2,5}$, temperatura e umidade relativa (TrakPro versão 3.6.1.0, EUA).

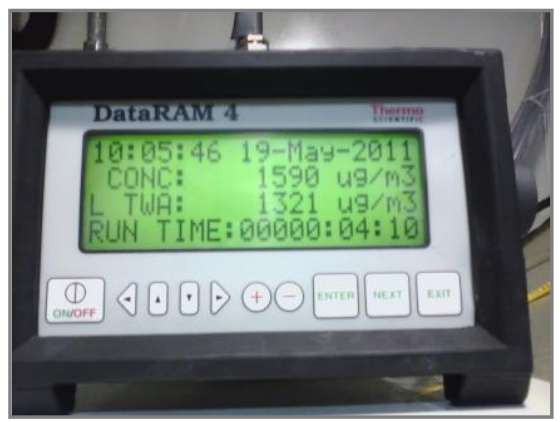

Figura 8. Sistema de monitoramento de $\mathrm{MP}_{2,5}$, temperatura e umidade relativa

Ao completarem o período de exposição (aproximadamente 45 dias), as fêmeas foram avaliadas quanto à ciclicidade estral.

\subsection{Amostragem para análise dos HPAs}


A extração e análise das amostras para a determinação dos HPAs foram realizadas no Instituto de Química da Universidade de São Paulo (IQ-USP).

\subsubsection{Preparação dos filtros}

O material particulado foi coletado em filtros de fibra de quartzo $(20 \times 25$ cm) apropriados para a coleta de amostras para análises de poluentes orgânicos.

Os filtros utilizados foram pesados antes e depois da coleta, obtendo-se, pela diferença entre as duas pesagens, a massa de material particulado. Nas análises foi utilizado um quarto de filtro para se seguir com o processo de extração e posterior identificação dos HPAs.

Os filtros foram protegidos com papel alumínio e embalagem plástica até serem levados ao equipamento de amostragem. Após a amostragem, o filtro foi retirado do aparelho e transportado em caixa térmica com gelo para resfriá-lo, e estocado a baixas temperaturas $\left( \pm-4^{\circ} \mathrm{C}\right)$ para evitar a perda de componentes voláteis.

\subsubsection{Coleta do Material Particulado}

Amostras de material particulado foram coletadas durante o período de 7 dias no mês de julho. O equipamento usado na coleta dos dados experimentais foi um amostrador de grande volume $\left(1,13 \mathrm{~m}^{3} / \mathrm{min}\right)$, com diâmetro de corte das partículas em 2,5 $\mu \mathrm{m}$ (Figura 9). Este amostrador permite a coleta de partículas menores que 2,5 $\mu \mathrm{m}\left(\mathrm{MP}_{2.5}\right)$. $\mathrm{O}$ amostrador foi instalado próximo ao container do CPA onde os animais são expostos ao material particulado. A amostragem do $\mathrm{MP}_{2.5}$ foi conduzida por um período continuo de 24 horas em todas as amostras coletadas. 


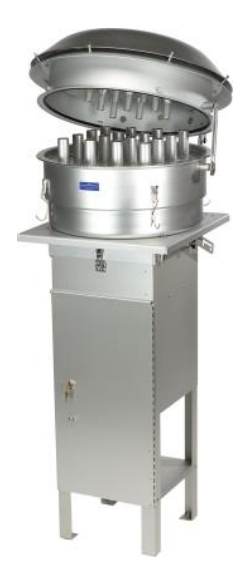

Figura 9. Amostrador de grande volume

\subsubsection{Extração e análise das amostras}

Cada amostra coletada foi extraída com diclorometano em banho de ultrassom por 20 minutos, sendo esta extração repetida três vezes, usando-se $80 \mathrm{~mL}$ de solvente em cada vez. O extrato foi então concentrado por rotaevaporação até redução à aproximadamente $2 \mathrm{~mL}$ de material. A coluna de fracionamento para obtenção de classes diferentes de compostos foi preenchida com lã de vidro, 3,2 g de sílica gel 6\% ativada, e 1,8 $\mathrm{g}$ de alumina $5 \%$ ativada.

Cada coluna, depois de adicionada à amostra, foi eluída com duas soluções, recolhendo-se a fração respectiva de cada eluição. A primeira solução foi de $40 \mathrm{~mL}$ de $n$-hexano (não analisada neste trabalho), e a segunda de 1:1 de diclorometano e $n$-hexano. A fração resultante da primeira eluição contém os $n$-alcanos e a da segunda contém os HPAs. Esta última foi analisada por cromatografia a gás (Agilent Technologies - modelo 7820A) e detecção por espectrometria de massas (Agilent Technologies - modelo 5975series MSD) (CG/EM) (Karavalakis et al., 2010). 
As condições da cromatografia foram: as temperaturas de injeção e de detecção são, respectivamente, 40 e $310^{\circ} \mathrm{C}$; rampa de temperatura: $40^{\circ} \mathrm{C}$ por 1 minuto, $100^{\circ} \mathrm{C}$ por 5 minutos, $210^{\circ} \mathrm{C}$ aumentando $10^{\circ} \mathrm{C}$ por minuto, até atingir $310^{\circ} \mathrm{C}$, mantidos por 45 minutos. $\mathrm{O}$ gás de arraste foi o hélio.

Para a análise por CG/MS foram elaboradas curvas-padrão para cada composto, utilizando-se soluções nas concentrações: 1, 2, 5, 7 e 10 ppm.

\subsection{Protocolo de exposição}

Foram utilizados como bioindicadores dos efeitos da exposição ao material particulado sobre a receptividade de estrógeno na via aérea 84 camundongos fêmeas e 32 machos da linhagem $B A L B / c$ adultos jovens, que tiveram início à exposição aos 21 dias de idade, pesando aproximadamente 18g. Os animais foram fornecidos pelo Biotério da FMUSP e mantidos durante o desenvolvimento do trabalho em nosso biotério de manutenção para roedores, com climatização e ciclo de luz dentro das normas preconizadas. Dentre essas normas, destacamos o número limitado a cinco animais por gaiola, limpeza e troca de gaiolas e bebedouros, na frequência de três vezes por semana, e alimentação administrada com ração comercial balanceada (Nuvital-Nutrients Ltda., Colombo, Brasil) e água "ad libitum".

As exposições tiveram início em março e maio de 2011. Antes das exposições, os animais passaram por um período de adaptação de 2 dias no biotério. Os animais foram expostos diariamente (5 dias por semana) no período que compreendia o final da manhã e começo da tarde. Um grupo recebeu material particulado concentrado com 2,5 $\mu \mathrm{m}$ de diâmetro $\left(\mathrm{MP}_{2,5}\right)$, 
numa concentração total de $600 \mu \mathrm{g} \cdot \mathrm{m}^{-3}$, que representa a concentração do ambiente na cidade de São Paulo (CETESB, 2012). Outro grupo recebeu ar ambiente (A) com o auxílio do concentrador de partículas ambientais (CPA).

\subsection{Grupos Experimentais}

Os animais foram divididos em oito grupos de acordo com a exposição e ciclo estral:

Grupo 1: Camundongos machos expostos ao ar ambiente (M/AA).

Grupo 2: Camundongos machos expostos ao CPA (M/MP).

Grupo 3: Camundongos fêmeas na fase proestro expostas ao ar ambiente (PE/AA).

Grupo 4: Camundongos fêmeas na fase proestro que foram expostas ao CPA (PE/MP)

Grupo 5: Camundongos fêmeas na fase estro expostas ao ar ambiente (E/AA).

Grupo 6: Camundongos fêmeas na fase estro expostas ao CPA (E/MP).

Grupo 7: Camundongos fêmeas na fase diestro expostas ao ar ambiente (D/AA).

Grupo 8: Camundongos fêmeas na fase diestro expostas ao CPA (D/MP).

\subsection{Avaliação do ciclo estral}

Para a verificação de alterações na ciclicidade estral, as fêmeas foram submetidas à coleta de lavados vaginais diários durante um período de duas semanas, o que nos fornece dados sobre 3 ciclos, considerando ciclos normais 
de 4 dias (Morissey et al., 1988a; 1988b). Os lavados vaginais foram coletados em lâminas e corados, seguindo protocolo laboratorial abaixo mencionado.

As lâminas foram secas e lavadas em álcool $95^{\circ}$ para fixação, em seguida lavadas em álcool $70^{\circ}$, e rapidamente em água corrente, sendo, então, coradas com Hematoxilina permanecendo por 3 minutos, e então, lavadas em água corrente e álcool $90^{\circ}$. Em seguida foram coradas com Shorr por 5 minutos e lavadas em álcool 95

Os lavados vaginais foram avaliados por microscopia de luz para classificação do estágio do ciclo com base na preponderância de células epiteliais cornificadas, células epiteliais nucleadas e leucócitos.

O ciclo estral de camundongos fêmeas (Figura 10) foi determinado pelos tipos celulares observados no lavado vaginal:

- Proestro: os ovários são estimulados pelos hormônios FSH e LH, secretados pela hipófise, produzindo quantidades crescentes de estrogenos. Observam-se células espiteliais nucleares e algumas células cornificadas.

- Estro: fase em que termina a maturação folicular e ocorre a ovulação. Elevadas concentrações de estrogéneo. Observam-se células epiteliais cornificadas.

- Diestro: Ocorre caso não haja fecundação, e, ao fim do Diestro, o animal

- irá entrar em novo ciclo estral. Predominantemente leucócitos. 

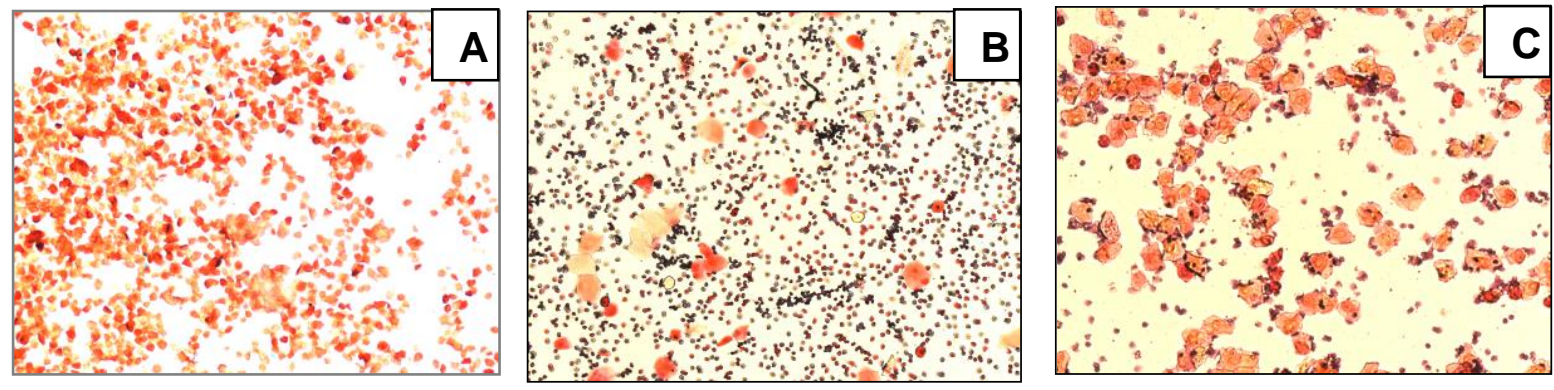

Figura 10. Ciclo estral: (A) estro, (B) diestro, (C) proestro. Fotomicrografia A (50x), B e C(100x).

\subsection{Coleta e análise do tecido nasal}

Após 24 horas do término da última exposição e verificação do ciclo estral, os animais foram anestesiados com ketamina (50 mg/ $\mathrm{Kg}$ ) e xilazina (40 $\mathrm{mg} / \mathrm{Kg}$ ) e eutanasiados por secção da aorta abdominal e exsanguinação.

Para a análise histológica a cabeça foi removida, a mandíbula desarticulada, colocada em formol tamponado por 24 horas, e depois colocada em solução com EDTA para descalcificação. Ao término da descalcificação, a cavidade nasal foi dividida por meio de secção transversal para análise da região medial com o ponto de corte próximo à papila incisiva, anteriormente ao palato duro (Figura 11). Essa técnica, com este nível de corte, permite examinar melhor as células epiteliais na cavidade nasal (septo nasal) e interpretar a mudança após a intoxicação (Herbert, Leininger, 1999; CamargoPires Neto et al., 2006; Yoshizaki et al., 2010). 

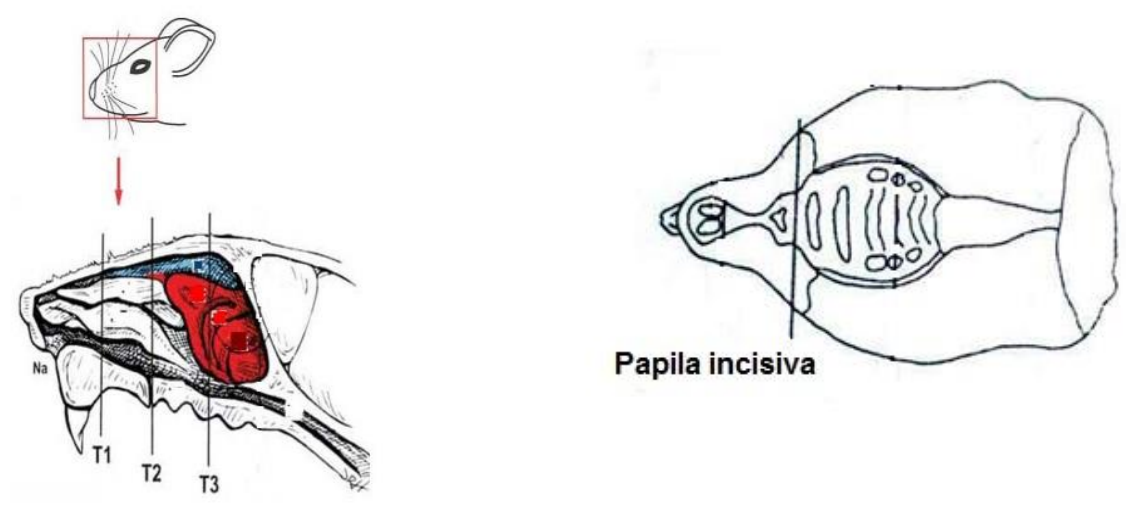

Figura 11. Ilustração da superfície ventral e lateral do crânio de camundongo evidenciando a estrutura utilizada para marcar o "ponto de corte" da cavidade nasal (adaptado de Herbert; Leininger, 1999).

As amostras foram embebidas em parafina e processadas de acordo com a rotina histológica. Cortes de $5 \mu \mathrm{m}$ de espessura foram obtidos ao nível da cavidade nasal estudada.

Para a análise de expressão gênica do epitélio nasal, após a remoção cirúrgica da cabeça, um corte longitudinal foi realizado para exposição do septo nasal para coleta do tecido epitelial nasal. O tecido epitelial nasal foi armazenado em tubos "eppendorf" com $200 \mu$ l de RNA later para procedimento de extração de RNA.

\subsection{Extração de RNA total e Transcrição Reversa (RT)}

Essa parte do trabalho foi realizada no Laboratório de Biologia Molecular da Tireoide no Instituto de Ciências Biomédicas (ICB-USP).

Extração de RNA total e Transcrição Reversa (RT): o RNA total foi extraído das células com base na técnica desenvolvida por Chomczynski e 
Sacchi (1987), utilizando o reagente $\operatorname{TRIzo}^{\circledR}$ (Invitrogen Life Technologies), conforme instruções do fabricante. O DNA complementar (cDNA) foi sintetizado utilizando-se $1 \mu \mathrm{g}$ de RNA total, e incubado na presença de $1 \mu \mathrm{L}$ Oligo dT (Invitrogen Life Technologies), $1 \mu \mathrm{L}$ de inibidor de RNase (Recombinant RNase Inhibitor, Invitrogen), $1 \mu \mathrm{L}$ de cada deoxinucleotídeo trifosfatado (Invitrogen Life Technologies) e $1 \mu \mathrm{L}$ de enzima Transcriptase Reversa (MultiScribe) (Applied Biosystems, Califórnia, EUA). A reação foi realizada a $21^{\circ} \mathrm{C}$ por 10 minutos, a $42^{\circ} \mathrm{C}$ por 30 minutos, e a $99^{\circ} \mathrm{C}$ por 10 minutos em termociclador Cyclogene (Thecne, Inglaterra).

\subsection{PCR quantitativo em tempo real}

Esse método foi utilizado para determinar a expressão do gene $E r \beta, A h r$, Cyp1a1, Cyp1a2, Cyp1b1 com a utilização do fluoróforo $S Y B R^{\circledR}$ Green. Essa metodologia baseia-se na intercalação do $S Y B R^{\circledR}$ Green na dupla fita de DNA e no monitoramento da fluorescência emitida em cada ciclo da amplificação. Porém, o fluoróforo pode ligar-se a qualquer dupla fita formada durante a reação, incluindo dímeros de oligonucleotídeos (Ririe et al., 1997). Portanto, a especificidade da reação é verificada por meio de uma curva de desnaturação que eleva a temperatura até que ocorra a desnaturação completa do produto da PCR, onde um único pico de fluorescência é indicativo de uma reação específica.

Nas reações foram utilizadas 50 ng de cDNA, primers específicos que anelam em éxons distintos (Tabela 1) e SYBR Green PCR Master Mix (Applied 
Biosystems, Califórnia, EUA) no termociclador ABI Prism ${ }^{\circledR} 7300$ Sequence Detection System (Applied Biosystems) nas seguintes condições: $50^{\circ} \mathrm{C}$ por 2 minutos, $95^{\circ} \mathrm{C}$ por 10 minutos, 40 ciclos de $95^{\circ} \mathrm{C}$ por 15 segundos e $60^{\circ} \mathrm{C}$ por um minuto.

Tabela 1. Sequências de primes estudados neste trabalho.

\begin{tabular}{cll}
\hline Gene & \multicolumn{1}{c}{ Sequência de primers } \\
\hline \multirow{2}{*}{ Cyp1a1 } & $\begin{array}{l}\text { sense } \\
\text { antisense }\end{array}$ & 5'- CCTTCCGGCATTCATCCTT- 3' \\
& $\begin{array}{l}\text { sense } \\
\text { Cyp1a2 }\end{array}$ & 5'- TCAATGATAACTTCGTGCTGTTCT-3' \\
& antisense & 5'- TTGTGATGTCTTGGATACTGTTCTTG-3' \\
Erß-1 & sense & 5'- CTCGTTCTGGACAGGTCCTC-3' \\
& antisense & 5'- CAGAATCCCTTCCACGCACT-3' \\
Erß-2 & sense & 5'- TCAGCCTGTTGGACCAAGTC-3' \\
& antisense & 5'- CCTCATCCCTGTCCAGAACG-3' \\
Ahr & sense & 5'- TCCCACATCCGCATGATTAA-3' \\
& antisense & 5'- ATGATGTAATCTGGTCTCCATTCTG-3' \\
B-actina & sense & 5'- CAGCTTCTTTGCAGCTCCTT-3' \\
& antisense & 5'- CACGATGGAGGGGAATACAG-3' \\
\hline
\end{tabular}

A expressão gênica foi calculada a partir dos valores de threshold cycle, em que se avalia o número de ciclos necessários para que o sinal de fluorescência atinja o valor determinado.

A especificidade da reação foi avaliada através da análise da dissociação do produto amplificado. O programa Q-gene foi utilizado para a análise dos dados obtidos e a expressão gênica foi normalizada com o gene $\beta$ actina (Simon, 2003).

\subsection{Imuno-histoquímica}


Para a imuno-histoquímica, cortes histológicos do septo de epitélio nasal em lâminas silanizadas (3-Aminopropil-trietoxi-silano-Sigma) foram desparafinizados e hidratados, seguindo-se o protocolo descrito a seguir.

\subsubsection{Hidratação e Bloqueio}

Após a hidratação foram feitos o bloqueio da peroxidase endógena com água oxigenada $\left(\mathrm{H}_{2} \mathrm{O}_{2}\right) \quad 10 \mathrm{~V} 3 \% 7$ vezes de 5 minutos cada, e a lavagem com água e PBS.

\subsubsection{Recuperação antigênica}

A recuperação antigênica foi realizada com tampão citrato $(\mathrm{pH}=6)$ em temperatura alta. Em seguida, as lâminas foram resfriadas por 20 minutos e lavadas em PBS.

\subsubsection{Incubação com o anticorpo primário}

Após o bloqueio, seguiu-se a incubação com os anticorpos primários anti-AhR ((M-20) SC-8089, Sta.Cruz Biotechnology, Ca, USA) e anti-ERß ((H50) SC-8974, Sta.Cruz Biotechnology, Ca, USA), diluídos em BSA na proporção de 1:50 (Ahr), 1:400 (ERß), os quais foram aplicados sobre os cortes relativos ao experimento e controles (positivo e negativo) de tecido, e as lâminas foram incubadas durante a noite.

As lâminas foram então lavadas em PBS e incubadas com o anticorpo secundário que contém o sistema HRP (DakoCytomation K0690). Após essa

etapa, estas foram lavadas em PBS e, após a revelação pelo cromógeno 3,3 Diaminobenzidine (DAB) (Sigma Chemical Co, St Louis, MO, EUA), foram 
lavadas abundantemente em água corrente e contra-coradas com hematoxilina de Harris (Merck, Darmstadt, Alemanha). Em seguida, foram lavadas em água corrente, desidratadas, diafanizadas e montadas com resina para microscopia Entellan (Merck, Darmstadt, Alemanha).

\subsection{Quantificação da expressão ERbeta e Ahr no epitélio nasal}

Para cada animal, cortes transversais do epitélio nasal foram utilizados para a quantificação. Usando um microscópio Leica DMR acoplado a uma câmera de vídeo (JVC TK-C 1380) e a um sistema de análise de imagem (Image Pro-Plus 4.1, Media Cybernetics, Silver Spring, Md., USA), digitalizamos a imagem microscópica captada por um vídeo de alta resolução e acoplado a uma grade ocular de área conhecida. Foram avaliados 10 campos do epitélio nasal em um aumento de 1380X.

A área para a avaliação da expressão de Ahr e ERß, do epitélio nasal foi calculada a partir da área positiva dividida pela área total analisada no epitélio. Os resultados foram expressos como área positiva para Ahr e ERß, sobre área total analisada.

\subsection{Quantificação de muco neutro e ácido no epitélio nasal}

Lâminas foram preparadas e coradas com ácido periódico de Schiff e azul alciano (PAS/AB) com um $\mathrm{pH}$ de 2,5. Por meio dessa técnica, as glicoproteínas neutras e ácidas são coradas em vermelha e azul 
respectivamente (Jones; Reid, 1978). O conteúdo do muco (ácido ou neutro) do epitélio respiratório da cavidade nasal foi quantificado por morfometria convencional. As imagens microscópicas foram digitalizadas por meio de um microscópio Leica DMR acoplado a uma câmera de vídeo (JVC TK-C 1380) e a um sistema de análise de imagem (Image Pro-Plus 4.1, Media Cybernetics, Silver Spring, Md., USA). Para a contagem de pontos nas imagens digitalizadas foi acoplada uma grade de área conhecida $\left(11,47 \mu \mathrm{m}^{2}\right.$ de magnificação de 1380x). O número de pontos de cada tipo de muco e a área não secretora do epitélio foram contados em cada amostra, e o volume da proporção de muco neutro e ácido no epitélio respiratório foi determinado por contagem de pontos (Pires-Neto et al., 2006; Yoshizaki et al., 2010). Calculamos o número de pontos correspondentes à área total do tecido epitelial de cada amostra. $\mathrm{O}$ cálculo utilizado para quantificar o conteúdo do muco foi o seguinte:

(pontos de interesse / pontos totais X 11,47 $\mu \mathrm{m}^{2}$ )

média da espessura $(\mu \mathrm{m}) \mathrm{X}$ comprimento da membrana basal $(\mu \mathrm{m})$

\subsection{Quantificação da espessura do epitélio nasal}

A espessura média do epitélio nasal foi determinada por meio da distância entre o limite da membrana basal e o limite de membrana apical (magnificação de 1380x). Para cada valor medido para cada um dos cinco campos do epitélio foi utilizada uma média para proporcionar um único ponto de dados para cada animal. 


\subsection{Análise Estatística}

Os dados considerados paramétricos foram expressos em média e desvio padrão. Foram utilizados Test-T para comparação 2 a 2 e análise de variância (ANOVA) para comparação entre ciclos estrais. Os dados não paramétricos foram expressos em mediana e intervalo interquartil para comparar diferenças entre exposição e gênero (machos expostos ao ar ambiente, machos expostos ao CPA, fêmeas expostas ao ar ambiente, fêmeas expostas ao CPA). O teste Mann Whitney Rank Sum foi usado para comparar essas diferenças. Para comparar diferenças entre ciclos estrais das fêmeas o teste Kruskal-Wallis One Way Analysis of Variance on Ranks foi utilizado. Os dados foram analisados por meio do programa de análise SPSS v.21.0, SPSS Inc. ${ }^{\circledR}$, Chicago. O nível de significância considerado é $p<0,05$. 
RESULTADOS 


\section{Resultados}

\subsection{Análise dos poluentes atmosféricos:}

A concentração média de $\mathrm{MP}_{2,5}$ no $\mathrm{CPA}$ dos grupos expostos foi: $589,96 \mu \mathrm{g} / \mathrm{m}^{3}$, equivalente a uma concentração média diária de $24,58 \mu \mathrm{g} / \mathrm{m}^{3}$. Os níveis de MP estão dentro dos valores recomendado pela OMS de $25 \mu \mathrm{g} / \mathrm{m}^{3}$ em 24 horas (2005).

\subsection{Determinação dos HPAs}

As concentrações médias dos hidrocarbonetos nas amostras analisadas são apresentadas na Figura 12.

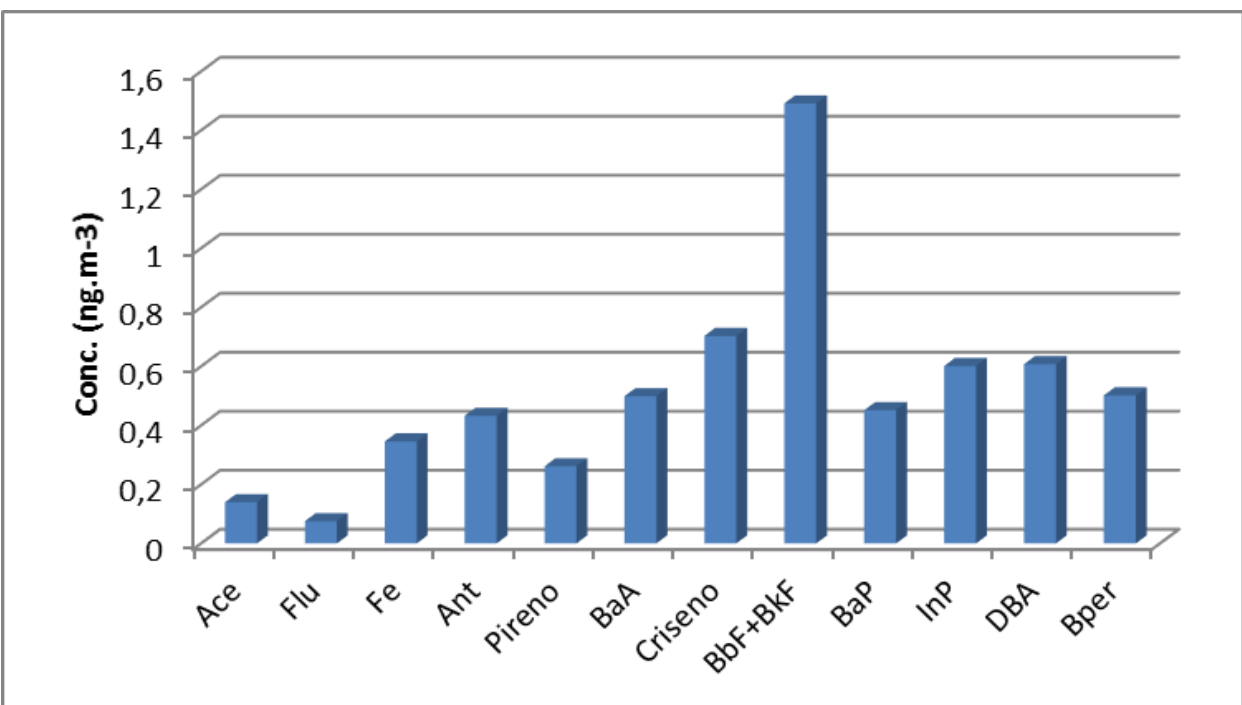

Figura 12. Concentrações médias dos hidrocarbonetos $\left(\mathrm{ng} / \mathrm{m}^{3}\right)$ para as amostras coletas próximas à exposição dos animais. Ace (acenafteno), Flu (fluoreno), Fe (fenantreno), Ant (antraceno), Pireno, BaA (benzo(a)antraceno), Criseno, BbF+BkF (benzo(b)fluoranteno e benzo(k)fluoranteno), BaP (benzo(a)pireno), InP (indeno(1,2,3cd)pireno), DBA (dibenzo antraceno), Bper (benzo(g,h,i)perileno). 
A Tabela 2 expõe as condições dos HPAs representados em média e desvio padrão.

Tabela 2. Caracterização e concentrações médias dos HPAs $\left(\mathrm{ng} / \mathrm{m}^{3}\right)$ para as amostras coletas.

\begin{tabular}{lc}
\hline HPA & Média \pm DP \\
\hline Acenafteno & $0,140 \pm 0,0292$ \\
Fluoreno & $0,076 \pm 0,0241$ \\
Fenantreno & $0,346 \pm 0,1085$ \\
Antraceno & $0,433 \pm 0,3751$ \\
Pireno & $0,262 \pm 0,2862$ \\
Benzo(a)antraceno & $0,499 \pm 0,8099$ \\
Criseno & $0,703 \pm 1,045$ \\
Benzo(b)fluoranteno e & $1,491 \pm 1,4861$ \\
benzo(k)fluoranteno & $0,452 \pm 0,54$ \\
Benzo(a)pireno & $0,601 \pm 0,5358$ \\
Indeno(1,2,3-cd)pireno & $0,608 \pm 0,7542$ \\
Dibenzo antraceno & $0,502 \pm 0,2849$ \\
Benzo(g,h,i)perileno & \\
Total HPA & 6,112 \\
\hline DP: Desvio padrăo
\end{tabular}

DP: Desvio padrão

\subsection{Análise do RNAm}

O epitélio nasal de camundongos machos e fêmeas expostos ao ar ambiente e a $\mathrm{MP}_{2,5}$ concentrado a $600 \mu \mathrm{g} / \mathrm{m}^{3}$ no CPAs foi processado para a extração de RNAm e PCR em tempo real para determinar a expressão gênica de Cyp1a1, Cyp1a2, Cyp1b1, Erß-1, Erß-2, Ahr.

Não houve diferença estatística significativa na expressão gênica de Cyp1a1 no epitélio nasal entre os camundongos machos e fêmeas (Figura 13), e entre as 3 fases do ciclo estral (proestro, estro e diestro) de camundongos 
fêmeas (Figura 14), após exposição subcrônica ao ar ambiente e $\mathrm{MP}_{2,5}$ concentrado a $600 \mu \mathrm{g} / \mathrm{m}^{3}$ no CPA.

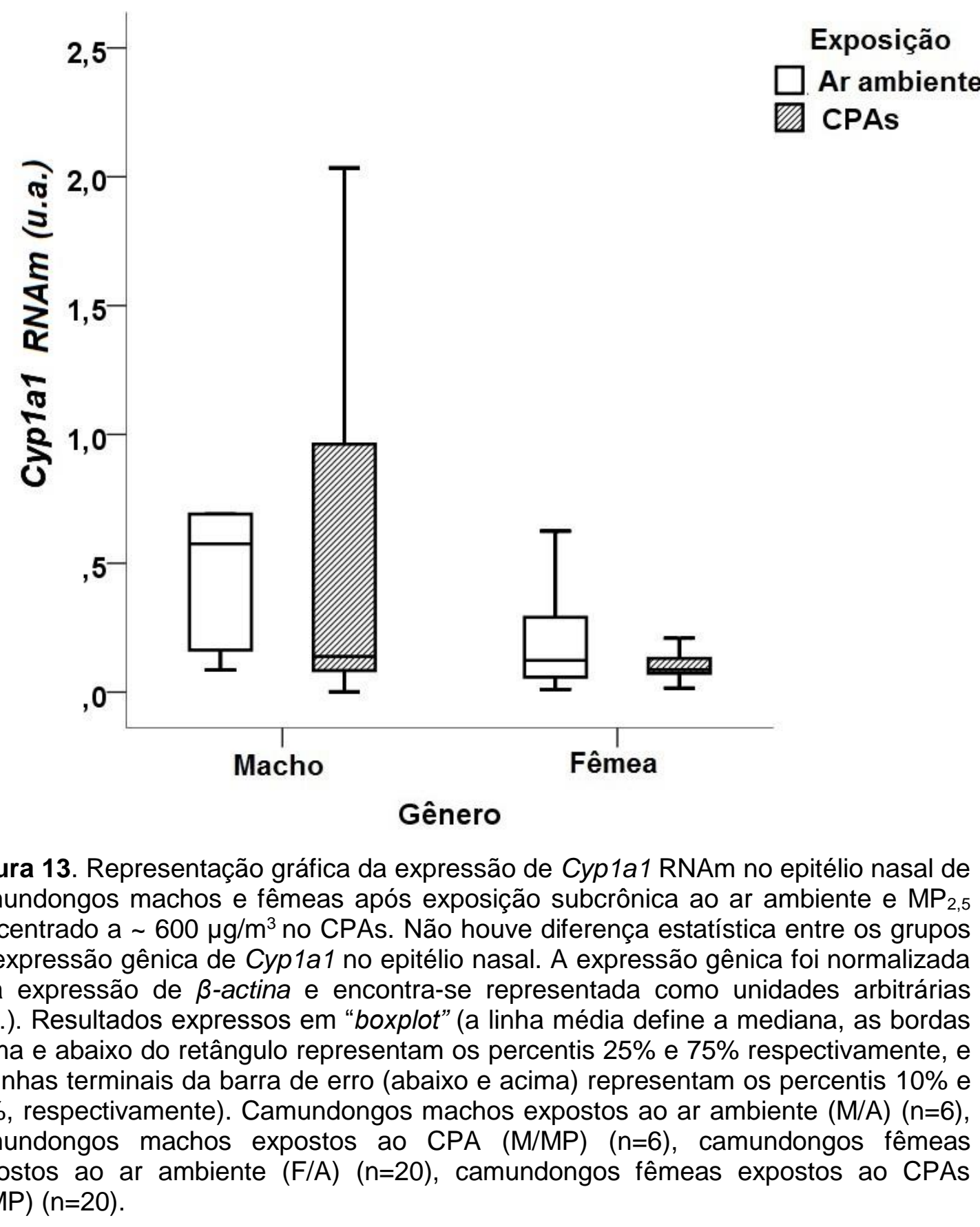

Figura 13. Representação gráfica da expressão de Cyp1a1 RNAm no epitélio nasal de camundongos machos e fêmeas após exposição subcrônica ao ar ambiente e $\mathrm{MP}_{2,5}$ concentrado a $600 \mu \mathrm{g} / \mathrm{m}^{3}$ no CPAs. Não houve diferença estatística entre os grupos na expressão gênica de Cyp1a1 no epitélio nasal. A expressão gênica foi normalizada pela expressão de $\beta$-actina e encontra-se representada como unidades arbitrárias (u.a.). Resultados expressos em "boxplot" (a linha média define a mediana, as bordas acima e abaixo do retângulo representam os percentis $25 \%$ e $75 \%$ respectivamente, e as linhas terminais da barra de erro (abaixo e acima) representam os percentis $10 \%$ e $90 \%$, respectivamente). Camundongos machos expostos ao ar ambiente $(M / A)(n=6)$, camundongos machos expostos ao CPA (M/MP) ( $n=6)$, camundongos fêmeas expostos ao ar ambiente ( $F / A)(n=20)$, camundongos fêmeas expostos ao CPAs $(F / M P)(n=20)$. 


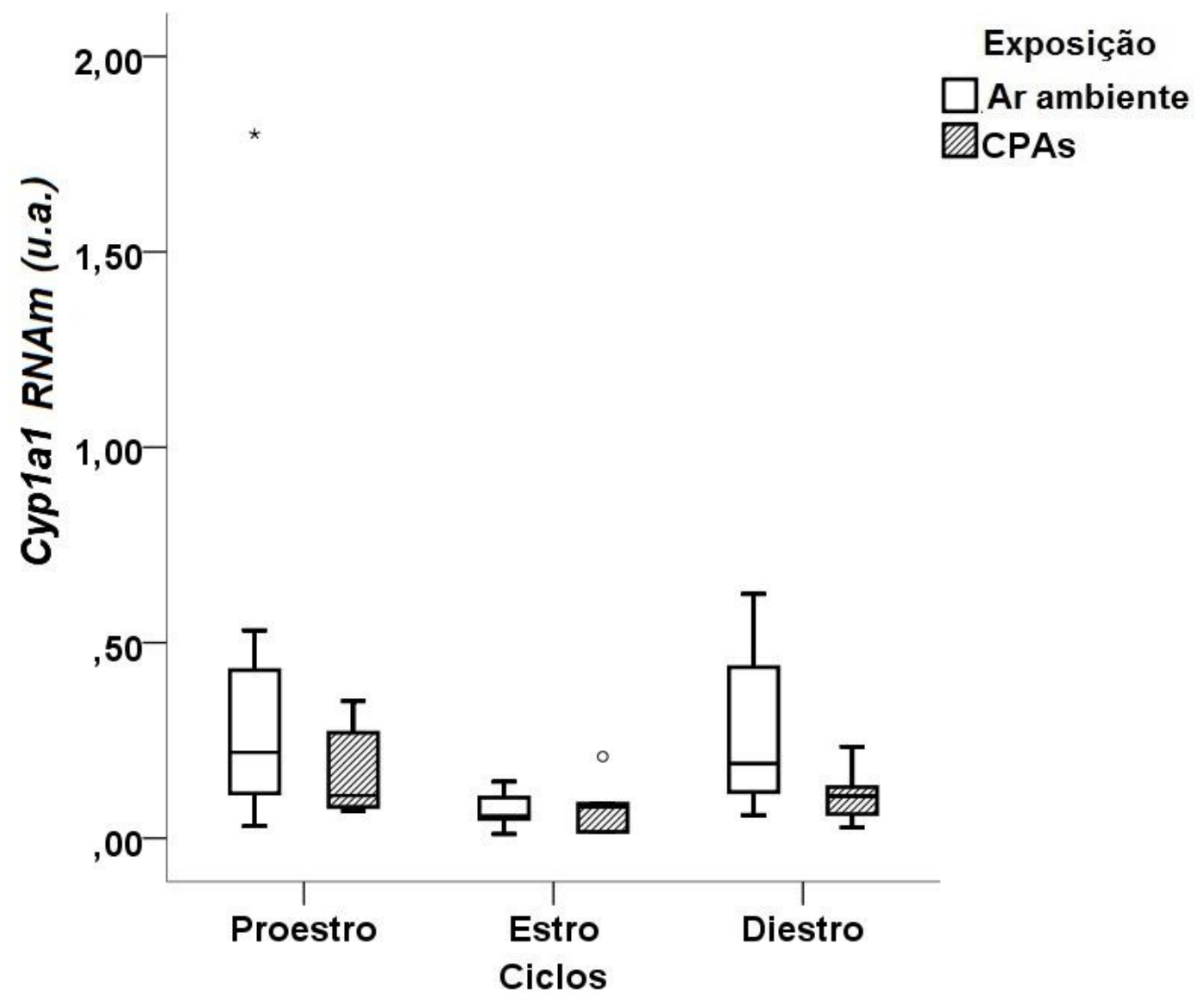

Figura 14. Representação gráfica da expressão de Cyp1a1 RNAm no epitélio nasal de camundongos fêmeas em 3 fases do ciclo estral (proestro, estro e diestro) após exposição subcrônica ao ar ambiente e $\mathrm{MP}_{2,5}$ concentrado a $~ 600 \mu \mathrm{g} / \mathrm{m}^{3}$ no CPAs. Não houve diferença estatística entre os grupos na expressão gênica de Cyp1a1 no epitélio nasal. A expressão gênica foi normalizada pela expressão de $\beta$-actina e encontra-se representada como unidades arbitrárias (u.a.). Valores expressos em "boxplot" (a linha média define a mediana, as bordas acima e abaixo do retângulo representam os percentis $25 \%$ e $75 \%$ respectivamente, e as linhas terminais da barra de erro (abaixo e acima) representam os percentis 10\% e $90 \%$, respectivamente). Camundongos fêmeas nas seguintes fases: proestro, que foram expostas ao ar ambiente (PE/A) $(n=7)$; proestro, expostos ao CPA (PE/MP) $(n=6)$; estro, expostos ao ar ambiente (E/A) ( $n=7)$; estro, expostos ao CPA (E/MP) $(n=6)$; diestro, expostos ao ar ambiente $(D / A)(n=6)$, e diestro, expostos ao CPAs (D/MP) $(n=8)$. 
A expressão gênica de Cyp1a2 no epitélio nasal de camundongos machos e fêmeas não apresentou diferença estatística significativa (Figura 15).

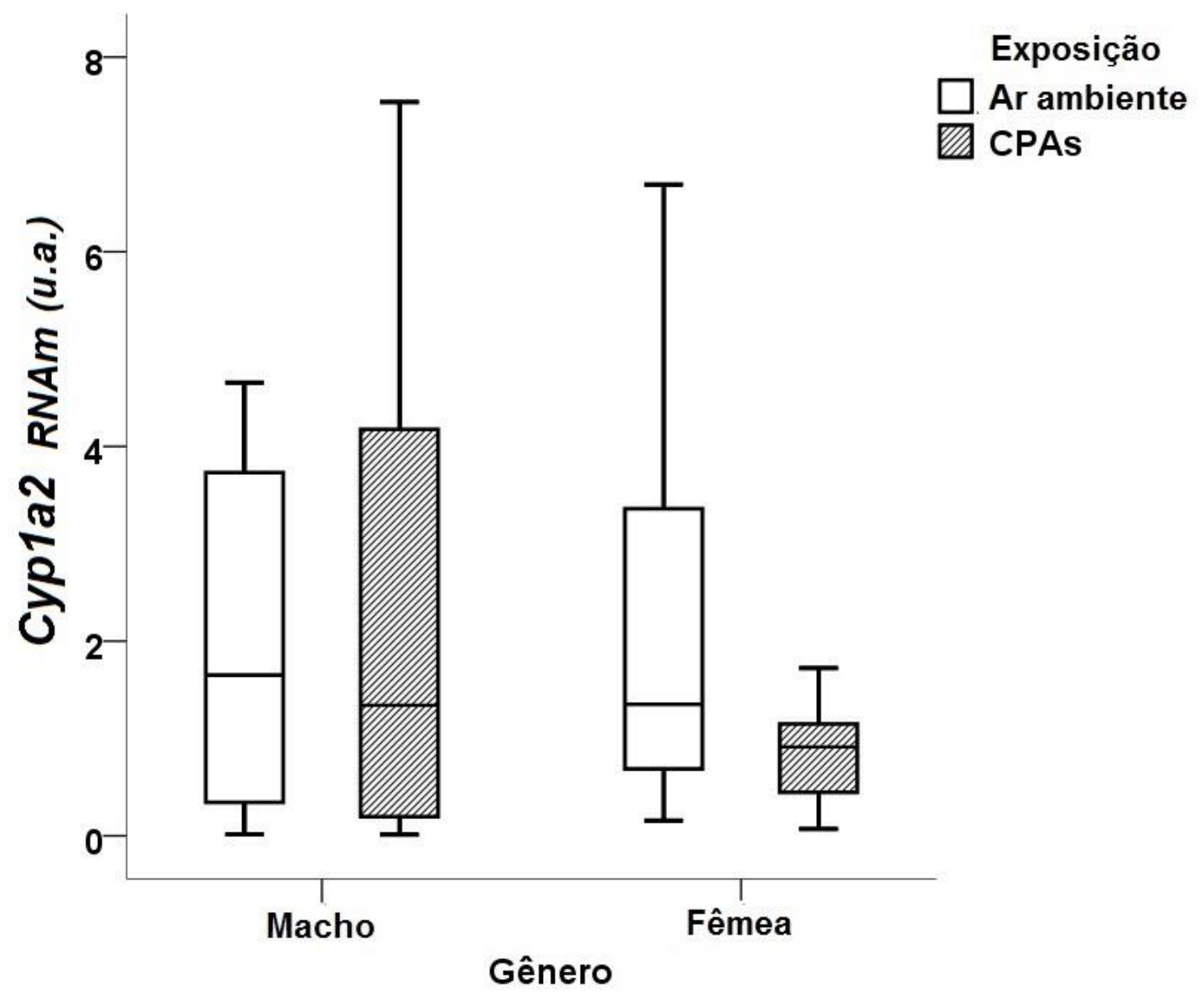

Figura 15. Representação gráfica da expressão de Cyp1a2 RNAm no epitélio nasal de camundongos machos e fêmeas após exposição subcrônica ao ar ambiente e $\mathrm{MP}_{2,5}$ concentrado a $600 \mu \mathrm{g} / \mathrm{m}^{3}$ no CPAs. Não houve diferença estatística entre os grupos na expressão gênica de Cyp1a2 no epitélio nasal. A expressão gênica foi normalizada pela expressão de $\beta$-actina e encontra-se representada como unidades arbitrárias (u.a.). Valores expressos em "boxplot" (a linha média define a mediana, as bordas acima e abaixo do retângulo representam os percentis $25 \%$ e $75 \%$ respectivamente, e as linhas terminais da barra de erro (abaixo e acima) representam os percentis $10 \%$ e $90 \%$, respectivamente). Camundongos machos expostos ao ar ambiente $(M / A)(n=8)$, camundongos machos expostos ao CPA (M/MP) ( $n=6)$, camundongos fêmeas expostos ao ar ambiente ( $F / A)(n=20)$, camundongos fêmeas expostos ao CPA (F/MP) $(n=21)$. 
Entretanto, entre as fases do ciclo estral das fêmeas observou-se, na fase diestro, uma diminuição da expressão gênica de Cyp1a2 no grupo exposto ao CPA quando comparado ao grupo exposto ao ar ambiente. Além disso, a expressão gênica de fêmeas em proestro e estro é significantemente diferente quando comparadas na exposição ao ar ambiente e ao CPA (Figura 16).

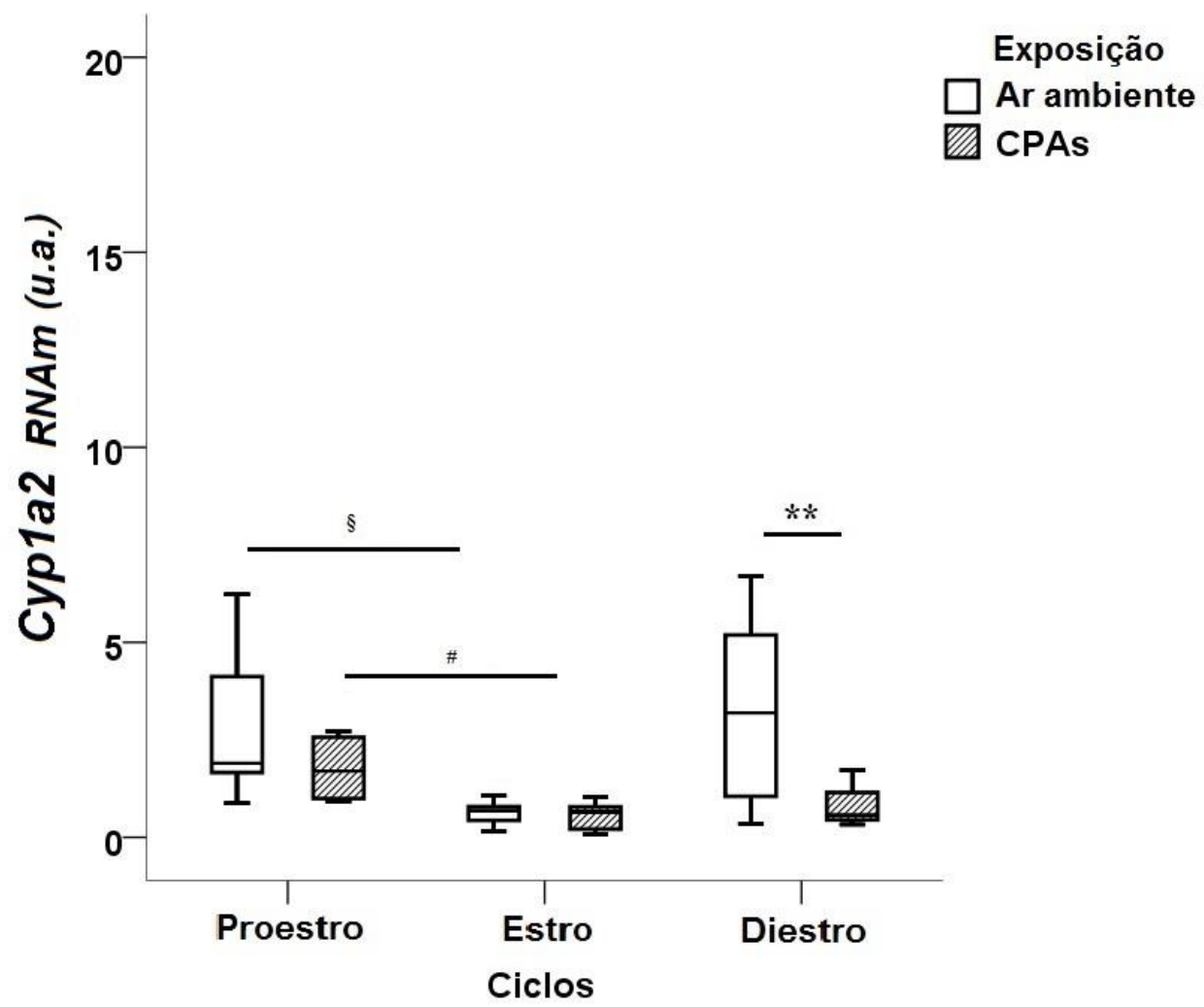

Figura 16. Representação gráfica da expressão de Cyp1a2 RNAm no epitélio nasal de camundongos fêmeas em 3 fases do ciclo estral (proestro, estro e diestro) após exposição subcrônica ao ar ambiente e $\mathrm{MP}_{2,5}$ concentrado a $600 \mu \mathrm{g} / \mathrm{m}^{3}$ no CPAs. A expressão gênica de Cyp1a2 no epitélio nasal de fêmeas na fase diestro foi menor no grupo exposto ao CPA quando comparado ao grupo exposto ao ar ambiente $\left({ }^{* *} p<0,05\right)$. A expressão gênica de fêmeas em proestro e estro é significantemente diferente quando comparada na exposição ao ar ambiente $\left({ }^{\S} \mathrm{p}=0,026\right)$ e ao CPA $\left({ }^{\#} \mathrm{p}=0,032\right)$. A expressão gênica foi normalizada pela expressão de $\beta$-actina e encontra-se representada como unidades arbitrárias (u.a.). Valores expressos em "boxplot" (a linha média define a mediana, as bordas acima e abaixo do retângulo representam os percentis $25 \%$ e $75 \%$ respectivamente, e as linhas terminais da barra de erro (abaixo e acima) representam os percentis $10 \%$ e $90 \%$, respectivamente). Camundongos fêmeas nas seguintes fases: proestro, expostos ao ar ambiente (PE/A) ( $n=7)$; proestro, expostos ao CPA (PE/MP) $(n=6)$; estro, expostos ao ar ambiente (E/A) (n=7); estro, expostos ao CPA (E/MP) $(n=6)$; diestro, expostos ao ar ambiente (D/A) $(n=6)$, e diestro, expostos ao CPA (D/MP) $(n=9)$. 
A expressão gênica de Cyp1b1 no epitélio nasal de fêmeas expostas ao CPA foi menor quando comparada à expressão das fêmeas expostas ao ar ambiente (Figura 17).

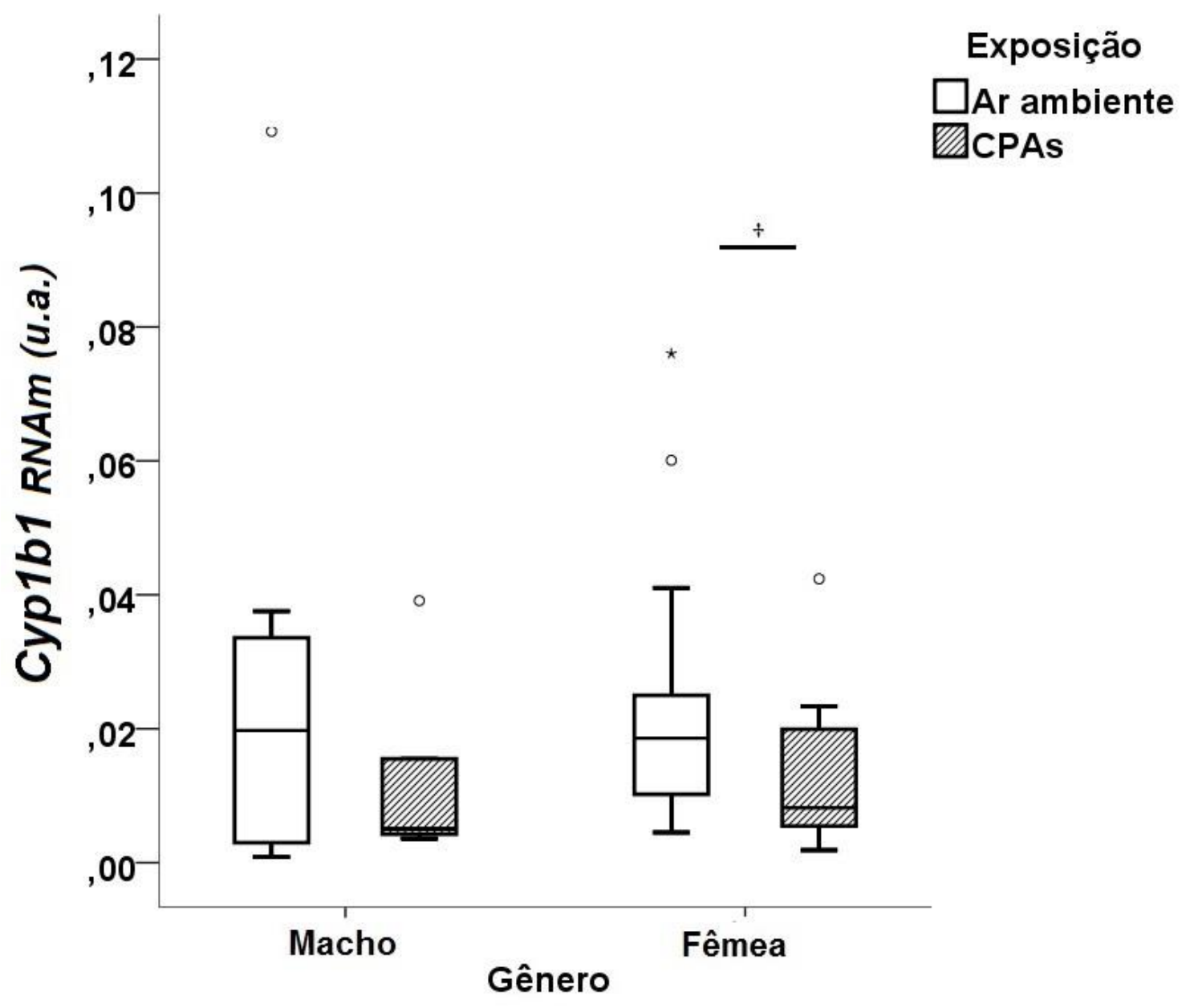

Figura 17. Representação gráfica da expressão de Cyp1b1 RNAm no epitélio nasal de camundongos machos e fêmeas após exposição subcrônica ao ar ambiente e $\mathrm{MP}_{2,5}$ concentrado a $600 \mu \mathrm{g} / \mathrm{m}^{3}$ no CPAs. A expressão gênica de Cyp1b1 no epitélio nasal de fêmeas expostas ao CPAs foi menor quando comparada ao grupo exposto ao ar ambiente $\left({ }^{\dagger} \mathrm{p}=0,01\right)$. A expressão gênica foi normalizada pela expressão de $\beta$-actina e encontra-se representada como unidades arbitrárias (u.a.). Valores expressos em "boxplot" (a linha média define a mediana, as bordas acima e abaixo do retângulo representam os percentis $25 \%$ e $75 \%$ respectivamente, e as linhas terminais da barra de erro (abaixo e acima) representam os percentis 10\% e 90\%, respectivamente). Camundongos machos expostos ao ar ambiente (M/A) ( $n=8)$, camundongos machos expostos ao CPA (M/MP) $(n=6)$, camundongos fêmeas expostos ao ar ambiente $(F / A)(n=20)$, camundongos fêmeas expostos ao CPA $(F / M P)(n=21)$. 
Observa-se, também, que a expressão gênica de Cyp1b1 no epitélio nasal de fêmeas em diestro expostas ao CPA diminuiu, em comparação ao grupo exposto ao ar ambiente. E, na fase estro, a expressão se mantém aumentada quando comparada aos grupos proestro e diestro expostos ao CPA (Figura 18).

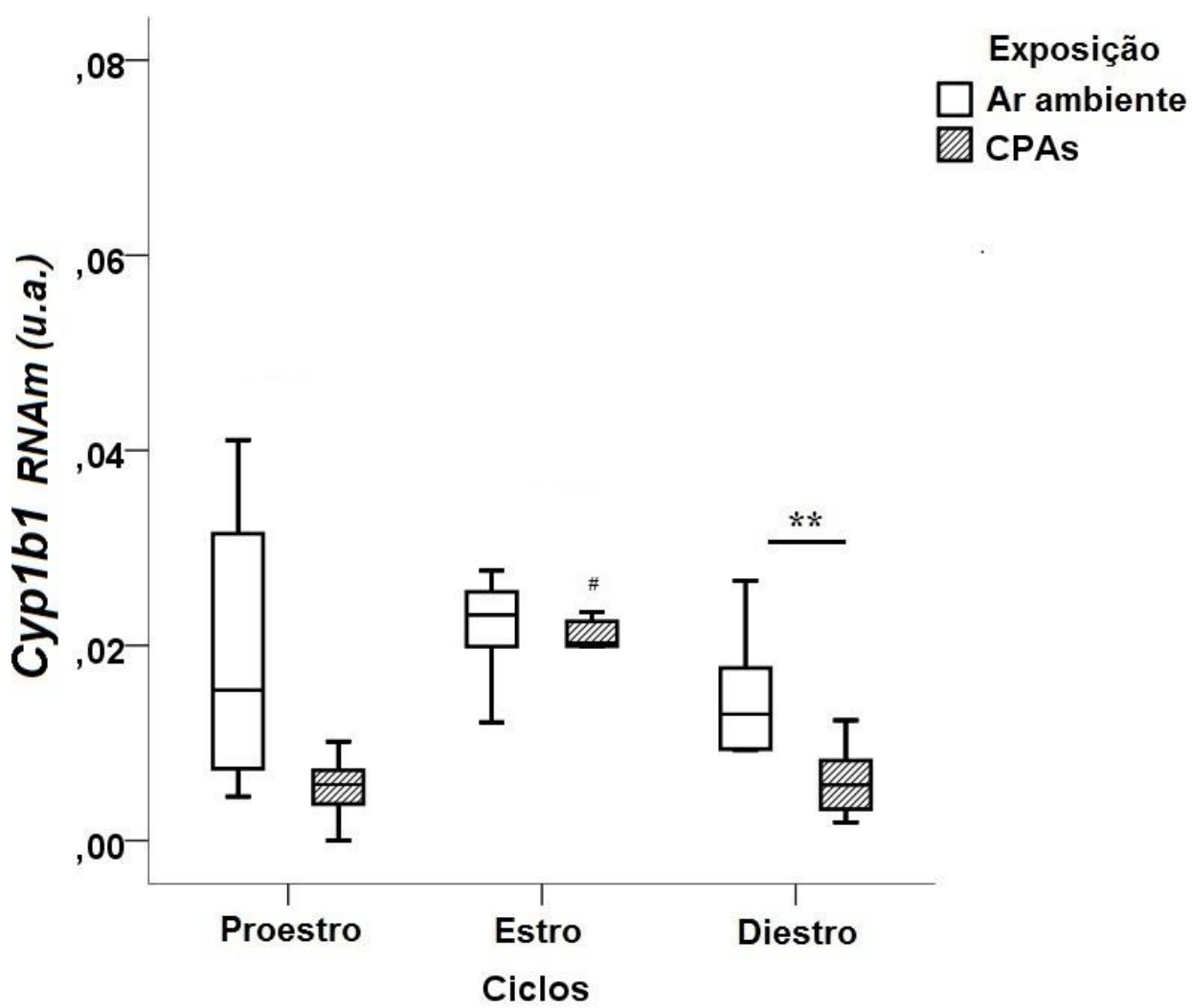

Figura 18. Representação gráfica da expressão de Cyp1b1 RNAm no epitélio nasal de camundongos fêmeas em 3 fases do ciclo estral (proestro, estro e diestro) após exposição subcrônica ao ar ambiente e $\mathrm{MP}_{2,5}$ concentrado a $600 \mu \mathrm{g} / \mathrm{m}^{3}$ no CPAs. A expressão gênica de Cyp1b1 no epitélio nasal de fêmeas em diestro expostas ao CPAs diminuiu quando comparada ao grupo exposto ao ar ambiente $\left({ }^{* *} p=0,036\right)$. E na fase estro, a expressão se mantém aumentada quando comparada a dos grupos proestro e diestro expostos ao CPA ( $\left.{ }^{\#}=0,01\right)$. A expressão gênica foi normalizada pela expressão de $\beta$-actina e encontra-se representada como unidades arbitrárias (u.a.). Valores expressos em "boxplot" (a linha média define a mediana, as bordas acima e abaixo do retângulo representam os percentis $25 \%$ e $75 \%$ respectivamente, e as linhas terminais da barra de erro (abaixo e acima) representam os percentis $10 \%$ e $90 \%$, respectivamente). Camundongos fêmeas nas seguintes fases: proestro, que foram expostos ao ar ambiente (PE/A) ( $n=7)$; proestro, que foram expostos ao CPA (PE/MP) ( $n=6)$; estro, expostos ao ar ambiente $(E / A)(n=7)$; estro, expostos ao CPA (E/MP) ( $n=6)$; diestro, expostos ao ar ambiente (D/A) $(n=6)$, e diestro, expostos ao CPA (D/MP) $(n=9)$. 
Em relação à expressão gênica de $\operatorname{Er\beta }-1$ no epitélio nasal de camundongos machos e fêmeas e entre as 3 fases do ciclo estral (proestro, estro e diestro) de camundongos fêmeas, após exposição ao ar ambiente e ao CPA não foi observada diferença estatística significativa entre os grupos (Figuras 19 e 20).

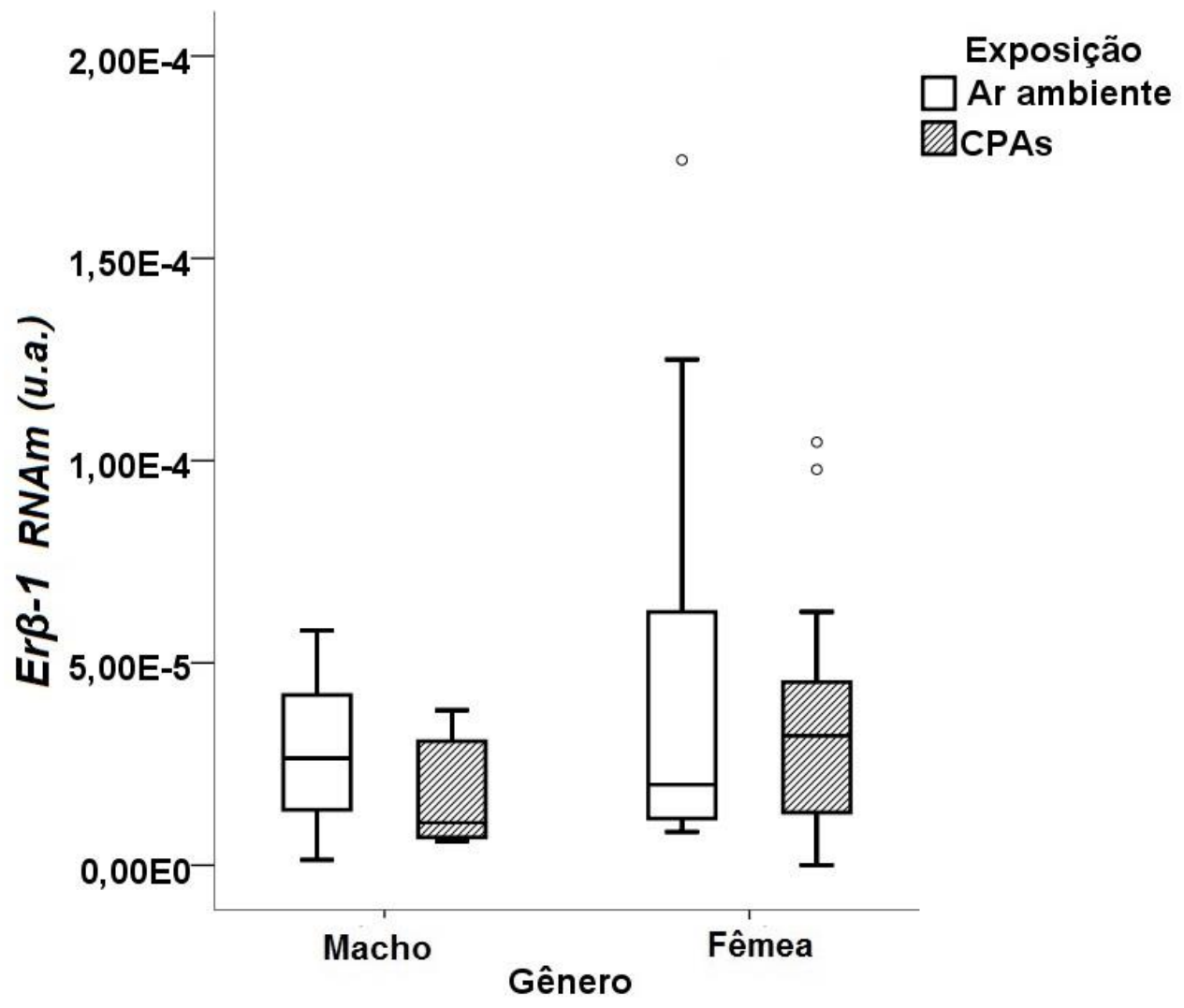

Figura 19. Representação gráfica da expressão de $\operatorname{Er} \beta-1$ RNAm no epitélio nasal de camundongos machos e fêmeas após exposição subcrônica ao ar ambiente e $\mathrm{MP}_{2,5}$ concentrado a $600 \mu \mathrm{g} / \mathrm{m}^{3}$ no CPAs. Não houve diferença estatística entre os grupos na expressão gênica de $\operatorname{Er} \beta-1$ no epitélio nasal. A expressão gênica foi normalizada pela expressão de $\beta$-actina e encontra-se representada como unidades arbitrárias (u.a.). Valores expressos em "boxplot" (a linha média define a mediana, as bordas acima e abaixo do retângulo representam os percentis $25 \%$ e $75 \%$ respectivamente, e as linhas terminais da barra de erro (abaixo e acima) representam os percentis $10 \%$ e $90 \%$, respectivamente). Camundongos machos expostos ao ar ambiente $(M / A)(n=7)$, camundongos machos expostos ao CPA (M/MP) $(n=6)$, camundongos fêmeas expostos ao ar ambiente $(F / A)(n=18)$, camundongos fêmeas expostos ao CPA $(F / M P)(n=19)$. 


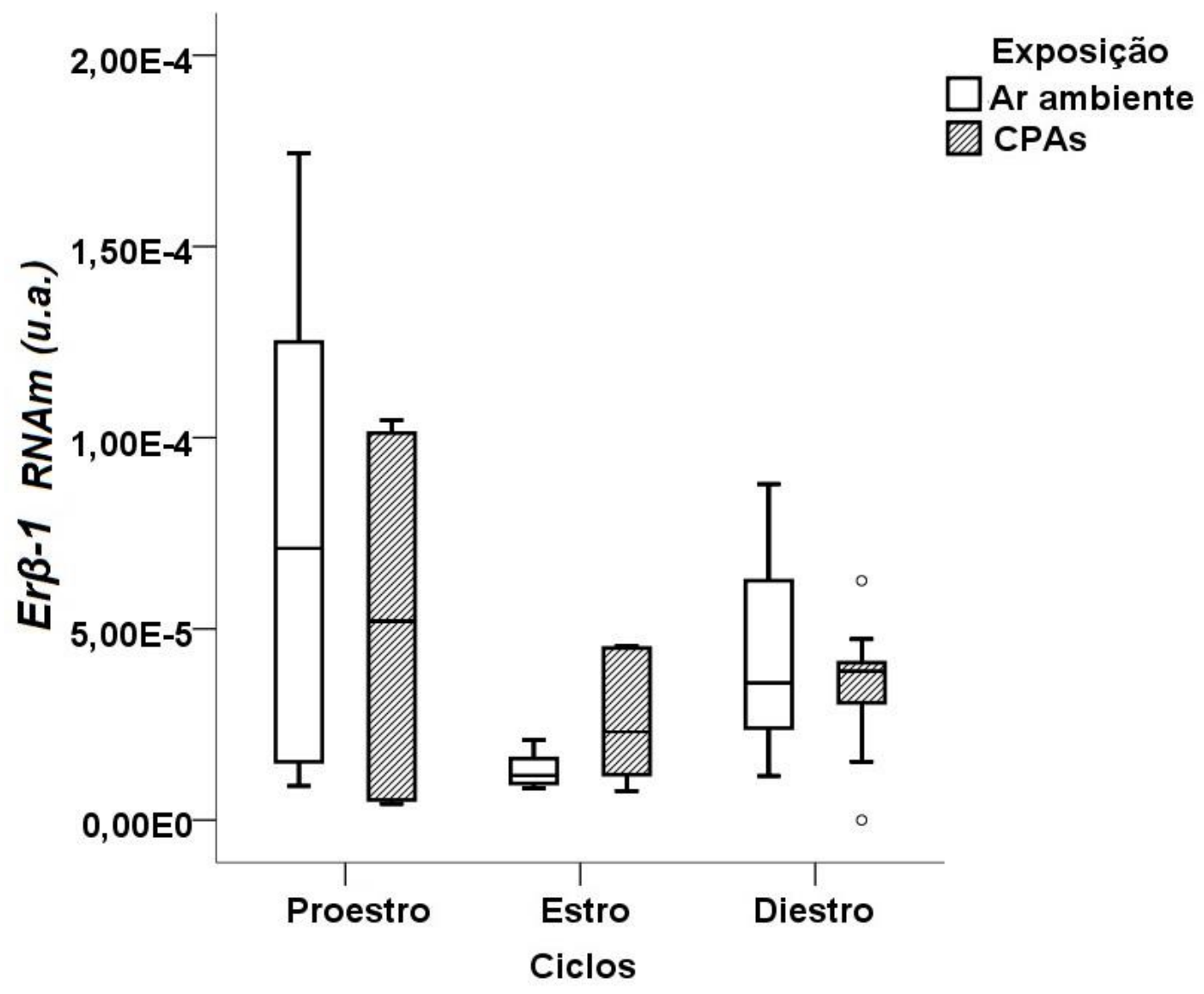

Figura 20. Representação gráfica da expressão de $\operatorname{Er} \beta-1$ RNAm no epitélio nasal de camundongos fêmeas em 3 fases do ciclo estral (proestro, estro e diestro) após exposição subcrônica ao ar ambiente e $\mathrm{MP}_{2,5}$ concentrado a $600 \mu \mathrm{g} / \mathrm{m}^{3}$ no CPAs. Não houve diferença estatística entre os grupos na expressão gênica de Erß-1 no epitélio nasal. A expressão gênica foi normalizada pela expressão de $\beta$-actina e encontra-se representada como unidades arbitrárias (u.a.). Valores expressos em "boxplot" (a linha média define a mediana, as bordas acima e abaixo do retângulo representam os percentis $25 \%$ e $75 \%$ respectivamente, e as linhas terminais da barra de erro (abaixo e acima) representam os percentis 10\% e 90\%, respectivamente). Camundongos fêmeas nas seguintes fases: proestro, expostos ao ar ambiente (PE/A) ( $n=5)$; proestro, expostos ao CPA (PE/MP) ( $n=4)$; estro, expostas ao ar ambiente (E/A) (n=7); estro, expostos ao CPA (E/MP) ( $n=6)$; diestro expostos ao ar ambiente (D/A) $(n=6)$, e diestro, expostos ao CPA (D/MP) $(n=9)$. 
A expressão gênica de Erß-2 no epitélio nasal de fêmeas expostas ao CPAs diminuiu quando comparada ao grupo exposto ao ar ambiente e aos machos expostos ao CPA (Figura 21).

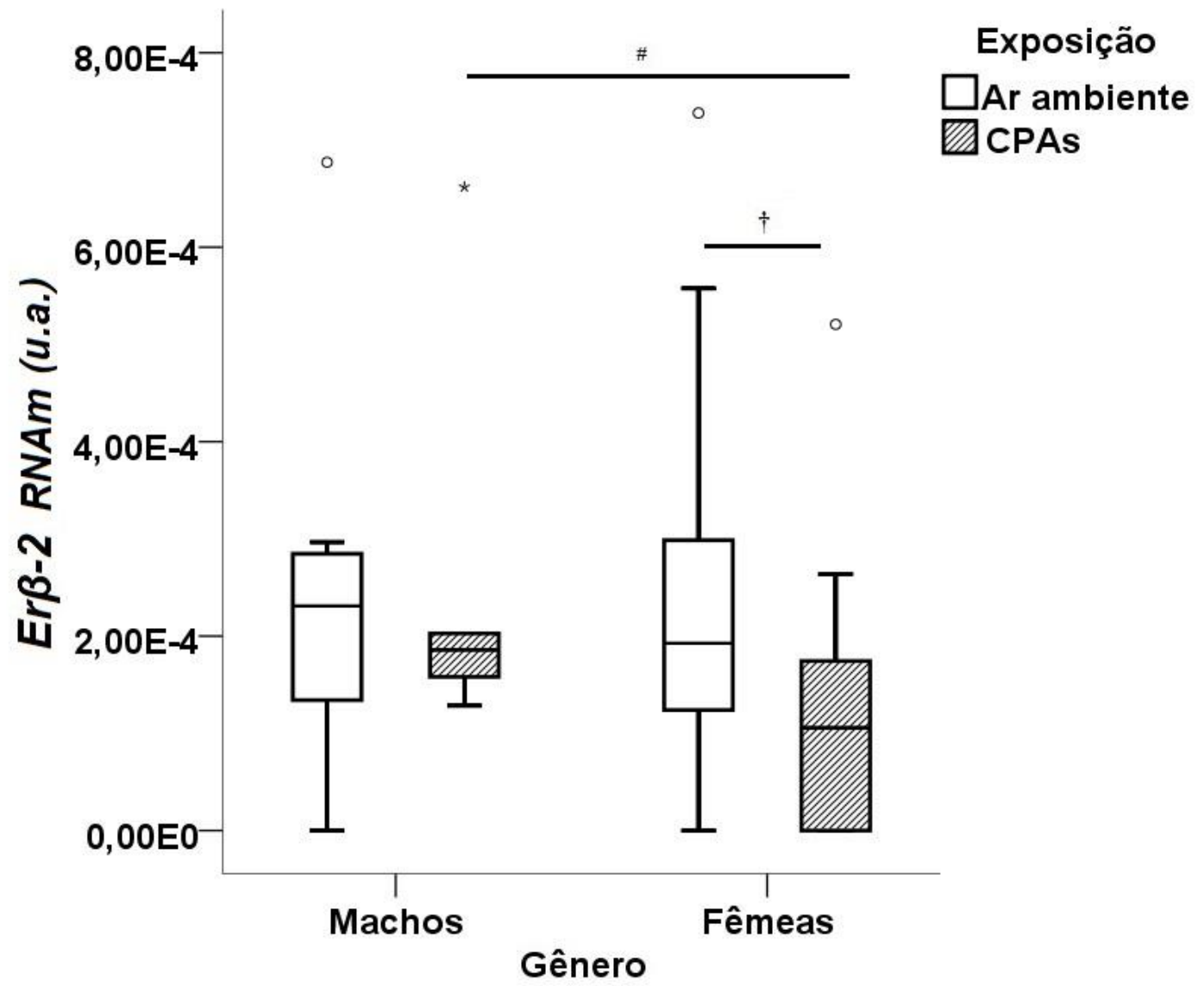

Figura 21. Representação gráfica da expressão de Erß-2 RNAm no epitélio nasal de camundongos machos e fêmeas após exposição subcrônica ao ar ambiente e $\mathrm{MP}_{2,5}$ concentrado a $600 \mu \mathrm{g} / \mathrm{m}^{3}$ no CPAs. A expressão gênica de Erß-2 no epitélio nasal de fêmeas expostas ao CPAs diminuiu quando comparada a do grupo exposto ao ar ambiente $\left({ }^{\dagger} p=0,007\right)$ e a dos machos expostos ao CPAs $(\# p=0,036)$. A expressão gênica foi normalizada pela expressão de $\beta$-actina e encontra-se representada como unidades arbitrárias (u.a.). Valores expressos em "boxplot" (a linha média define a mediana, as bordas acima e abaixo do retângulo representam os percentis $25 \%$ e $75 \%$ respectivamente, e as linhas terminais da barra de erro (abaixo e acima) representam os percentis $10 \%$ e $90 \%$, respectivamente). Camundongos machos expostos ao ar ambiente $(M / A)(n=8)$, camundongos machos expostos ao CPA (M/MP) ( $n=6)$, camundongos fêmeas expostos ao ar ambiente ( $F / A)$ $(n=19)$, camundongos fêmeas expostos ao CPA (F/MP) $(n=19)$. 
$\mathrm{Na}$ fase diestro de fêmeas expostas ao CPA, a expressão gênica de Erß-2 no epitélio nasal diminuiu quando comparada ao grupo exposto ao ar ambiente (Figura 22).

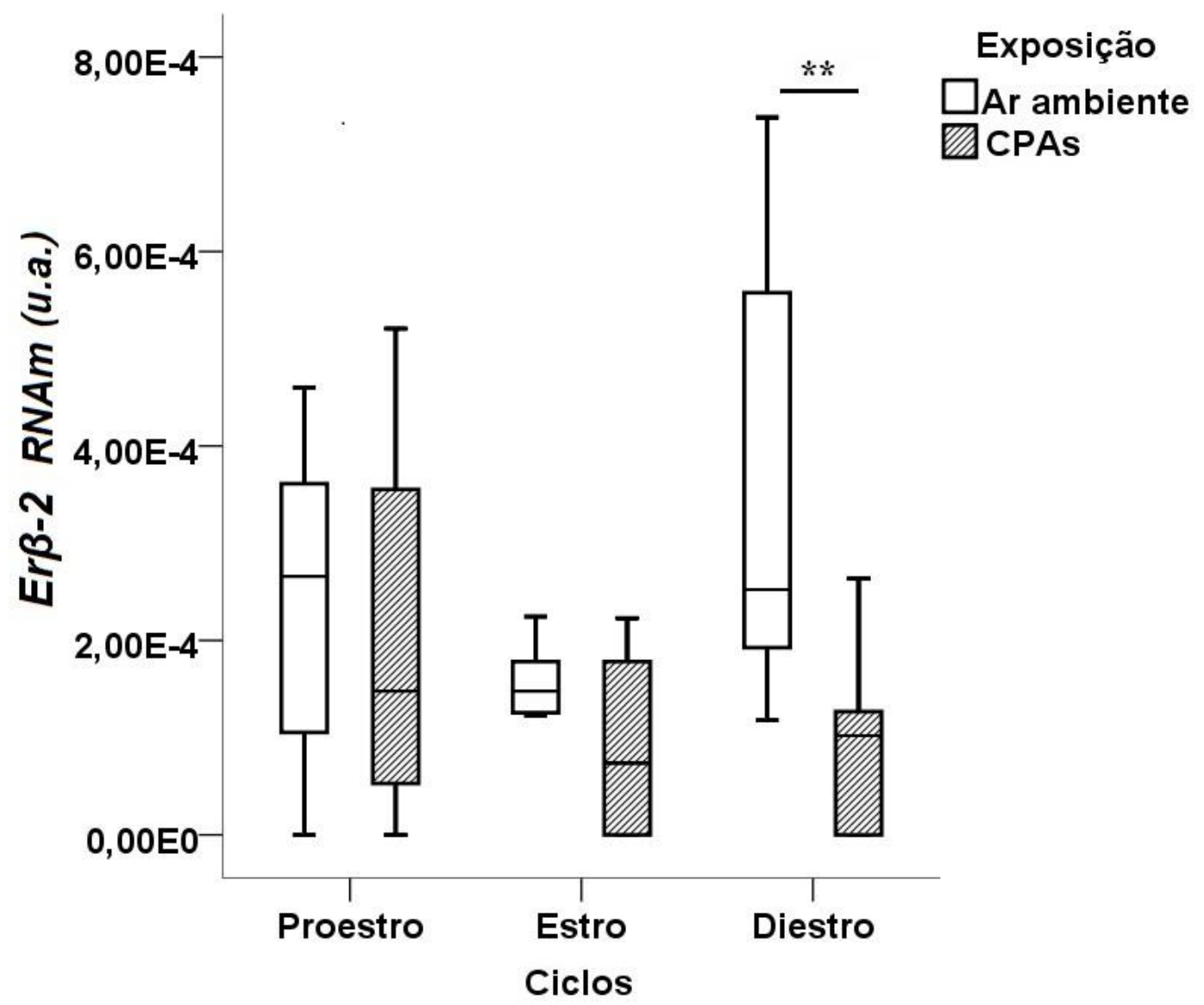

Figura 22. Representação gráfica da expressão de Erß-2 RNAm no epitélio nasal de camundongos fêmeas em 3 fases do ciclo estral (proestro, estro e diestro) após exposição subcrônica ao ar ambiente e $\mathrm{MP}_{2,5}$ concentrado a $600 \mu \mathrm{g} / \mathrm{m}^{3}$ no CPA. A expressão gênica de $\operatorname{Er} \beta-2$ no epitélio nasal de fêmeas em diestro foi menor no grupo exposto ao CPAs quando comparado ao grupo exposto ao ar ambiente $\left({ }^{* *} \mathrm{p}=0,008\right)$. A expressão gênica foi normalizada pela expressão de $\beta$-actina e encontra-se representada como unidades arbitrárias (u.a.). Valores expressos em "boxplot" (a linha média define a mediana, as bordas acima e abaixo do retângulo representam os percentis $25 \%$ e $75 \%$ respectivamente, e as linhas terminais da barra de erro (abaixo e acima) representam os percentis $10 \%$ e $90 \%$, respectivamente). Fêmeas nas seguintes fases: proestro, expostos ao ar ambiente (PE/A) ( $n=7)$; proestro, expostos ao CPA (PE/MP) ( $n=4)$; estro, expostos ao ar ambiente $(E / A)(n=6)$; estro, expostos ao CPA (E/MP) $(n=6)$; diestro, expostos ao ar ambiente $(D / A)$ $(n=6)$, e diestro, expostos ao CPAs (D/MP) $(n=9)$. 
Em relação à expressão gênica de $A h r$ no epitélio nasal de camundongos machos e fêmeas e entre as 3 fases do ciclo estral (proestro, estro e diestro) de camundongos fêmeas, após exposição ao ar ambiente e ao CPA não foi observado diferença estatística significativa entre os grupos (Figuras 23 e 24).

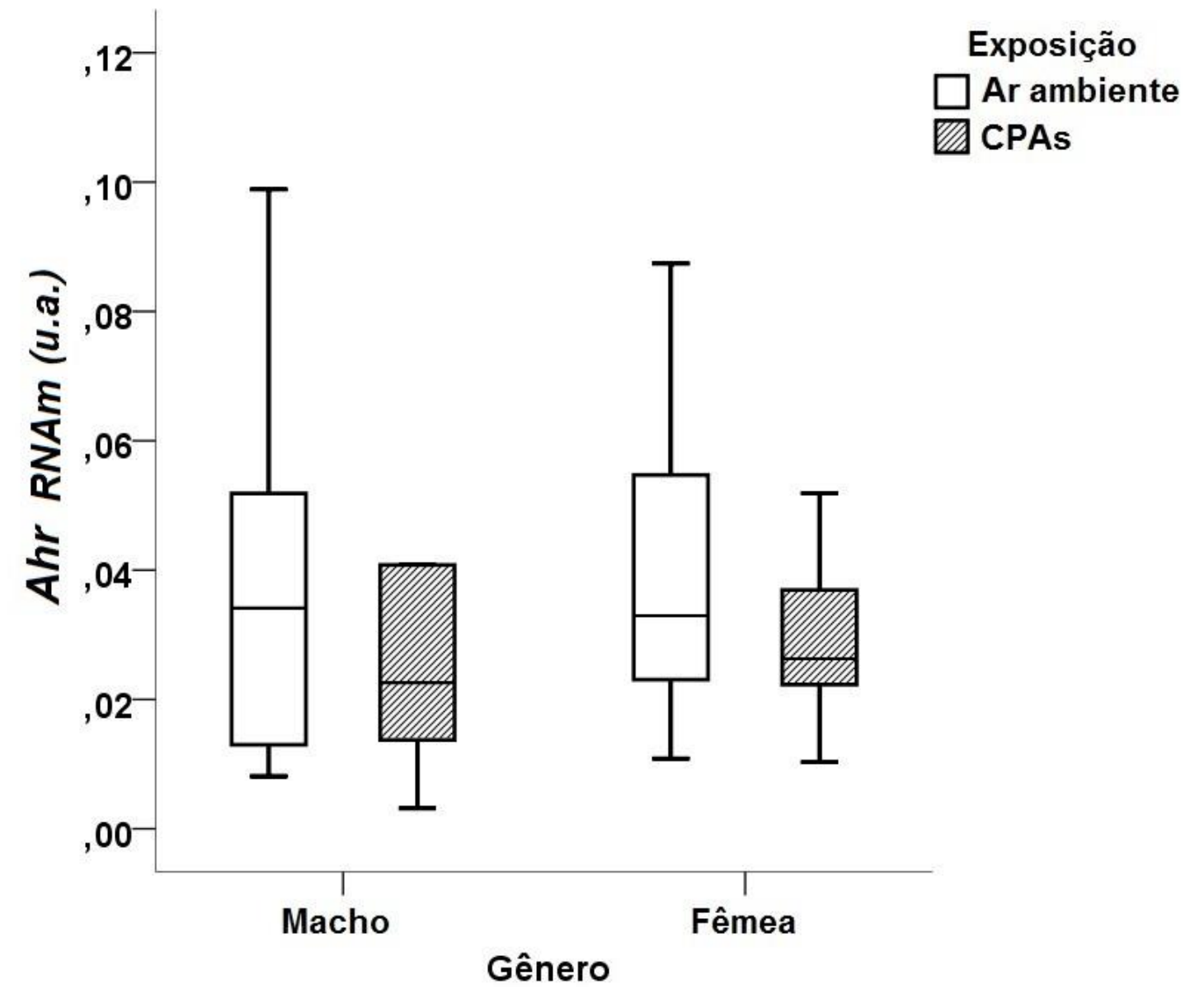

Figura 23. Representação gráfica da expressão de $A h R$ RNAm no epitélio nasal de camundongos machos e fêmeas após exposição subcrônica ao ar ambiente e $\mathrm{MP}_{2,5}$ concentrado a $\sim 600 \mu \mathrm{g} / \mathrm{m}^{3}$ no CPA. Não houve diferença estatística entre os grupos na expressão gênica de $A h R$ no epitélio nasal. A expressão gênica foi normalizada pela expressão de $\beta$-actina e encontra-se representada como unidades arbitrárias (u.a.). Valores expressos em "boxplot" (a linha média define a mediana, as bordas acima e abaixo do retângulo representam os percentis $25 \%$ e $75 \%$ respectivamente, e as linhas terminais da barra de erro (abaixo e acima) representam os percentis $10 \%$ e $90 \%$, respectivamente). Camundongos machos expostos ao ar ambiente $(M / A)(n=8)$, camundongos machos expostos ao CPA (M/MP) $(n=6)$, camundongos fêmeas expostos ao ar ambiente ( $F / A)(n=20)$, camundongos fêmeas expostos ao CPAs (F/MP) $(n=21)$. 


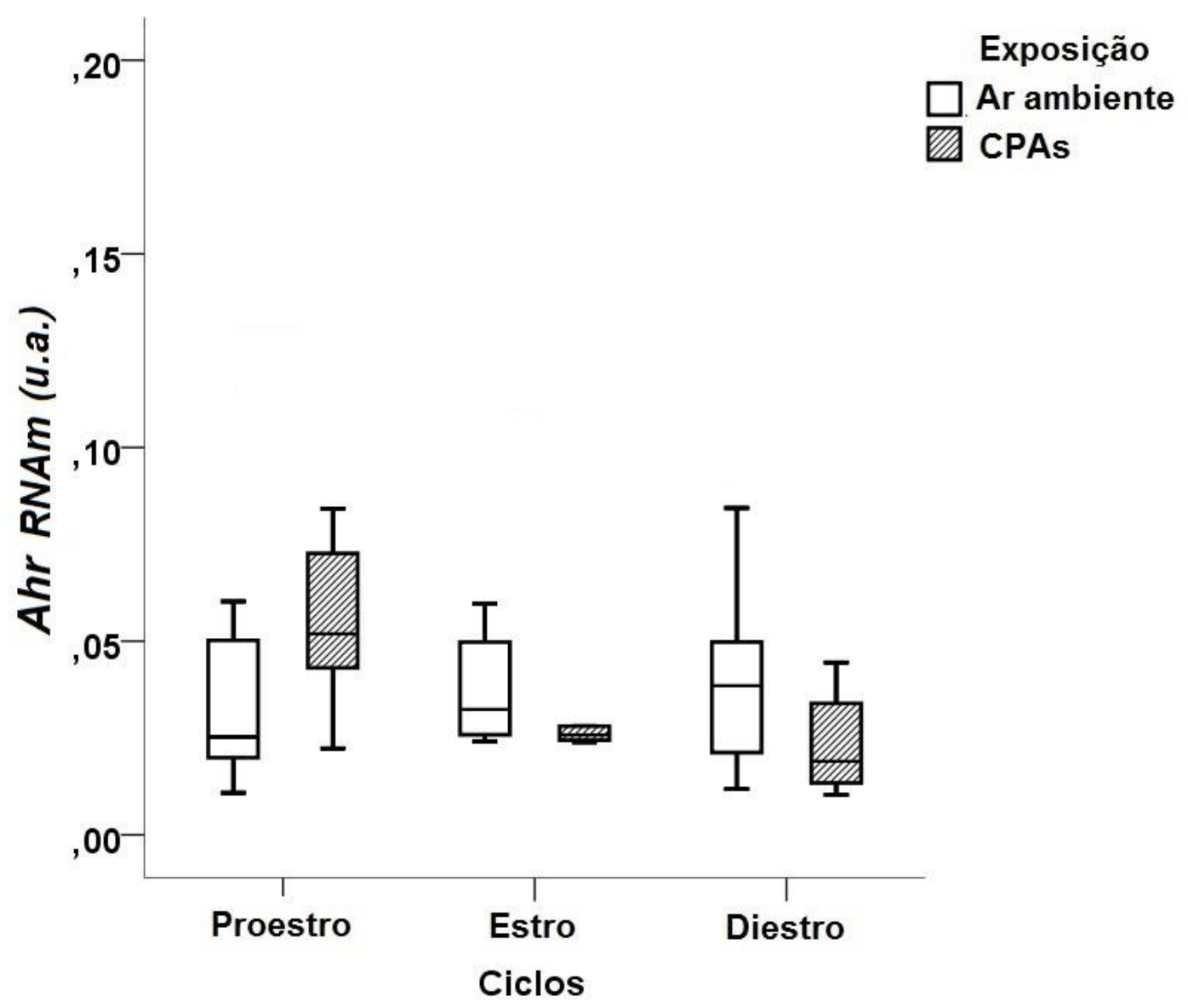

Figura 24. Representação gráfica da expressão de $A h R$ RNAm no epitélio nasal de camundongos fêmeas em 3 fases do ciclo estral (proestro, estro e diestro) após exposição subcrônica ao ar ambiente e $\mathrm{MP}_{2,5}$ concentrado a $600 \mu \mathrm{g} / \mathrm{m}^{3}$ no CPA. Não houve diferença estatística entre os grupos na expressão gênica de $A h R$ no epitélio nasal. A expressão gênica foi normalizada pela expressão de $\beta$-actina e encontra-se representada como unidades arbitrárias (u.a.). Valores expressos em "boxplot" (a linha média define a mediana, as bordas acima e abaixo do retângulo representam os percentis $25 \%$ e $75 \%$ respectivamente, e as linhas terminais da barra de erro (abaixo e acima) representam os percentis $10 \%$ e $90 \%$, respectivamente). Camundongos fêmeas nas seguintes fases: proestro, expostos ao ar ambiente $(P E / A)(n=7)$; proestro, expostos ao CPAs (PE/MP) $(n=6)$; estro, expostos ao ar ambiente (E/A) $(n=7)$; estro, expostos ao CPA (E/MP) ( $n=6)$; diestro, expostos ao ar ambiente $(D / A)(n=6)$, e diestro, expostos ao CPAs (D/MP) $(n=9)$. 


\subsection{Análise imuno-histoquímica}

A expressão de receptores no epitélio nasal foi avaliada por meio da quantificação da área imunomarcada para AhR e ERß em relação à área total analisada no epitélio nos grupos machos e fêmeas, após exposição ao ar ambiente e $\mathrm{MP}_{2,5}$ concentrado a $600 \mu \mathrm{g} / \mathrm{m}^{3}$ no CPA.

Fêmeas expostas ao CPA apresentam expressão aumentada de Erß no epitélio nasal quando comparadas aos machos expostos ao CPA (Figura 25).

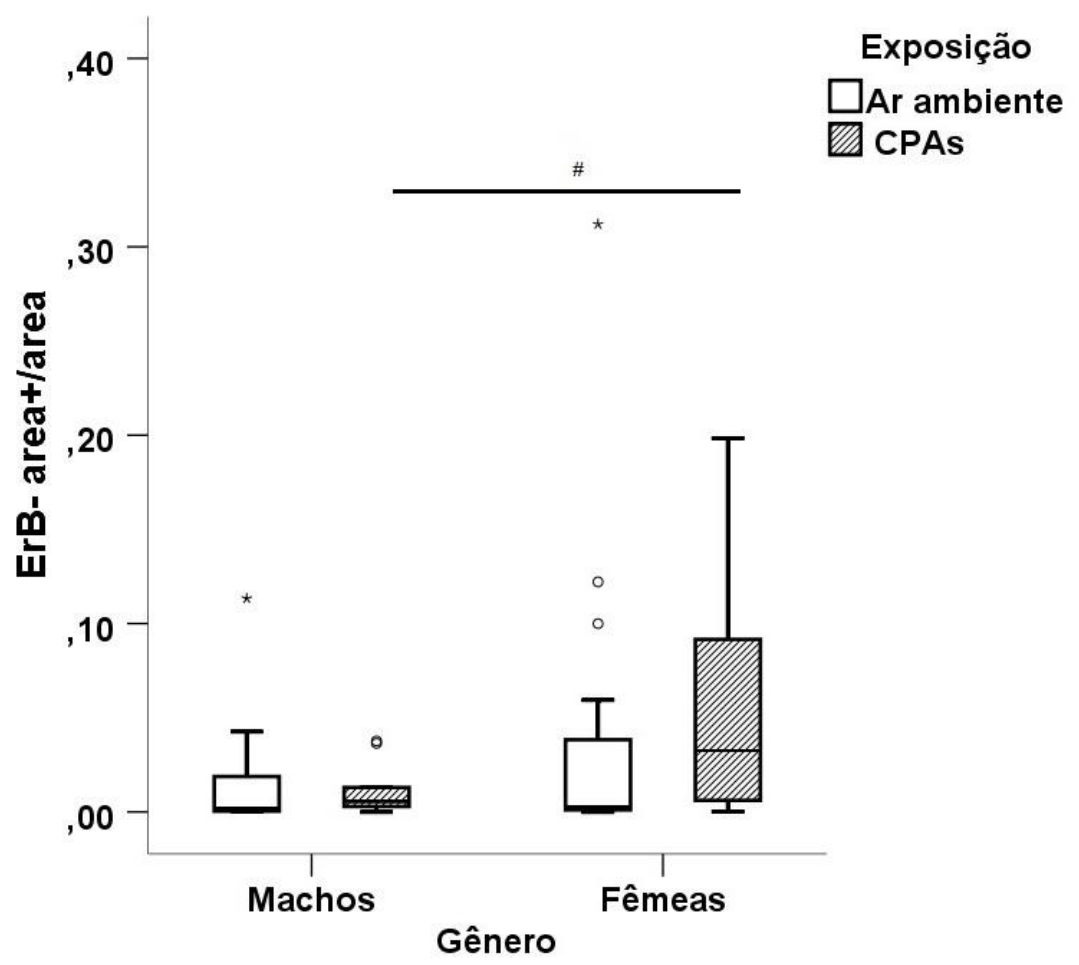

Figura 25. Representação gráfica da expressão de $\operatorname{Er} \beta$ (proteína) no epitélio nasal de camundongos machos e fêmeas após exposição subcrônica ao ar ambiente e $\mathrm{MP}_{2,5}$ concentrado a $\sim 600 \mu \mathrm{g} / \mathrm{m}^{3}$ no CPA. Fêmeas expostas ao CPA apresentam expressão aumentada de $\operatorname{Er} \beta$ no epitélio nasal quando comparadas aos machos expostos ao CPA ( $\left.{ }^{*} \mathrm{p}=0,034\right)$. Valores expressos em "boxplot" (a linha média define a mediana, as bordas acima e abaixo do retângulo representam os percentis $25 \%$ e $75 \%$ respectivamente, e as linhas terminais da barra de erro (abaixo e acima) representam os percentis $10 \%$ e $90 \%$, respectivamente). Camundongos machos expostos ao ar ambiente (M/A) $(n=9)$, camundongos machos expostos ao CPA (M/MP) $(n=9)$, camundongos fêmeas expostos ao ar ambiente $(F / A)(n=19)$, camundongos fêmeas expostos ao CPA (F/MP) $(\mathrm{n}=23)$. 
Nas 3 fases do ciclo estral das fêmeas, observa-se que a expressão de Erß no epitélio nasal de fêmeas em estro aumentou quando comparada ao grupo exposto ao ar ambiente (Figura 26).

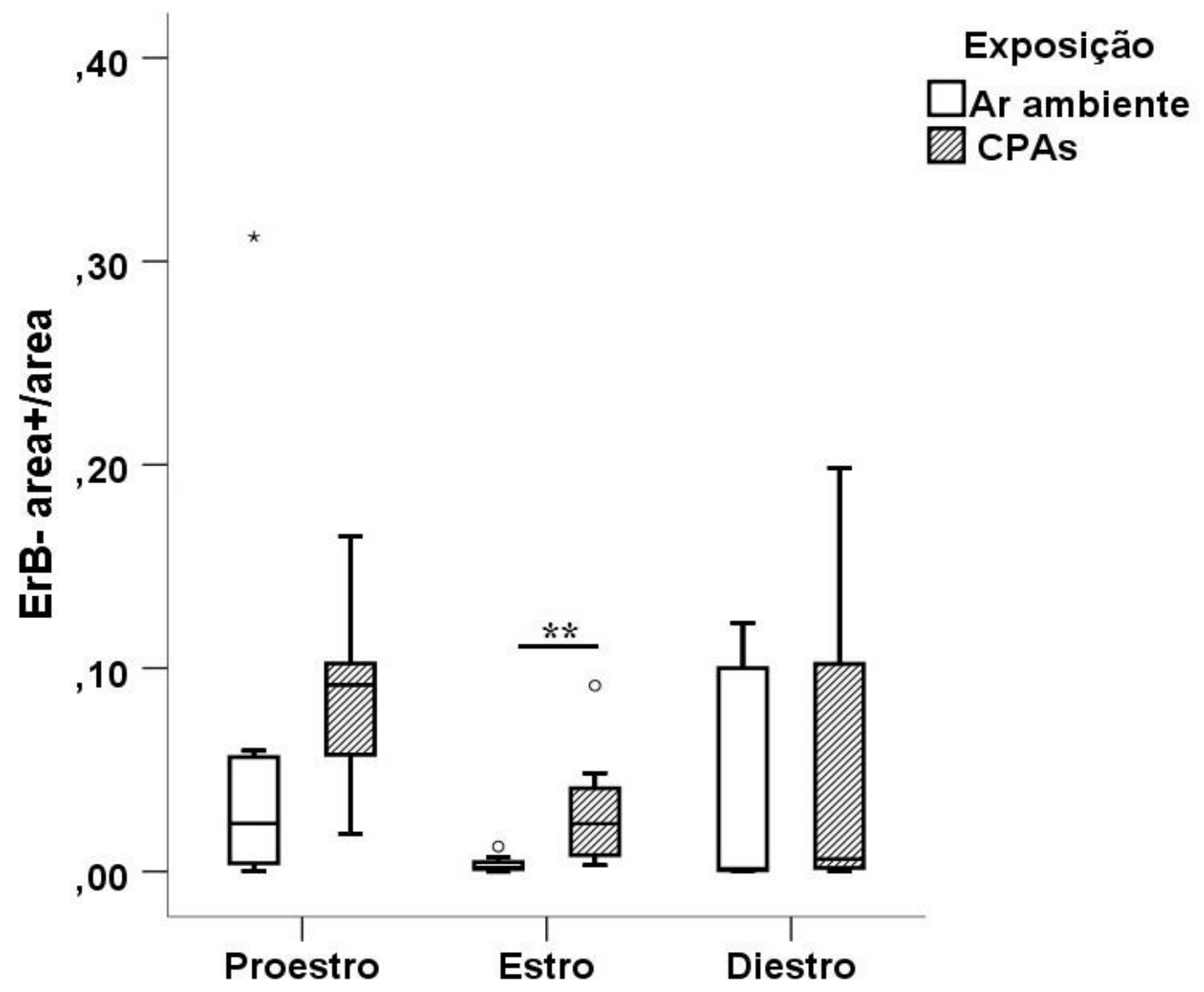

Figura 26. Representação gráfica da expressão protéica de $\operatorname{Er} \beta$ no epitélio nasal de camundongos fêmeas em 3 fases do ciclo estral (proestro, estro e diestro) após exposição subcrônica ao ar ambiente e $\mathrm{MP}_{2,5}$ concentrado a $600 \mu \mathrm{g} / \mathrm{m}^{3}$ no CPA. A expressão de $\operatorname{Er} \beta$ no epitélio nasal de fêmeas em estro aumentou quando comparada ao grupo exposto ao ar ambiente $\left({ }^{* *} p=0,005\right)$. Valores expressos em "boxplot" (a linha média define a mediana, as bordas acima e abaixo do retângulo representam os percentis $25 \%$ e $75 \%$ respectivamente, e as linhas terminais da barra de erro (abaixo e acima) representam os percentis $10 \%$ e $90 \%$, respectivamente). Camundongos fêmeas nas seguintes fases: proestro, que foram expostos ao ar ambiente (PE/A) ( $n=7)$; proestro, expostos ao CPA (PE/MP) $(n=5)$; estro, expostas ao ar ambiente (E/A) $(n=7)$; estro, expostos ao CPA (E/MP) $(n=9)$; diestro, expostos ao ar ambiente $(D / A)(n=5)$, e diestro, expostos ao CPA (D/MP) $(n=9)$. 
Não houve diferença estatística significativa para a expressão proteica de AhR no epitélio nasal de camundongos machos e fêmeas, e entre os ciclos estrais, após exposição ao ar ambiente e $\mathrm{MP}_{2,5}$ concentrado a $600 \mu \mathrm{g} / \mathrm{m}^{3}$ no CPA (Figuras 27 e 28).

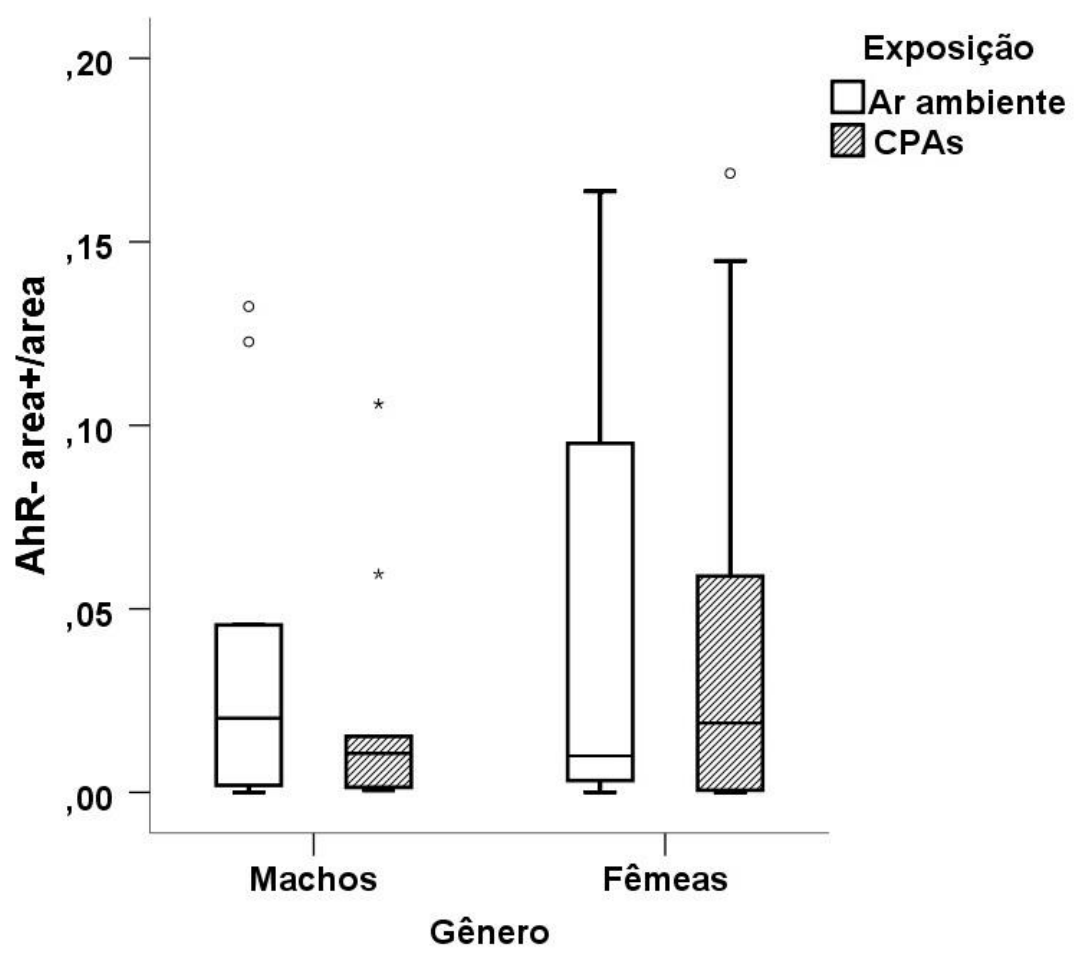

Figura 27. Representação gráfica da expressão proteica de AhR no epitélio nasal de camundongos machos e fêmeas após exposição subcrônica ao ar ambiente e $\mathrm{MP}_{2,5}$ concentrado a $600 \mu \mathrm{g} / \mathrm{m}^{3}$ no CPAs. Não houve diferença estatística entre os grupos na expressão de AhR no epitélio nasal. Valores expressos em "boxplot" (a linha média define a mediana, as bordas acima e abaixo do retângulo representam os percentis $25 \%$ e $75 \%$ respectivamente, e as linhas terminais da barra de erro (abaixo e acima) representam os percentis $10 \%$ e $90 \%$, respectivamente). Camundongos machos expostos ao ar ambiente $(\mathrm{M} / \mathrm{A})(\mathrm{n}=9)$, camundongos machos expostos ao CPA (M/MP) (n=9), camundongos fêmeas expostos ao ar ambiente $(F / A)(n=19)$, camundongos fêmeas expostos ao CPAs (F/MP) ( $n=23)$. 


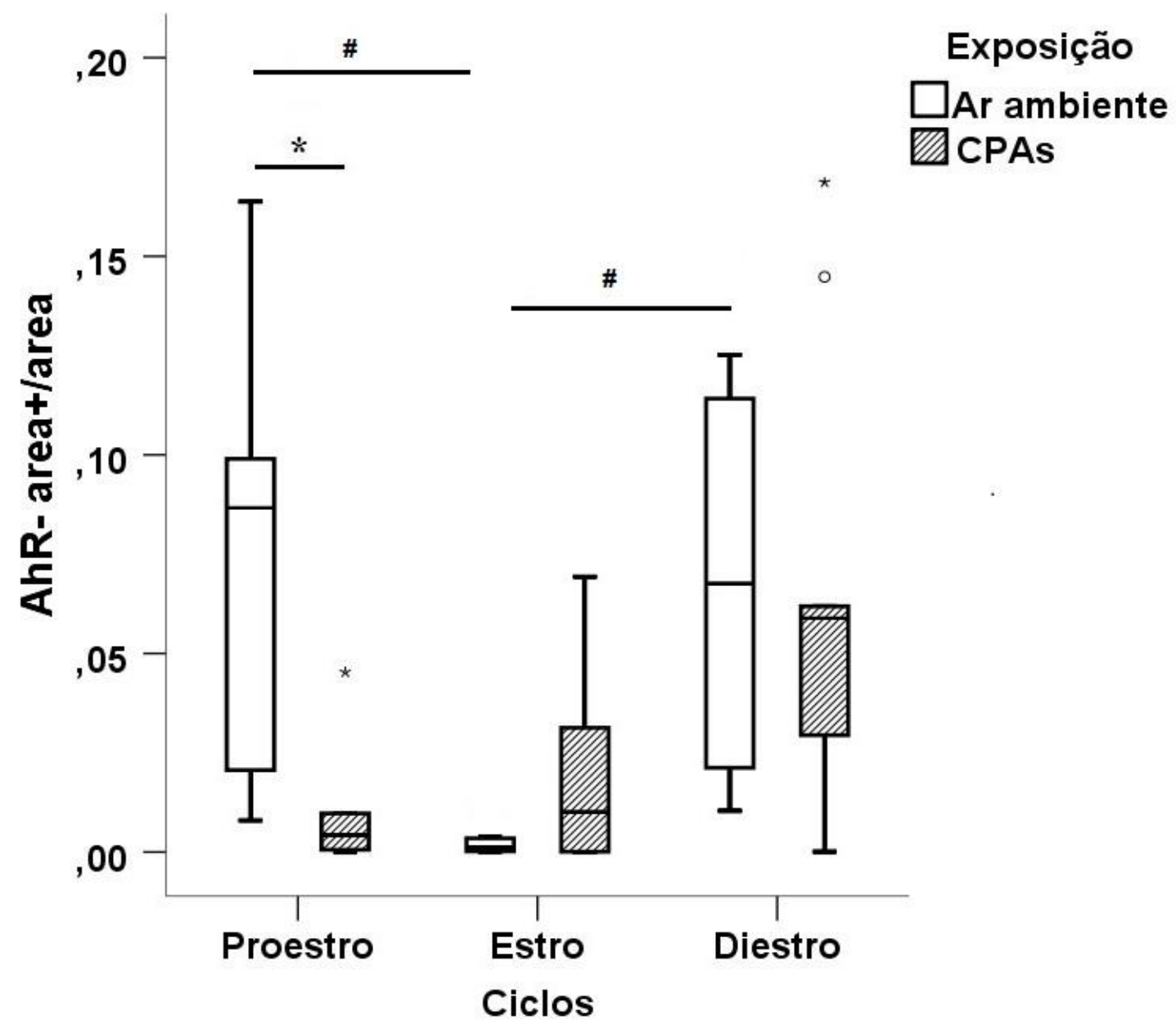

Figura 28. Representação gráfica da expressão proteica de $A h R$ no epitélio nasal de camundongos fêmeas em 3 fases do ciclo estral (proestro, estro e diestro) após exposição subcrônica ao ar ambiente e $\mathrm{MP}_{2,5}$ concentrado a $600 \mu \mathrm{g} / \mathrm{m}^{3}$ no CPA. Não houve diferença estatística entre os grupos na expressão de AhR no epitélio nasal. Valores expressos em "boxplot" (a linha média define a mediana, as bordas acima e abaixo do retângulo representam os percentis $25 \%$ e $75 \%$ respectivamente, e as linhas terminais da barra de erro (abaixo e acima) representam os percentis $10 \%$ e $90 \%$, respectivamente). Fêmeas nas seguintes fases: proestro, que foram expostas ao ar ambiente (PE/A) $(n=7)$; proestro, expostas ao CPAs (PE/MP) $(n=5)$; estro, expostas ao ar ambiente $(E / A)(n=7)$; estro, expostas ao CPA (E/MP) $(n=9)$; diestro, expostas ao ar ambiente (D/A) $(n=5)$, e diestro, expostas ao CPA (D/MP) $(n=9)$. 


\subsection{Análise do muco ácido e muco neutro}

Na Figura 29 observam-se as marcações com ácido periódico de Schiff (neutro) e azul de alciano (ácido) (PAS/AB) nas secções histológicas do epitélio nasal de camundongos machos e fêmeas (proestro, estro, diestro) que foram expostos ao material particulado concentrado e ao ar ambiente. Essa figura mostra o epitélio respiratório nasal, evidenciando a região de muco neutro, muco ácido e células ciliadas. 

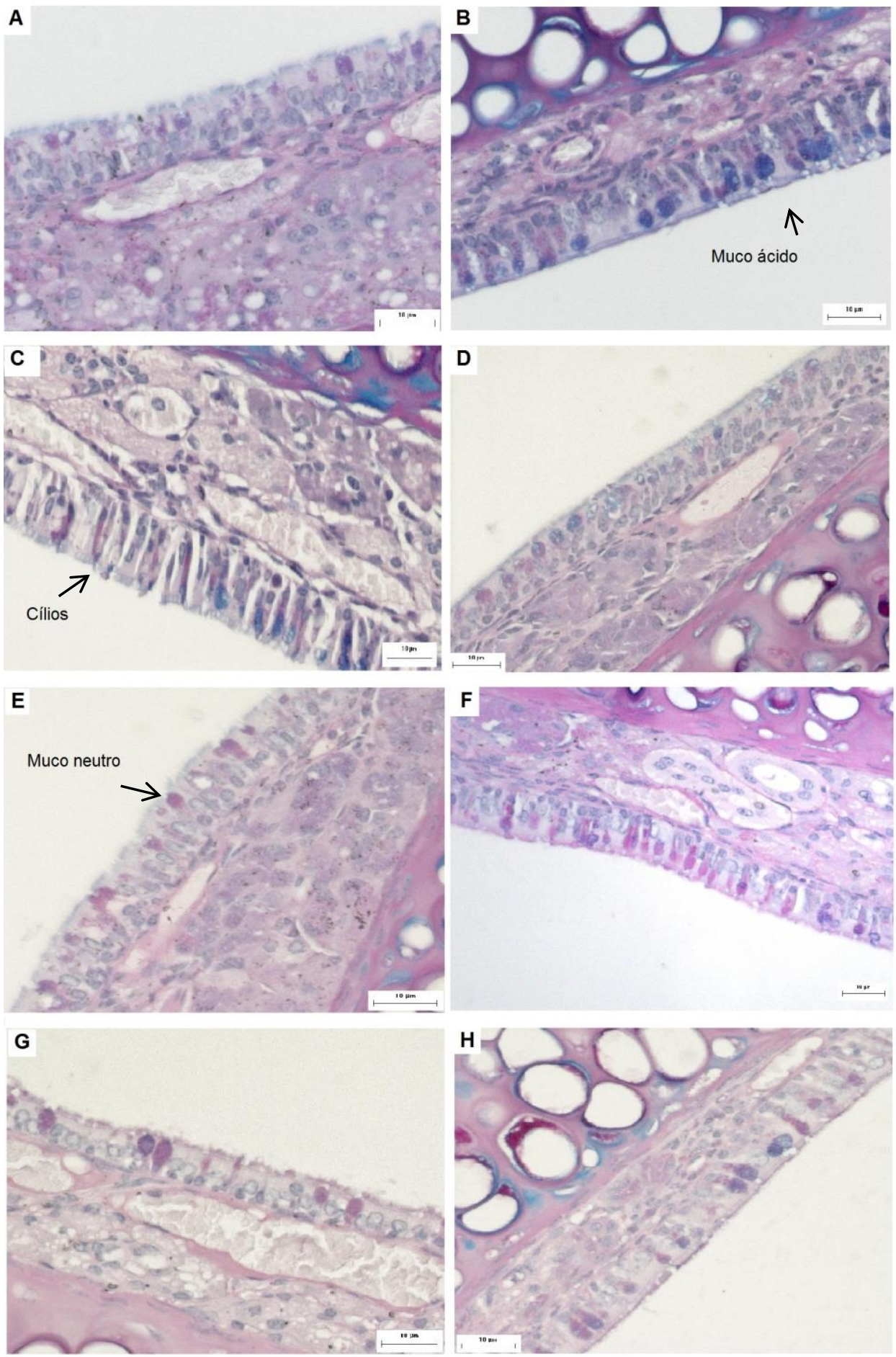

Figura 29. Fotomicrografias do epitélio nasal de camundongos expostos ao ar ambiente (A: machos, C: fêmeas em proestro, E: fêmeas em estro, G: fêmeas em diestro) e ao material particulado concentrado (B: machos, D: fêmeas em proestro, F: fêmeas em estro, $\mathbf{H}$ : fêmeas em diestro) e corados com ácido periódico DCE Schiff (neutro) e azul de alcian (ácido) - PAS/AB, aumento de 1380x. 
A quantidade expressa de muco neutro no epitélio nasal foi maior nos machos do que nas fêmeas, ambos expostos em ar ambiente e CPA (Figura 30).

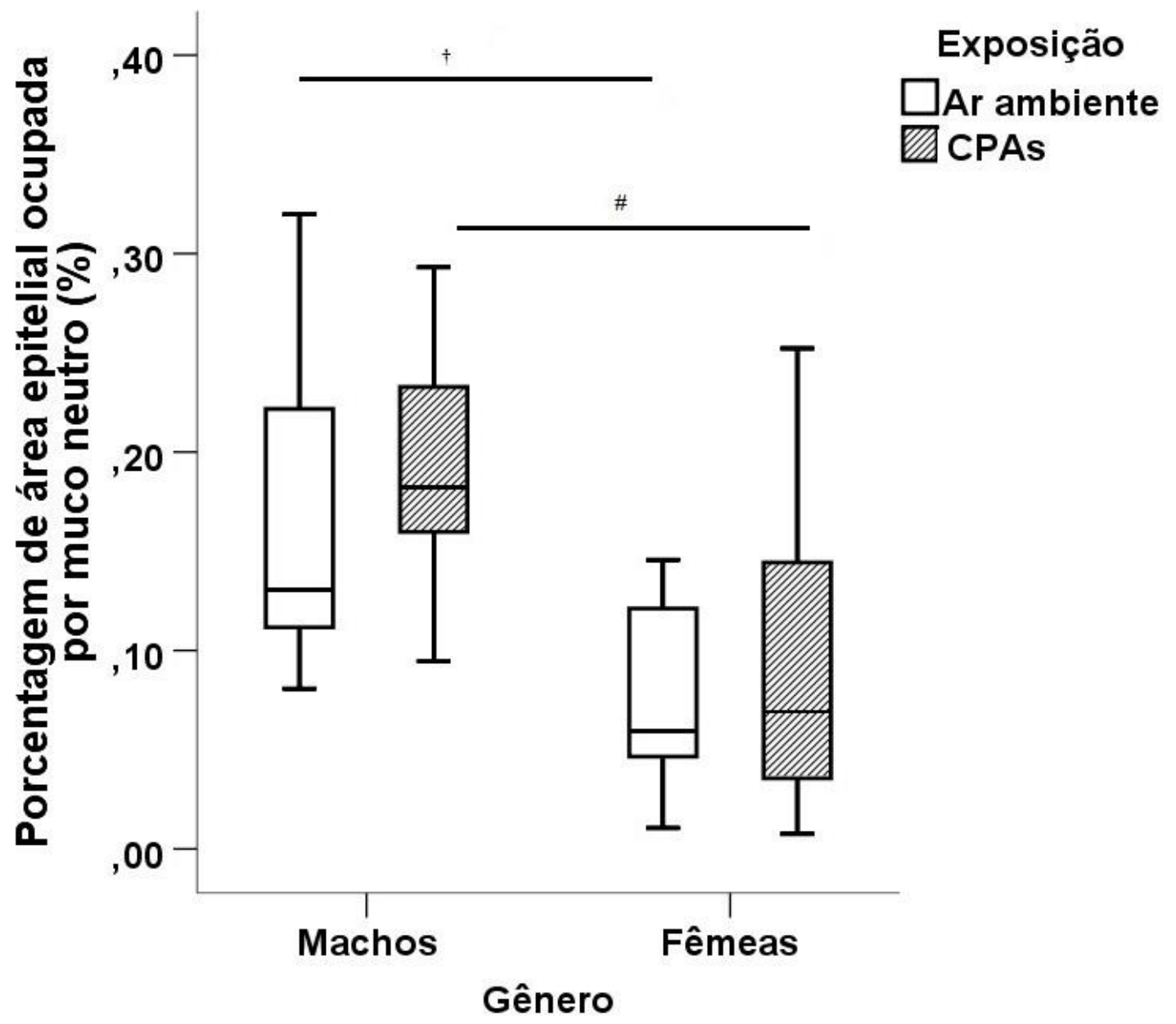

Figura 30. Representação gráfica da expressão de muco neutro no epitélio nasal (porcentagem) de camundongos machos e fêmeas após exposição subcrônica ao ar ambiente e $\mathrm{MP}_{2,5}$ concentrado a $600 \mu \mathrm{g} / \mathrm{m}^{3}$ no CPA. A quantidade expressa de muco neutro no epitélio nasal é maior nos machos quando comparado às fêmeas, expostos em ar ambiente $(\mathrm{p} p=0,048)$ e CPA $(\# p=0,002)$. Valores expressos em "boxplot" (a linha média define a mediana, as bordas acima e abaixo do retângulo representam os percentis $25 \%$ e $75 \%$ respectivamente, e as linhas terminais da barra de erro (abaixo e acima) representam os percentis $10 \%$ e $90 \%$, respectivamente). Camundongos machos expostos ao ar ambiente $(M / A)(n=5)$, camundongos machos expostos ao CPA (M/MP) ( $n=7)$, camundongos fêmeas expostos ao ar ambiente ( $F / A)$ $(n=12)$, camundongos fêmeas expostos ao CPAs (F/MP) $(n=22)$. 
Não foi observada diferença entre fêmeas nas fases dos ciclos estrais, como se vê na Figura 31.

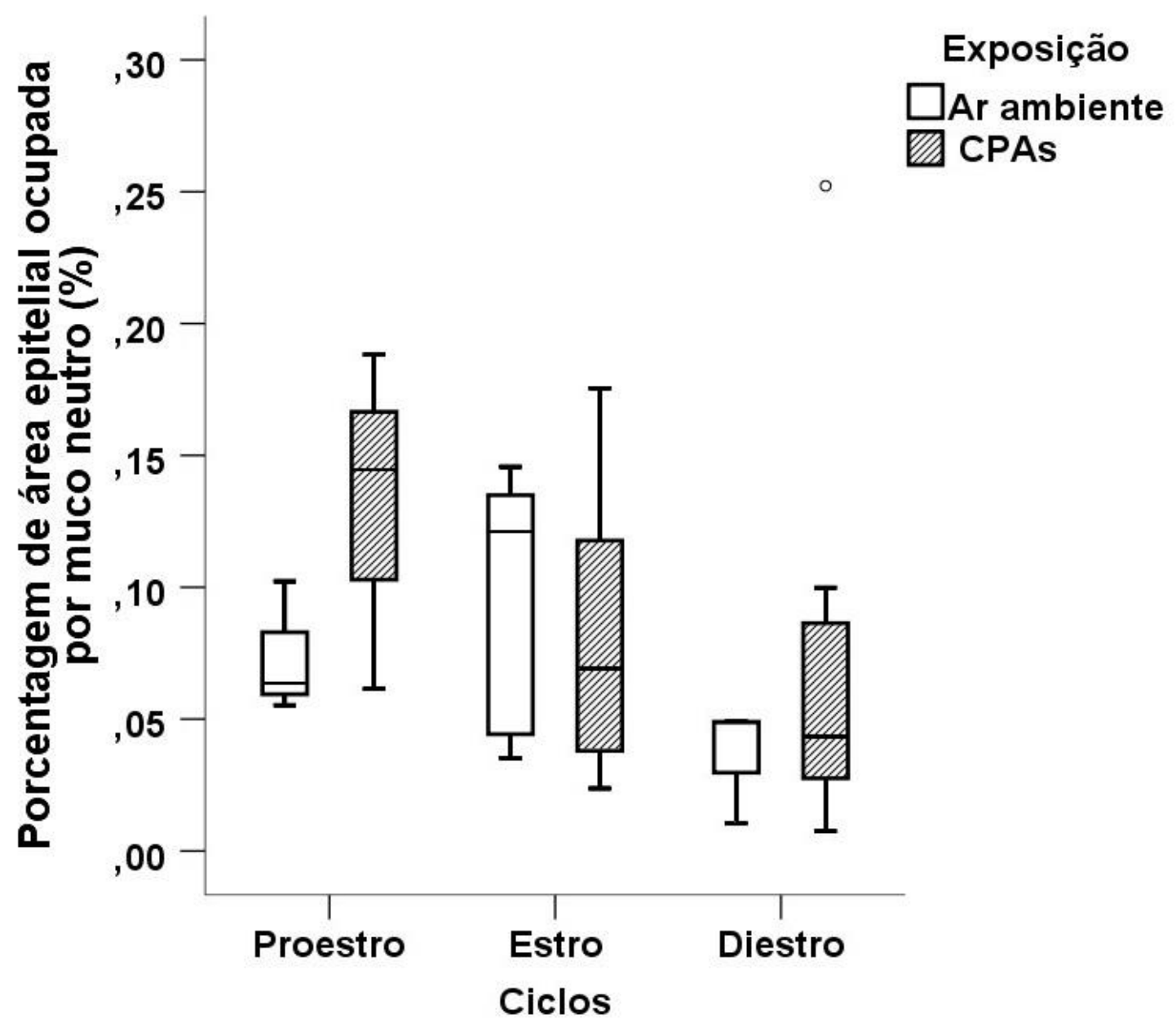

Figura 31. Representação gráfica da expressão de muco neutro no epitélio nasal (porcentagem) de camundongos fêmeas em 3 fases do ciclo estral (proestro, estro e diestro) após exposição subcrônica ao ar ambiente e $\mathrm{MP}_{2,5}$ concentrado a $~ 600 \mu \mathrm{g} / \mathrm{m}^{3}$ no CPAs. Não houve diferença estatística entre os grupos na expressão de muco neutro no epitélio nasal. Valores expressos em "boxplot" (a linha média define a mediana, as bordas acima e abaixo do retângulo representam os percentis $25 \%$ e $75 \%$ respectivamente, e as linhas terminais da barra de erro (abaixo e acima) representam os percentis $10 \% \mathrm{e}$ $90 \%$, respectivamente). Fêmeas nas seguintes fases: proestro, expostas ao ar ambiente (PE/A) ( $n=3)$; proestro, expostas ao CPA (PE/MP) $(n=4)$; estro, expostas ao ar ambiente (E/A) ( $n=6)$; estro, expostas ao CPA (E/MP) $(n=10)$; diestro, expostas ao ar ambiente (D/A) $(n=3)$, e diestro, expostas ao CPA $(\mathrm{D} / \mathrm{MP})(\mathrm{n}=8)$. 
A quantidade de muco ácido expresso no epitélio nasal aumentou nos machos e diminuiu nas fêmeas quando expostos ao CPA. (Figura 32).

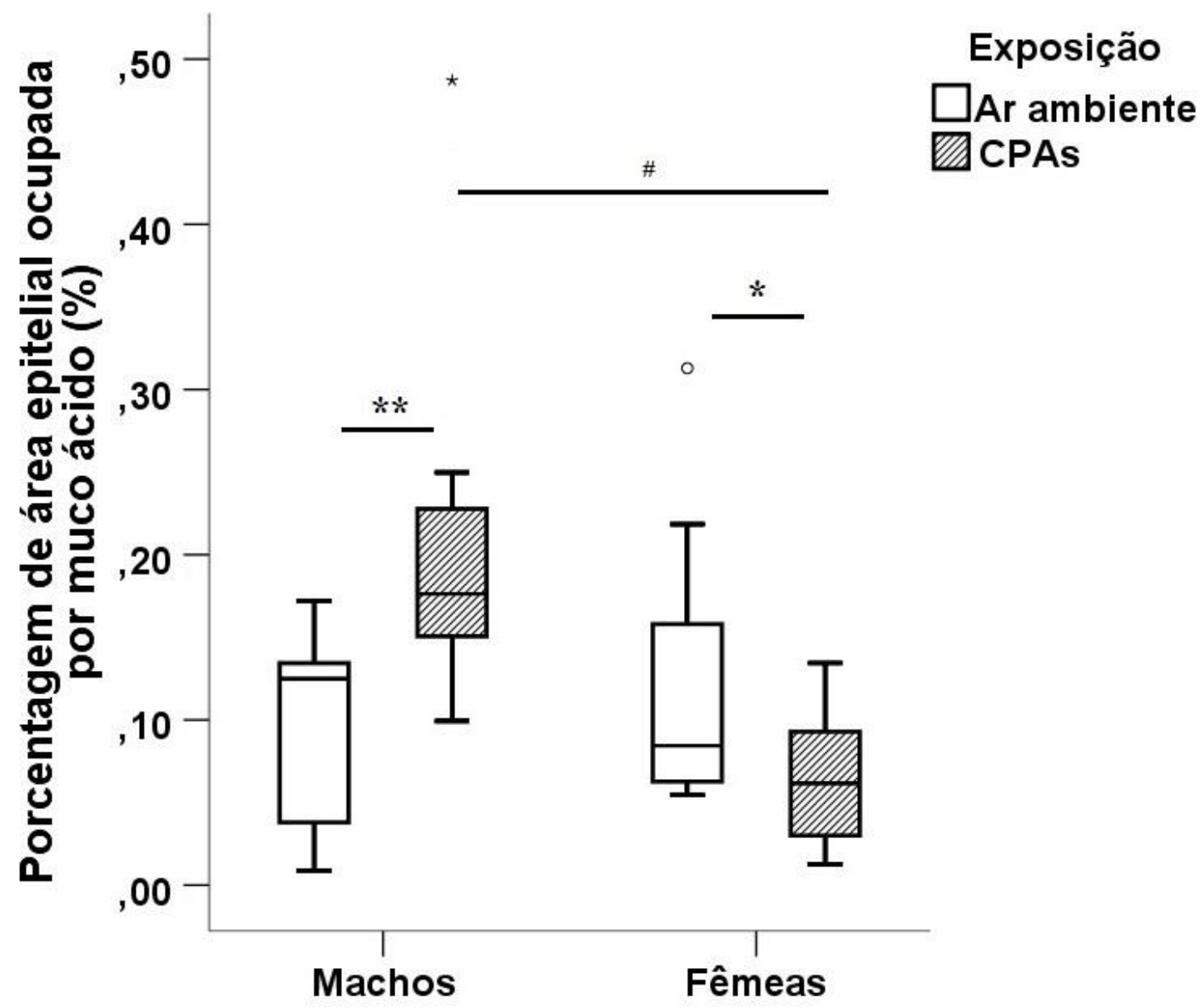

Gênero

Figura 32. Representação gráfica da expressão de muco ácido no epitélio nasal (porcentagem) de camundongos machos e fêmeas após exposição subcrônica ao ar ambiente e $\mathrm{MP}_{2,5}$ concentrado a $\sim 600 \mu \mathrm{g} / \mathrm{m}^{3}$ no CPA. A quantidade de muco ácido expresso no epitélio nasal aumentou nos machos $\left({ }^{*} p=0,048\right)$ e diminuiu nas fêmeas $\left({ }^{*} p=0,040\right)$ quando expostos ao CPA. Na exposição ao CPA, os machos expressam mais muco ácido quando comparados às fêmeas ( $p<0,001)$. Valores expressos em "boxplot" (a linha média define a mediana, as bordas acima e abaixo do retângulo representam os percentis $25 \%$ e $75 \%$ respectivamente, e as linhas terminais da barra de erro (abaixo e acima) representam os percentis $10 \%$ e $90 \%$, respectivamente). Camundongos machos expostos ao ar ambiente $(M / A)(n=5)$, camundongos machos expostos ao CPA (M/MP) $(n=7)$, camundongos fêmeas expostas ao ar ambiente (F/A) ( $n=12)$, camundongos fêmeas expostas ao CPA (F/MP) ( $n=22)$. 
Já nas fêmeas em diestro, a quantidade expressa de muco ácido no epitélio nasal foi menor quando comparado ao das fêmeas em estro quando expostas ao CPA (Figura 33).

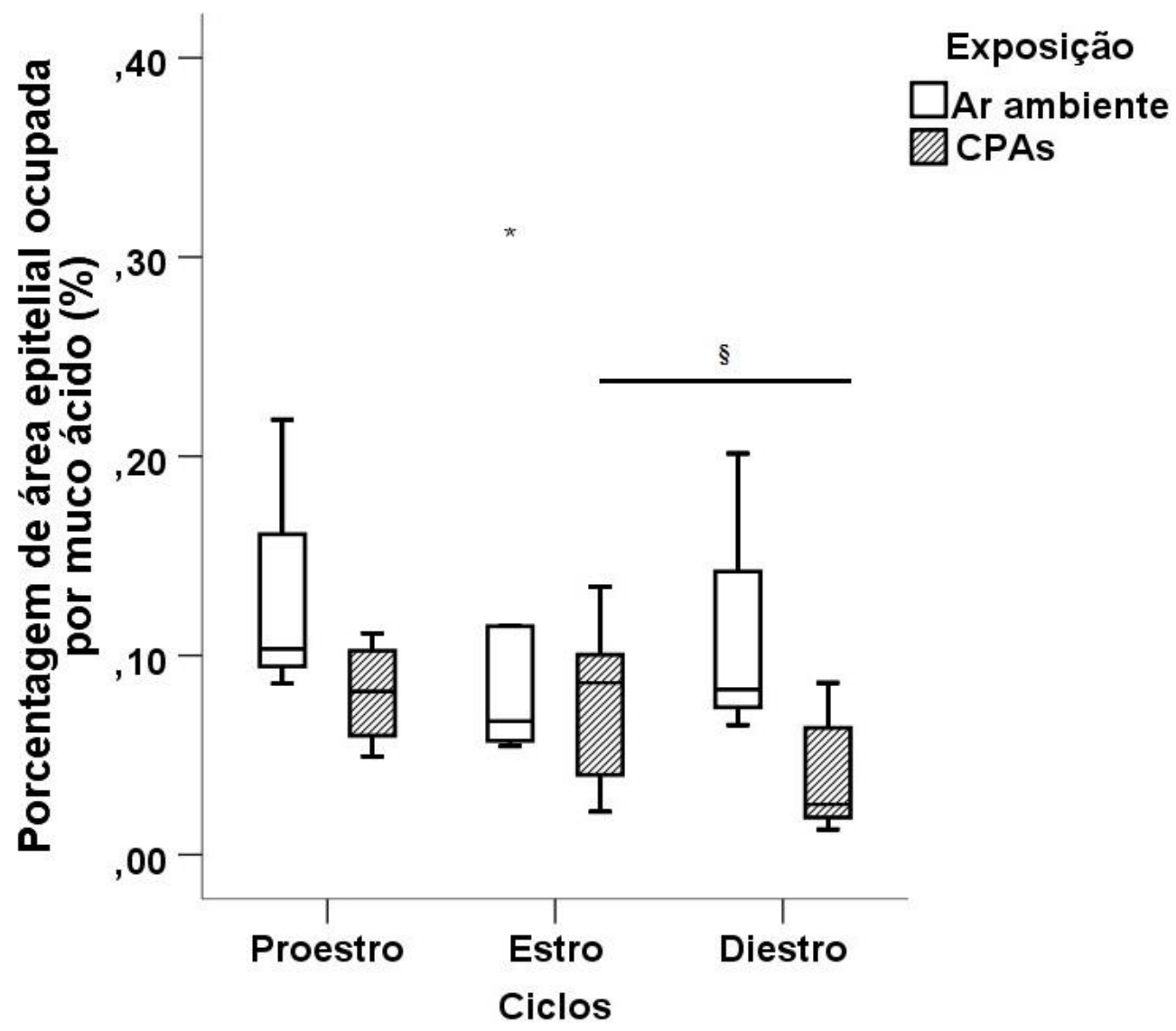

Figura 33. Representação gráfica da expressão de muco ácido no epitélio nasal (porcentagem) de camundongos fêmeas em 3 fases do ciclo estral (proestro, estro e diestro) após exposição subcrônica ao ar ambiente e $\mathrm{MP}_{2,5}$ concentrado a $\sim 600 \mu \mathrm{g} / \mathrm{m}^{3}$ no CPA. A expressão de muco ácido no epitélio nasal de fêmeas é menor em diestro quando comparada ao estro na exposição ao CPA $\left({ }^{\S} \mathrm{p}=0,05\right)$. Valores expressos em "boxplot" (a linha média define a mediana, as bordas acima e abaixo do retângulo representam os percentis $25 \%$ e $75 \%$ respectivamente, e as linhas terminais da barra de erro (abaixo e acima) representam os percentis $10 \%$ e $90 \%$, respectivamente). Camundongos fêmeas nas seguintes fases: proestro, expostos ao ar ambiente $(P E / A)(n=3)$; proestro, expostos ao CPA (PE/MP) ( $n=4)$; estro, expostos ao ar ambiente (E/A) $(n=6)$; estro, expostos ao CPA (E/MP) $(n=10)$; diestro, expostos ao ar ambiente $(D / A)(n=3)$, e diestro, expostos ao CPA (D/MP) $(n=8)$. 


\subsection{Análise da espessura do epitélio nasal}

A espessura média do epitélio nasal foi determinada por meio da distância do limite da membrana basal e o limite de membrana apical da região do epitélio nasal analisado. Observa-se que, após a exposição de $\mathrm{MP}_{2,5}$ concentrado a $600 \mu \mathrm{g} / \mathrm{m}^{3}$ no CPA, aos machos e as fêmeas não apresentam diferença estatística significativa para espessura de epitélio (Figura 34).

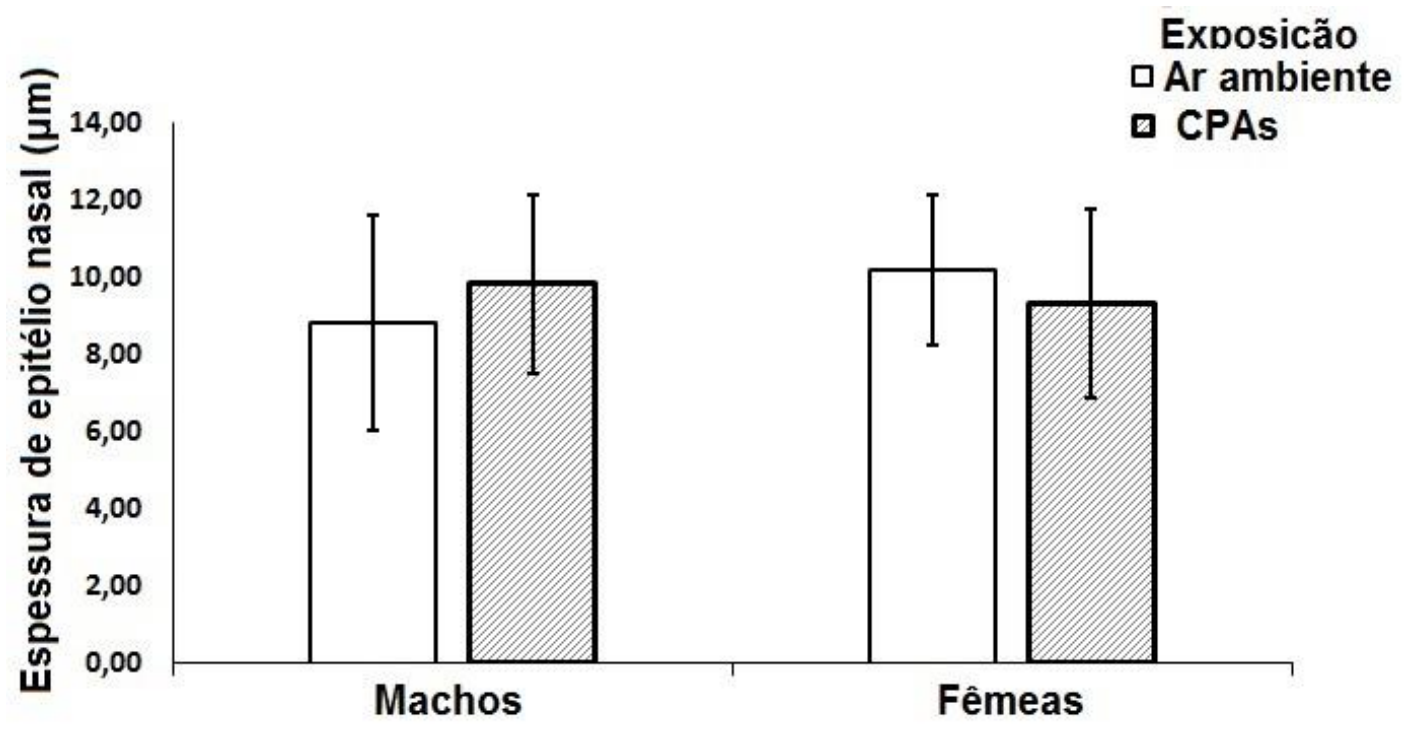

Figura 34. Representação gráfica da espessura do epitélio nasal $(\mu \mathrm{m})$ de camundongos machos e fêmeas após exposição subcrônica ao ar ambiente e $\mathrm{MP}_{2,5}$ concentrado a $\sim 600 \mu \mathrm{g} / \mathrm{m}^{3}$ no CPA. Não houve diferença estatística significativa para espessura de epitélio nasal entre os grupos. As colunas dos gráficos representam a média e o desvio padrão. Camundongos machos expostos ao ar ambiente (M/A) $(n=5)$, camundongos machos expostos ao CPA $(M / M P)(n=7)$, camundongos fêmeas expostos ao ar ambiente (F/A) $(n=12)$, camundongos fêmeas expostos ao CPA (F/MP) $(n=22)$. 
A Figura 35 ilustra essa observação nas 3 fases do ciclo estral.

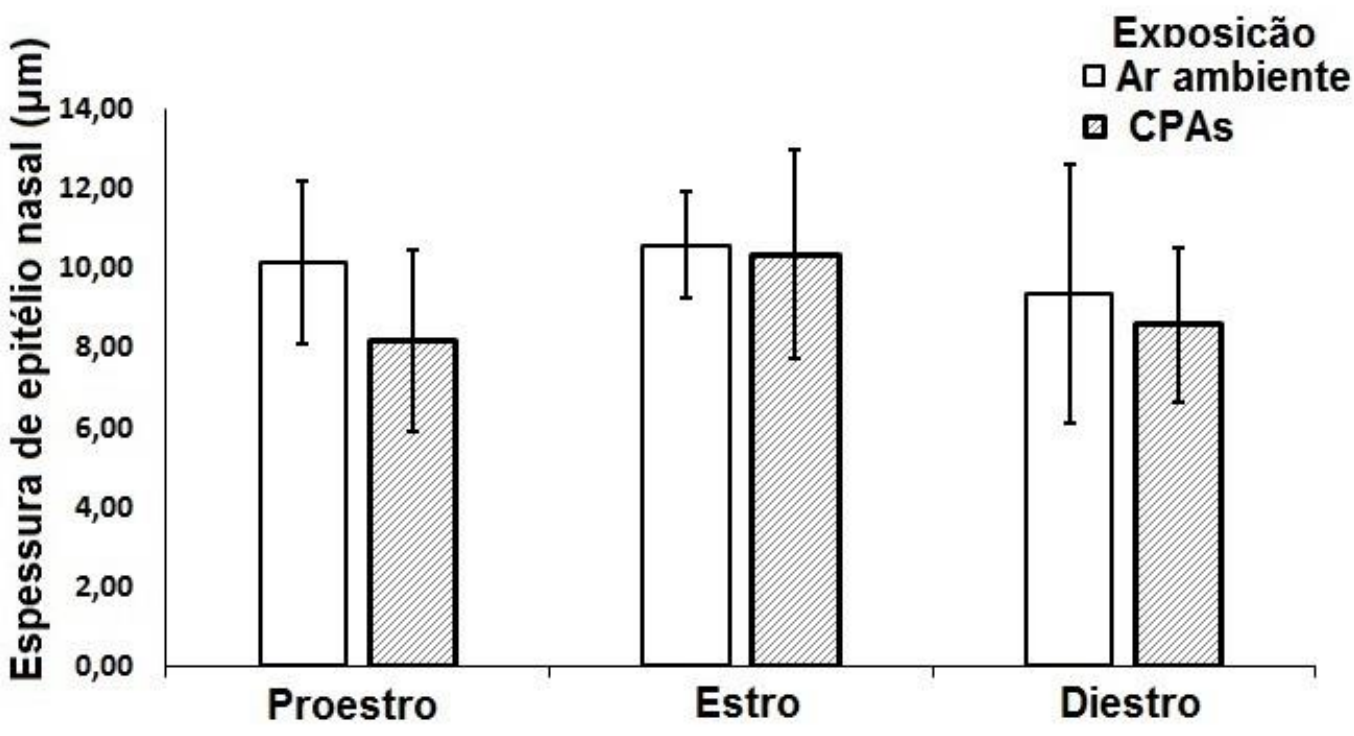

Figura 35. Representação gráfica da espessura do epitélio nasal $(\mu \mathrm{m})$ de camundongos fêmeas em 3 fases do ciclo estral (proestro, estro e diestro) após exposição subcrônica ao ar ambiente e $\mathrm{MP}_{2,5}$ concentrado a $\sim 600 \mu \mathrm{g} / \mathrm{m}^{3}$ no CPA. Não houve diferença estatística significativa para a espessura de epitélio nasal entre os grupos. As colunas dos gráficos representam a média e o desvio padrão. Fêmeas nas seguintes fases: proestro, que foram expostas ao ar ambiente (PE/A) ( $n=3)$; proestro, que foram expostas ao CPA (PE/MP) $(n=4)$; estro, expostas ao ar ambiente (E/A) $(n=6)$; estro, expostas ao CPA (E/MP) $(n=10)$; diestro, expostas ao ar ambiente $(D / A)(n=3)$, e diestro, expostas ao CPA (D/MP) $(n=8)$. 
DISCUSSÃO 


\section{Discussão}

Este estudo demonstrou os efeitos de exposições à poluição do ar nos receptores e enzimas que metabolizam os xenobióticos no epitélio nasal. Essas proteínas são importantes para a mediação do estrógeno e podem estar envolvidas na resposta frente a compostos orgânicos presentes na poluição, principalmente os hidrocarbonetos policíclicos aromáticos, que são geralmente encontrados adsorvidos no material particulado.

As exposições foram realizadas no jardim da Faculdade de Medicina da Universidade de São Paulo (FMUSP), localizada entre a Avenida Doutor Arnaldo e a Rua Teodoro Sampaio, uma região com tráfego intenso de veículos automotores, que também possui um corredor de ônibus, onde são encontrados veículos com diferentes tipos e idades de motor, condições de operação e formulações do combustível. Amostras de material particulado foram coletadas nessa região e analisadas no Instituto de Química da USP para a determinação de compostos orgânicos, tendo sido identificada a presença de Ace (acenafitaleno), Fe (fenantreno), Ant (antraceno), Pireno, BaA (benzo(a)antraceno), Criseno, BbF+BKF (benzo(b)fluoranteno e benzo(k)fluoranteno), BaP (benzo(a)pireno), InP(indeno(1,2,3-cd) pireno) e DBA (dibenzo antraceno). Alguns HPAs, quando hidroxilados, tais como os BaP e criseno, podem ter estrutura molecular semelhante a $17 \beta$-estradiol (Wenger et al., 2009).

Neste trabalho, as amostras coletadas apresentaram níveis mais elevados de HPAs (média $6,11 \mathrm{ng} / \mathrm{m}^{3}$ ) em relação aos achados de Vasconcellos et al. (2003), que foram coletados no ano de 2000 em três diferentes localizações na região metropolitana de São Paulo: 1) na Cidade 
Universitária, onde a amostragem foi realizada a aproximadamente 2 quilômetros de uma das principais vias de intenso tráfego de veículos movidos à gasolina e álcool, diesel e etanol (média $3,10 \mathrm{ng} / \mathrm{m}^{3}$ ); 2) na Água Funda, região de grande vegetação e a 20 quilômetros de Cubatão, uma região com várias fontes de emissão de áreas petroquímicas e da refinaria de petróleo (média 2,73 ng/m³), e 3) em Cotia, uma região de vegetação, onde a amostragem foi feita a 15 quilômetros de uma estrada de fluxo de veículos pesados movidos a diesel (média 1,92 $\mathrm{ng} / \mathrm{m}^{3}$ ). Vasconcelos et al. (2003) relataram a relativa abundância de benzo[b]fluoranteno e criseno em ambiente localizado perto de estradas com tráfego intenso de veículos a diesel, sugerindo que esses veículos correspondem às maiores fontes desses HPAs.

Nossos resultados também mostraram que criseno, pireno e benzo[a]antraceno corresponderam aos maiores níveis de HPAs coletados na região onde aconteceram as exposições dos animais, sendo que a grande concentração de veículos movidos a diesel nessa região poderia explicar o alto nível de HPAs. Evidências de que compostos estrogênicos estão presentes nas partículas da atmosfera foram relatadas pela primeira vez por Zacharewski et al. (1998), sendo mais tarde confirmadas por dois estudos in vitro a hipótese de que os hidroxi-HPAs podem contribuir para a atividade estrogênica (Wang et al., 2004; Klein et al., 2006). Os hidroxi-HPAs são formados na atmosfera pela oxidação secundária de HPAs na fase gasosa, sendo geralmente menos voláteis do que os HPAs de origem, e tendem a se associar melhor com o material particulado (Vione et al., 2004). Hidroxi-HPAs e seus precursores são gerados por processos atmosféricos e diretamente por processos de combustão, sendo encontrados, por exemplo, na exaustão do motor a diesel 
(Sidhu et al., 2005; Heeb et al., 2008). Além disso, os HPAs-hidroxilados podem ser formados no organismo após a ingestão de HPA parenteralmente, por biotransformação catalisada pelo citocromo P450 (CYP) (Charles et al., 2000; Fertuck et al., 2001; van Lipzig et al., 2005). A estrogenicidade in vitro pode ser observada em certos HPAs, e ocorre supostamente devido a metabólitos hidroxilados formados em células expostas (Charles et al., 2000; Fertuck et al., 2001; Lipzig van et al., 2005).

Há trabalhos que relatam a presença e a participação dos Era e Erß no tecido pulmonar, os quais são importantes para a formação de alvéolos em fêmeas e a modulação do desenvolvimento da matriz extracelular, o que permite a pressão de recuo normal do tecido elástico pulmonar (Massaro; Massaro, 2004). Estudos que mostram a presença de receptores de estrógenos no epitélio nasal são poucos e estão relacionados com a sua distribuição, a fim de caracterizar a influência de hormônios, como o uso de pílulas anticoncepcionais, em processos fisiopatológicos nasais que não são totalmente compreendidos. A literatura apresenta estudos que mostram a associação entre variação hormonal e condição nasal, como a influência do estrógeno e a incidência de congestão nasal em mulheres gestantes (Hamano et al., 1998).

O presente estudo investigou as diferenças na expressão de duas isoformas de receptores de estrógeno, $\operatorname{Er} \beta-1$ e $\operatorname{Er} \beta-2$, no epitélio nasal, em relação ao gênero, e nas três fases do ciclo estral de camundongos fêmeas expostos ao ar ambiente e ao $\mathrm{MP}_{2,5}$ concentrado a aproximadamente 600 $\mu \mathrm{g} / \mathrm{m}^{3}$. Observou-se que houve diferenças entre os gêneros em Erß-2 RNAm, em resposta à exposição ao CPA $(p=0,036)$, com diminuição da expressão de 
Erß-2 RNAm em camundongos fêmeas. Também se observou que a poluição interfere na expressão gênica do Erß-2 de camundongos fêmeas, principalmente na fase diestro $(p=0,008)$. Essa fase é definida por baixo nível circulante de estrogênio no organismo, mas com maior abundância do receptor de estrógeno (Wu et al., 1996; Berisha et al., 2002). Na fase diestro, a exposição ao CPA ocasiona uma diminuição da expressão do RNAm para o $E R \beta$, o que poderia ser explicado pelos compostos similares ao estrógeno resultantes dos compostos orgânicos da poluição do ar. Por sua vez, na fase estro, foi observado um aumento de Erß por exposição ao CPA $(p=0,005)$, sugerindo que o equilíbrio entre o estrogênio e o seu receptor foi alterado (Kuiper et al., 1998).

No presente estudo foi observada uma maior expressão gênica de AhR RNAm no epitélio nasal do que de seus competidores Erß-1 e Erß-2, porém sem diferença pela exposição e pelo gênero; na fase estro, a área imunomarcada por imuno-histoquímica revelou uma diminuição da expressão de proteínas do $\mathrm{AhR}(\mathrm{p}=0,002)$ em resposta à exposição ao ar ambiente. $\mathrm{Na}$ fase proestro, houve uma diminuição da expressão de proteínas do AhR $(p=0,048)$ no grupo exposto ao CPA, em comparação ao grupo ar ambiente .

O AhR é conhecido por estar envolvido na imunorregulação alérgica, como relatado por Bettelli et al. (2008), que mostrou que os HPA e 2,3,7,8 tetraclorodibenzo-p-dioxina (TCDD) aumentam a produção de imunoglobulina $E$ ( $\lg E)$ em culturas purificadas com células B. O AhR é um fator de transcrição induzido por ligante, que regula a diferenciação celular e indução de enzimas de biotrasformação, com papel na resposta a poluentes tóxicos ambientais, como dioxinas (2,3,7,8-tetraclorodibenzeno-p-dioxina - TCDD) ou HPAs. 
Estudos bioquímicos e genéticos indicam que a maioria das respostas obtidas por HPAs é devida à ligação ao AhR. Por exemplo, há evidência mostrando que a correlação entre ER e sistemas AhR levam à inibição da sinalização do estrógeno, tanto in vitro como em estudos experimentais em animais (Safe; Wormke, 2003). Outros estudos utilizando agonistas e inibidores AhR demonstraram que a ativação de AhR induziu a produção de citocinas como TGF- $\alpha$, TNF- $\alpha$ e receptores de MMP por eritrócitos humanos e células epiteliais. O AhR também regula a expressão de moléculas de adesão e, assim, controla o contato célula-célula. (Buters et al., 2002; Shimada, FujiiKuriyama, 2004; Nukaya et al., 2009; Ishida et al., 2010).

A ativação do AhR regula a expressão dos genes fundamentais do citocromo P450 (por exemplo, CYP1A1, CYP1A2 e CYP1B1), que promovem a eliminação de $17 \beta$-estradiol (E2) e estrona (E1), dois ligantes predominantes do receptor de estrogênio (Lee et al., 2003). No presente estudo, observamos que a exposição ao $\mathrm{MP}_{2,5}$ concentrado altera a expressão de gênica de Cyp1b1 no epitélio nasal nas diferentes fases do ciclo estral de camundongos fêmeas. As fêmeas em proestro e diestro diminuíram a expressão gênica de Cyp $1 b 1$ em comparação àquelas em estro $(p=0,01)$. Foi observado que, no ciclo diestro, quando o nível circulante de estrógeno é baixo, a exposição ao $\mathrm{MP}_{2,5}$ concentrado no CPA altera, diminuindo a expressão gênica de Cyp1b1 em comparação à exposição ao ar ambiente $(\mathrm{p}=0,036)$.

Nas fases do ciclo estral, enquanto a expressão gênica de Cyp1a2 foi estatisticamente diferente em fêmeas expostas ao CPA e ao ar ambiente $(p=0,013$ e $p=0,015$ respectivamente), na fase diestro houve uma diminuição 
da expressão do Cyp1a2 por CPA em relação à exposição ao ar ambiente $(p=0,05)$.

Pela via AhR (Rusmore; Kong, 2002), o CYP1B1 metaboliza os constituintes da fumaça de tabaco, como os HPAs [benzo(a)pireno (BaP)] e a principal enzima responsável pela geração de catecois de estrógenos, os quais apresentam a propriedade de danificar macromoléculas por formação de radicais livres (Siegfried , 2010). Meireles et al. (2010) observaram um aumento de expressão de CYP1B1 em tecido pulmonar de camundongos, após períodos de exposição de 3, 8 e 20 semanas à fumaça de cigarro.

A CYP1B1, uma enzima da fase 1, é capaz de metabolizar o estradiol em compostos potencialmente mutagênicos e/ou carcinogênicos (Liehr; Ricci, 1996), além de bioativar HPAs presentes na fumaça de cigarro, como o benzo(a)pireno, a potenciais carcinógenos (Shimada et al., 1996).

A CYP1A1 contribui para o metabolismo do $\mathrm{BaP}$ e do estrógeno (Siegfried, 2010). Alguns estudos demonstram que uma pequena exposição à fumaça de cigarro induz a expressão de CYP1A1 e CYP1A2. Raza et al. (2013) demonstraram que, após 4 dias de exposição à fumaça de cigarro, houve aumento na atividade e expressão de CYP1A1 e CYP1A2 nos tecidos pulmonar, hepático, renal e cardíaco de camundongos. O presente trabalho demonstrou a expressão de AhR, CYP1A1, CYP1A2 e CYP1B1 no epitélio nasal, confirmando a existência de um sistema metabólico relevante nesse tecido.

A atividade da enzima hepática P450 foi elevada em ratos machos, em relação às fêmeas, em estudo realizado por Watanabe et al. (1997); por sua vez, o conteúdo microssomal total da P450 foi também encontrado elevado em 
ratos machos, em relação ao das fêmeas (Guo et al., 1993). No presente estudo foi observada similar expressão de Cyp1a1 Cyp1a2, Cyp1b1 no epitélio nasal de ambos os gêneros.

Pouco se sabe sobre o efeito de hormônios circulantes e/ou seus receptores hormonais no metabolismo dos xenobióticos nas vias aéreas.

O presente estudo observou, no epitélio nasal, um aumento de muco ácido e neutro em camundongos machos, em relação às fêmeas, quando da exposição ao CPA ( $p=0,001$ e $p=0,002$ respectivamente). Uma maior quantidade de muco neutro foi observada em camundongos machos, em relação às fêmeas $(p=0,048)$, por exposição ao ar ambiente. No entanto, não houve alteração na espessura do epitélio nasal, tanto em machos quanto em fêmeas, por exposição ao ar ambiente ou CPA. Saldiva et al. (1995) demonstrou diferenças entre ratos machos e fêmeas, com relação ao muco ácido as fêmeas em estro apresentaram menor quantidade de muco quando comparado aos machos.

O epitélio nasal é o primeiro a entrar em contato com o ar ambiente, devendo estar preparado para atuar como barreira para diversas impurezas, prevenindo sua entrada no aparelho respiratório. Para esse propósito, as células mucosas podem produzir muco mais espesso (ácido) em ambiente poluído, de maneira a evitar a infiltração de substâncias nas células epiteliais. Kato e Kagawana (2003) demonstraram que roedores expostos ao ar presente em tráfego rodoviário, por 24 e 48 semanas, apresentaram proliferação de células mucosas nas vias aéreas, associada à acidificação dos grânulos mucosos em tais células. 
A acidificação do muco modifica as propriedades físico-químicas das mucinas, podendo levar ao aumento de sua viscosidade e a edema celular, interferindo na integridade do sistema mucociliar e, consequentemente, provocando alterações nos mecanismos de defesa do epitélio respiratório (Giddens, Fairchild, 1972; Holma, 1989; Daviskas, Anderson, 2006; Li et al., 2007). Esses achados suportam a idéia que a exposição ao $\mathrm{MP}_{2,5}$ concentrado no CPA é capaz de induzir aumento de muco ácido no epitélio nasal de camundongos machos, demonstrando que os camundongos machos expostos ao CPA apresentam maior resposta aos insultos externos do que as fêmeas.

O presente estudo também observou a presença de duas isoformas do $\operatorname{Er} \beta$ (Erß-1 e Erß-2), Ahr e enzimas CYP (Cyp1a1, Cyp1a2 e Cyp1b1) no epitélio nasal de camundongos machos e fêmeas, relacionadas à poluição ambiental. Em acordo com os resultados encontrados, pode-se concluir que, na cidade de São Paulo, elevados níveis de HPAs são encontrados, os quais podem influenciar o papel do ER $\beta$ nas fases do ciclo estral. Este trabalho observou um decréscimo de Erß-2 RNAm e Cyp1a2, principalmente na fase diestro, quando da exposição de fêmeas ao CPA; por outro lado, foi observado um aumento de Cyp1b1 na fase estro. Existem diferentes respostas no epitélio nasal de camundongos machos e fêmeas em relação à exposição à poluição do ar, sendo que essas diferenças podem ser relacionadas à predisposição de fêmeas a apresentar maior susceptibilidade às doenças do trato respiratório. 
CONCLUSÃO 


\section{Conclusão}

Este trabalho verificou a presença de elevados níveis de HPAs na cidade de São Paulo, que podem influenciar o papel do ERß nas fases do ciclo estral de camundongos fêmeas.

A exposição à poluição do ar afeta a expressão de proteínas e genes de camundongos, a qual é importante na mediação do estrógeno e de compostos orgânicos presentes na poluição do ar.

Existem diferentes mecanismos de defesa do epitélio nasal à exposição à poluição do ar entre camundongos machos e fêmeas, sendo que o epitélio nasal dos primeiros apresentou aumento na expressão de muco e essa diferença pode ser relacionada à predisposição de fêmeas a apresentar maior susceptibilidade às doenças do trato respiratório. 
REFERÊNCIAS 


\section{Referências}

Arruda LK, Solé D, Baena-Cagnani CE, Naspitz CK. Risk factors for asthma and atopy. Curr Opin Allergy Clin Immunol. 2005;5(2):153-9.

Becker JB, Arnold AP, Berkley KJ, Blaustein JD, Eckel LA, Hampson E, Herman JP, Marts S, Sadee W, Steiner M, Taylor J, Young E. Strategies and methods for research on sex differences in brain and behavior. Endocrinology. 2005;146(4):1650-73.

Bende M, Gredmark T. Nasal stuffiness during pregnancy. Laryngoscope. 1999;109:1108-1110.

Berisha B, Pfaffl MW, Schams D. Expression of estrogen and progesterone receptors in the bovine ovary during estrous cycle and pregnancy. Endocrine. 2002;17(3):207-214.

Bettelli E, Korn T, Oukka M, Kuchroo VK. Induction and effector functions of $\mathrm{T}(\mathrm{H}) 17$ cells. Nature. 2008;453(7198):1051-1057.

Buters JT, Mahadevan B, Quintanilla-Martinez L, Gonzalez FJ, Greim H, Baird WM, et al. Cytochrome P450 1B1 determines susceptibility to dibenzo[a,I]pyrene-induced tumor formation. Chem Res Toxicol. 2002;15:11271135.

Caracta CF. Gender differences in pulmonary disease. Mt Sinai J Med. 2003;70:215-224.

Camargo Pires-Neto R, Júlia Lichtenfels A, Regina Soares S, Macchione M, Hilário Nascimento Saldiva $P$, Dolhnikoff M. Effects of São Paulo air pollution on the upper airways of mice. Environ Res. 2006 Jul;101(3):356-61.

Centers for Disease Control and Prevention: Asthma prevalence, health care use and mortality. 2010 [http://www.cdc.gov/nchs/data/hestat/asthma/asthma.htm]. Date last updated: Feb 3 2010. Date last accessed: Feb 3.

CETESB (Companhia de Tecnologia de Saneamento Ambiental). 2012. Relatório de qualidade do ar do estado de São Paulo 2012. Série RelatórioSecretaria do Estado do Meio Ambiente. São Paulo: CETESB. Available: http//:www.cetesb.sp.gov.br/ar/qualidade-do-ar/31-publicacoes-e-relatorios.

Charles GD, Bartels MJ, Zacharewski TR, Gollapudi BB, Freshour NL, Carney EW. Activity of benzo[a]pyrene and its hydroxylated metabolites in an estrogen receptor-alpha reporter gene assay. Toxicol Sci. 2000;55(2):320-326.

Chomczynski \& Sacchi. Single-step method of RNA isolation by acid guanidinium thiocyanate-phenol-chloroform extraction. Anal Biochem. 1987; 162(1):156-159. 
Chopra M, Schrenk D. Dioxin toxicity, aryl hydrocarbon receptor signaling, and apoptosis-persistent pollutants affect programmed cell death. Crit Rev Toxicol. 2011 Apr;41(4):292-320.

Clemons JH, Allan LM, Marvin CH, Wu Z, McCarry BE, Bryant DW,Zacharewski TR.. Evidence of estrogen- and TCDD-like activitiesin crude and fractionated extracts of PM10 air particulate materialusing in vitro gene expression assays. Environ. Sci. Technol.1998;32:1853-1860.

Conney $\mathrm{AH}$. Induction of microsomal enzymes by foreign chemicals and carcinogenesis by polycyclic aromatic hydrocarbons: G. H. A. Clowes Memorial Lecture. Cancer Research. 1982;42:4875-4917.

Damstra T, Barlow S, Bergman A, Kavlock R, Van Der Kraak G. 2002. Global Assessment of the State-of-the-science of Endocrine Disruptors. World Health Organization (WHO), International Labour Organisation (ILO), United Nations Environment Programme (UNEP). Available at: http:// www.who.int/ipcs/publications/new_issues/endocrine_disruptors/en/.

Daviskas, E, Anderson, SDJ. Hyperosmolar agents and clearance of mucus in the diseased airway. Aerosol. Med. Spring. 2006;19(1):100-109.

De Rosa M, Zarrilli S, Paesano L, Carbone U, Boggia B, Petretta M, Maisto A, Cimmino F, Puca G, Colao A, Lombardi G. Traffic pollutants affect fertility in men. Hum. Reprod. 2003;18:1055-1061.

Denison MS, Fisher JM, Whitlock JP Jr. Inducible, receptor-dependent proteinDNA interactions at a dioxin-responsive transcriptional enhancer. Proc Natl Acad Sci U S A. 1988 Apr;85(8):2528-32.

Delfino RJ, Sioutas C, Malik S. Potential role of ultrafine particles in associations between airborne particle mass and cardiovascular health. Environ. Health Perspect. 2005;113:934-946.

Ellegard E, and Karlsson G. Nasal congestion during pregnancy. Clin Otolaryngol Allied Sci. 1999; 24:307-311.

Farina F, Colombi S, Cantone R, Pastore M, Centanni S, Galimberti M. Study of hypophyseal and gonadal hormones and cases of postmenopausal occurrence of bronchial asthma. Minerva Med. 1996;77:243-237.

Fernandez-Salguero PM, Ward JM, Sundberg JP, Gonzalez FJ. Lesions of arylhydrocarbon receptor-deficient mice. Vet Pathol. 1997 Nov;34(6):605-614.

Fertuck KC, Matthews JB, Zacharewski TR. Hydroxylated benzo[a]pyrene metabolites are responsible for in vitro estrogen receptor-mediated gene expression induced by benzo[a]pyrene, but do not elicit uterotrophic effects in vivo. Toxicol. Sci. 2001;59: 231-240.

Giangrande P, Macdonnel DP. The A and B isoforms of the human progesterone receptor: two functionally different transcription factors encoded by a single gene. Rec Prog Horm. Res. 1999;54, 291-314. 
Giddens WE Jr, Fairchild GA. Effects of sulfur dioxide on the nasal mucosa of mice. Arch Environ Health. 1972 Sep;25(3):166-173.

Gillum RF. Frequency of attendance at religious services and cigarette smoking in American women and men: the Third National Health and Nutrition Examination Survey. Prev Med. 2005;41:607-613.

Guo Z, Wang M, Tian G, Burger J, Gochfeld M, Yang CS. Age- and genderrelated variations in the activities of drug-metabolizing and antioxidant enzymes in the white-footed mouse (Peromyscus leucopus). Growth Dev Aging. Summer. 1993;57(2):85-100.

Hamano N, Terada N, Maesako K, et al. Expression of histamine receptors in nasal epithelial cells and endothelial cells-The effects of sex hormones. Int Arch Allergy Immunol. 1998;115:220-227.

Han MK, Postma D, Mannino DM, Giardino ND, Buist S, Curtis JL, Martinez FJ. Gender and chronic obstructive pulmonary disease: why it matters. Am J Respir Crit Care Med. 2007;176:1179-1184.

Hayakawa K, Onoda Y, Tachikawa C, Hosoi S, Yoshita M, Chung SW, Kizu R, Toriba A, Kameda T, Tang N. Estrogenic/antiestrogenic activities of polycyclic aromatic hydrocarbons and their monohydroxylated derivatives by yeast twohybrid assay. J. Health Sci. 2007;53: 562-570.

Herbert RA, Leininger JR. Nose, larynx and trachea. In: Maronpot, R.R. (Ed.), Pathology of the Mouse: Reference and Atlas. 1999.pp.259-292.

Heeb NV, Schmid P, Kohler M, Gujer E, Zennegg M, Wenger D, et al. Secondary effects of catalytic diesel particulate filters: conversion of PAHs versus formation of nitro-PAHs. Environ Sci Technol. 2008;42(10):3773-3779.

Hillegass JM, Murphy KA, Villano CM, White LA. The impact of aryl hydrocarbon receptor signaling on matrix metabolism: implications for development and disease. Biol Chem. 2006 Sep;387(9):1159-1173.

Holma B. Effects of inhaled acids on airway mucus and its consequences for health. Environ Health Perspect. 1989 Feb;79:109-113.

Holmes TH, Goodell H, Wolf S, et al. The Relation of Nasal to Sexual Function in the Nose: An Experimental Study of Reactions within the Nose in Human Subjects during Varying Life Experiences. Springfield, IL: Charles C Thomas, 1950;89-100.

Ishida M, Mikami S, Kikuchi E, Kosaka T, Miyajima A, Nakagawa K, et al. Activation of the Aryl hydrocarbon receptor pathway enhances cancer cell invasion by up-regulating the MMP expression and is associated with poor prognosis in upper urinary tract urothelial cancer. Carcinogenesis. 2010;31:287- 295.

Iba MM, Alam J, Touchard C, Thomas PE, Ghosal A, Fung J. Coordinate upregulation of CYP1A1 and heme oxygenase-1 (HO-1) expression and modulation of delta-aminolevulinic acid synthase and tryptophan pyrrolase 
activities in pyridine-treated rats. Biochem Pharmacol. 1999 Aug 15;58(4):72334.

Iba MM, Fung J, Giannone JV, Okey AB. Comparative induction of CYP1A1 expression by pyridine and its metabolites. Arch Biochem Biophys. 2000 Jun 15;378(2):299-310.

loannides C, Parke DV. Induction of cytochrome P4501 as an indicator of potential chemical carcinogenesis. Drug Metab Rev. 1993;25(4):485-501.

Karavalakis G, Fontaras G, Ampatzoglou D, Kousoulidou M, Stournas S, Samaras Z, Bakeas E. Effects of low concentration biodiesel blends application on modern passenger cars. Part 3: impact on $\mathrm{PAH}$, nitro-PHA, and oxy-PAH emissions. Environ Poll. 2010;158:1584-1594.

Kato A, Kagawa J. Morphological effects in rat lungs exposed to urban roadside air Inhalation. Toxicology. 2003;15:799-818.

Klein GP, Hodge EM, Diamond ML, Yip A, Dann T, Stern G, et al. Gas-phase ambient air contaminants exhibit significant dioxin-like and estrogen-like activity in vitro. Environ Health Perspect. 2006;114:697-703.

Konno A, Terada N, Okamoto Y. Effects of female hormones on the muscarinic and alpha 1-adrenergic receptors of the nasal mucosa. An experimental study in guinea pigs. ORL J Otorhinolaryngol Relat Spec. 1986;48:45-51.

Kroemer HK, Eichelbaum M. "It's the genes, stupid". Molecular bases and clinical consequences of genetic cytochrome P450 2D6 polymorphism. Life Sci. 1995;56(26):2285-98.

Kuiper GG, Lemmen JG, Carlsson B, et al. Interaction of estrogenic chemicals and phytoestrogens with estrogen receptor â. Endocrinology. 1998;139:42524263.

Kurebayashi S, Miyashita Y, Hirose T, Kasayama S, Akira S, Kishimoto T. Characterization of mechanisms of interleukin- 6 gene repression by estrogen receptor. J Steroid Biochem Mol Biol. 1997 Jan;60(1-2):11-7.

Lee AJ, Cai MX, Thomas PE, Conney AH, Zhu BT. Characterization of the oxidative metabolites of 17 beta-estradiol and estrone formed by 15 selectively expressed human cytochrome p450 isoforms. Endocrinology. 2003;144:33823398.

Li R, Meng Z, Xie J. Effects of sulfur dioxide on the expressions of MUC5AC and ICAM-1 in airway of asthmatic rats. Regul Toxicol Pharmacol. 2007;48(3):284-291.

Lichtenfels AJ, Gomes JB, Pieri PC, El Khouri Miraglia SG, Hallak J, Saldiva $\mathrm{PH}$. Increased levels of air pollution and a decrease in the human and mouse male-to-female ratio in São Paulo, Brazil. Fertil Steril. 2007 Jan;87(1):230-2.

Liehr JG, Ricci MJ. 4-Hydroxylation of estrogens as marker of human mammary tumors. Proc Natl Acad Sci U S A. 1996;16,93(8):3294-3296. 
Ma Q, Lu AY. CYP1A induction and human risk assessment: an evolving tale of in vitro and in vivo studies. Drug Metab Dispos. 2007 Jul;35(7):1009-1016.

Machado MC, Krishnan JA, Buist SA, Bilderback AL, Fazolo GP, Santarosa MG, Queiroga F Jr, Vollmer WM. Sex differences in survival of oxygendependent patients with chronic obstructive pulmonary disease. Am J Respir Crit Care Med. 2006;174:524-9.

Mackenzie J. The physiological and pathological relations between the nose and the sexual apparatus of man. Alienist Neurol. 1898;19:219-239.

Mandal PK. Dioxin: a review of its environmental effects and its aryl hydrocarbon receptor biology. J Comp Physiol B. 2005 May;175(4):221-230.

Marcondes FK, Bianchi FJ, Tanno AP. Determination of the estrous cycle phases of rats: some helpful considerations. Braz J Biol. 2002;62(4A):609-614.

Massaro D, Massaro GD. Estrogen regulates pulmonary alveolar formation, loss, regeneration in mice. Am J Physiol Lung Cell Mol Physiol. 2004;287:L1154-L1159.

McLean AC, Valenzuela N, Fai S, Bennett SA. Performing vaginal lavage, crystal violet staining, and vaginal cytological evaluation for mouse estrous cycle staging identification. $J$ Vis Exp. 2012;15(67):e4389,1-6.

Meireles SI, Esteves GH, Hirata R Jr, Peri S, Devarajan K, Slifker M, et al. Early changes in gene expression induced by tobacco smoke: Evidence for the importance of estrogen within lung tissue. Cancer Prev Res. 2010;3(6):707-717.

Mohallem SV, de Araújo Lobo DJ, Pesquero CR, Assunção JV, de Andre PA, Saldiva $\mathrm{PH}$, Dolhnikoff M. Decreased fertility in mice exposed to environmental air pollution in the city of Sao Paulo. Environ Res. 2005 Jun;98(2):196-202.

Morrissey RE, Schwetz BA, Lamb JC 4th, Ross MD, Teague JL, Morris RW. Evaluation of rodent sperm, vaginal cytology, and reproductive organ weight data from National Toxicology Program 13-week studies. Fundam Appl Toxicol. 1988b;11(2):343-58.

Morrissey RE, Lamb JC 4th, Schwetz BA, Teague JL, Morris RW. Association of sperm, vaginal cytology, and reproductive organ weight data with results of continuous breeding reproduction studies in Swiss (CD-1) mice. Fundam Appl Toxicol. 1988a;11(2):359-71.

National Toxicology Program. Toxicology and Carcinogenesis Studies of Naphthalene (CAS No. 91-20-3) in B6C3F1 Mice (Inhalation Studies). Natl Toxicol Program Tech Rep Ser. 1992 Apr;410:1-172.

Navarrete-Palacios E, Hudson R, Reyes-Guerrero G, Guevara-Guzmán R. Correlation between cytological characteristics of the nasal epithelium and the menstrual cycle. Arch Otolaryngol Head Neck Surg. 2003;129(4):460-463. 
Nebert DW, Dalton TP, Okey AB, Gonzalez FJ. Role of aryl hydrocarbon receptor-mediated induction of the CYP1 enzymes in environmental toxicity and cancer. J Biol Chem. 2004 Jun 4;279(23):23847-50.

Nukaya M, Moran S, Bradfield CA. The role of the dioxin-responsive element cluster between the Cyp1a1 and Cyp1a2 loci in aryl hydrocarbon receptor biology. Proc Natl Acad Sci USA. 2009;106:4923-4928.

Okamura E, Wakai C, Matubayasi N, Sugiura Y, Nakahara M. Limited slowdown of endocrine-disruptor diffusion in confined fluid lipid membranes. Phys Rev Lett. 2004 Dec 10;93(24):248101.

Parke DV, loannides C. The effects of nutrition on chemical toxicity. Drug Metab Rev. 1994;26(4):739-65.

Philpott CM, Conboy P, Al-Azzawi F, et al. Nasal physiological changes during pregnancy. Clin Otolaryngol Allied Sci. 2004;29:343-351.

Philpott CM, Wild DC, Wolstensholme CR, Murty GE. The presence of ovarian hormone receptors in the nasal mucosa and their relationship to nasal symptoms. Rhinology. 2008;46:221-5.

Piccinni MP, Giudizi MG, Biagiotti $R$, et al. Progesterone favors the development of human $\mathrm{T}$ helper cells producing Th2-type cytokines and promotes both IL-4 production and membrane CD30 expression in established Th1 cell clones. J Immunol. 1995;155:128-133.

Pope CA 3rd, Burnett RT, Thurston GD, Thun MJ, Calle EE, Krewski D, Godleski JJ. Cardiovascular mortality and long-term exposure to particulate air pollution: epidemiological evidence of general pathophysiological pathways of disease. Circulation. 2004 Jan 6;109(1):71-7.

Prescott E, Bjerg AM, Andersen PK, Lange P, Vestbo J. Gender difference in smoking effects on lung function and risk of hospitalization for COPD: results from a Danish longitudinal population study. Eur Respir J. 1997;10:822-827.

Raza H, John A, Nemmar A. Short-term effects of nose-only cigarette smoke exposure on glutathione redox homeostasis, cytochrome P450 1A1/2 and respiratory enzyme activities in mice tissues. Cell Physiol Biochem. 2013;31(45):683-692.

Robinson AM, Philpott CM, Gaskin JA, Wolstenholme CR, Murty GE. The effect of female hormone manipulation on nasal physiology. Am J Rhinol. 2007 NovDec;21(6):675-9.

Rose MC and Voynow JA. Respiratory Tract Mucin Genes and Mucin Glycoproteins in Health and Disease. Physiol Rev. 2006;86:245-278.

Rudel RA, Camann DE, Spengler JD, Korn LR, Brody JG. Phthalates, alkylphenols, pesticides, polybrominated diphenyl ethers, and other endocrine- 
disrupting compounds in indoor air and dust. Environ Sci Technol. 2003 Oct $15 ; 37(20): 4543-53$.

Rushmore TH, Kong AN. Pharmacogenomics, regulation and signaling pathways of phase I and II drug metabolizing enzymes. Curr Drug Metab. 2002;3(5):481-490.

Safe S, Wormke M. Inhibitory aryl hydrocarbon receptor-estrogen receptor alpha cross-talk and mechanisms of action. Chem Res Toxicol.2003;16:807816.

Saldiva PH, Parada MA, Macchione M, Paiva PS, Guimarães ET, Lorenzi G, et al. Nasal mucus clearance in rats: differences with sex and phase of the oestrous cycle. J Appl Toxicol. 1995;15(4):289-295.

Serra A, Maiolino L, Farina M, et al. Cytologic aspects of the nasal respiratory epithelium throughout the menstrual cycle. Ann Otol Rhinol Larygol. 2004;113:667-71.

Shimada T, Hayes CL, Yamazaki H, Amin S, Hecht SS, Guengerich FP, Sutter TR. Activation of chemically diverse procarcinogens by human cytochrome P450 1B1. Cancer Res. 1996;56(13):2979-2984.

Shimada T, Fujii-Kuriyama Y: Metabolic activation of polycyclic aromatic hydrocarbons to carcinogens by cytochromes P450 1A1 and 1B1. Cancer Sci. 2004;95:1-6.

Shirasaki H, Watanabe K, Kanaizumi E, Konno N, Sato J, Narita S, Himi T. Expression and localization of steroid receptors in human nasal mucosa. Acta Otolaryngol. 2004; Oct;124(8):958-963.

Sidhu S, Gullett B, Striebich R, Klosterman J, Contreras J, DeVito M. Endocrine disrupting chemical emissions from combustion sources: diesel particulate emissions and domestic waste open burn emissions. Atmos Environ 2005;39:801-811.

Siegfried JM. Early changes in pulmonary gene expression following tobacco exposure shed light on the role of estrogen metabolism in lung carcinogenesis. Cancer Prev Res. 2010;3(6):692-695.

Silverman EK, Weiss ST, Drazen JM, Chapman HA, Carey V, Campbell EJ, Denish P, Silverman RA, Celedon JC, Reilly JJ, Ginns LC, Speizer FE. Genderrelated differences in severe, early-onset chronic obstructive pulmonary disease. Am J Respir Crit Care Med. 2000;162:2152-8.

Simon P. Q-Gene: processing quantitative real-time RT-PCR data. Bioinformatics. 2003;Jul 22;19(11):1439-40.

Sioutas C, Delfino RJ, Singh M. Exposure assessment for atmospheric ultrafine particles (UFPs) and implications in epidemiologic research. Environ Health Perspect. 2005;113(8):947-955. 
Srám RJ, Binkova B, Dejmek J, Bobak M. Ambientairpollutionand pregnancy outcomes:areviewoftheliterature. Environ. Health Perspect. 2005;113,375-382.

Stelck RL, Baker GL, Sutherland KM, Van Winkle LS. Estrous cycle alters naphthalene metabolism in female mouse airways. Drug Metab Dispos. 2005 Nov;33(11):1597-602.

Stübner UP, Gruber D, Berger UE, Toth J, Marks B, Huber J, Horak F. The influence of female sex hormones on nasal reactivity in seasonal allergic rhinitis. Allergy. 1999 Aug;54(8):865-71.

Takizawa $\mathrm{H}$. Airway epithelial cells as regulators of airway inflammation (Review). Int J Mol Med. 1998 Feb;1(2):367-78.

Talal N, Ansar Ahmed S. Immunomodulation by hormones an area of growing importance. J Rheumatol. 1987;14:191-193.

Toppozada H, Michaels L, Toppozada M, El-Ghazzawi E, Talaat A, Elwany S. The human nasal mucosa in the menstrual cycle. A histochemical and electron microscopic study. J Laryngol Otol. 1981;95(12):1237-1247.

Townsend EA, Miller VM, Prakash YS. Sex differences and sex steroids in lung health and disease. Endocr Rev. 2012;33(1):1-47.

van Lipzig MM, Vermeulen NP, Gusinu R, Legler J, Frank H, Seidel A, Meerman $\mathrm{JH}$. Formation of estrogenic metabolites of benzo[a]pyrene and chrysene by cytochrome P450 activity and their combined and supra-maximal estrogenic activity. Environ Toxicol Pharmacol. 2005;19(1):41-55.

Van Winkle LS, Gunderson AD, Shimizu JA, Baker GL, Brown CD. Gender differences in naphthalene metabolism and naphthalene-induced acute lung injury. Am J Physiol Lung Cell Mol Physiol. 2002 May;282(5):L1122-34.

Vasconcellos PC, Zacarias D, Pires MAF, Pool CS, Carvalho LRF. Measurements of polycyclic aromatic hydrocarbons in airbone particles from the metropolitan area of São Paulo City, Brazil. Atmospheric Environment. 2003;37:3009-3018.

Veras MM, Damaceno-Rodrigues NR, Guimarães Silva RM, Scoriza JN, Saldiva $\mathrm{PH}$, et al. Chronic exposure to fine particulate matter emitted by traffic affects reproductive and fetal outcomes in mice. Environ Res. 2009;109 (5):536543.

Villeneuve DL, Blankenship AL, Giesy JP. Interactions between environmental xenobiotics and estrogen receptor-mediated responses. In: Denison, MS, Helferich, WG (eds) Toxicant-receptor interactions. Taylor \& Francis, Philadelphia, PA. 1998.

Vione D, Maurino V, Minero C, Lucchiari M, Pelizzetti E. Nitration and hydroxylation of benzene in the presence of nitrite/nitrous acid in aqueous solution. Chemosphere. 2004;56(11):1049-1059. 
Wang J, Xie P, Xu Y, Kettrup A, Schramm K-W. Differing estrogen activities in the organic phase of air particulate matter collected during sunny and foggy weather in a Chinese city detected by a recombinant yeast bioassay. Atmos Environ. 2004;38:6157-6166.

Wardlaw SA, Nikula KJ, Kracko DA, Finch GL, Thornton-Manning JR, Dahl AR. Effect of cigarette smoke on CYP1A1, CYP1A2 and CYP2B1/2 of nasal mucosae in F344 rats. Carcinogenesis. 1998 Apr;19(4):655-62.

Watanabe M, Tanaka M, Tateishi T, Nakura H, Kumai T, Kobayashi S. Effects of the estrous cycle and the gender differences on hepatic drug-metabolising enzyme activities. Pharmacol Res. 1997;35(5):477-480.

Watanabe N, Kurita M. The masculinization of the fetus during pregnancy due to inhalation of diesel exhaust. Environ. Health Perspect. 2001;109:111-119.

Wenger D, Gerecke AC, Heeb NV, Schmid P, Hueglin C, Naegelib H and Zenobic R. In vitro estrogenicity of ambient particulate matter: contribution of hydroxylated polycyclic aromatic hydrocarbons. J Appl Toxicol. 2009;29:223232.

Wilkinson J 4th, Clapper ML. Detoxication enzymes and chemoprevention. Proc Soc Exp Biol Med. 1997 Nov;216(2):192-200.

Wise RA. Changing smoking patterns and mortality from chronic obstructive pulmonary disease. Prev Med. 1997;26:418-21.

Wu WX, Owiny J, Zhang Q, Ma XH, Nathanielsz PW. Regulation of the estrogen receptor and its messenger ribonucleic acid in the ovariectomized sheep myometrium and endometrium: the role of estradiol and progesterone. Biol Reprod. 1996;55(4):762-768.

Yoshizaki K, Brito JM, Toledo AC, Nakagawa NK, Piccin VS, Junqueira MS, Negri EM,et al. Subchronic effects of nasally instilled diesel exhaust particulates on the nasal and airway epithelia in mice. Inhal Toxicol. 2010;22(7):610-617.

Zacharewski TR, Meek MD, Clemons JH, Wu ZF, Fielden MR, Matthews JB. Examination of the in vitro and in vivo estrogenic activities of eight commercial phthalate esters. Toxicol Sci. 1998;46(2):282-293. 
ANEXO 


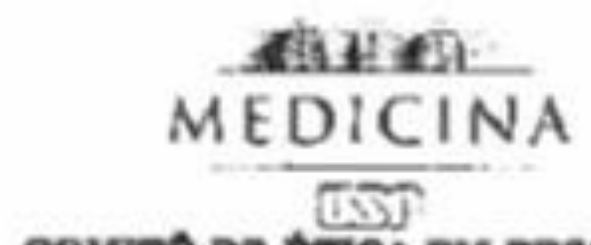

COMTRE DE tTICA EM PESQULSA

A CruU do Comitt de ttica en Ponquisa da Faculdade de Medicina da Universidade de SWo Paulo, em seavio de iB.o8.10, APROVOU o Protocolo de Pescula $n^{\circ}$ 178/10 intitolador "EFErTO DA PARTICIPAClO DE ESTEROIDES LIKE PRONENIENTE DA POLUICXO ATMOSFERICA NO

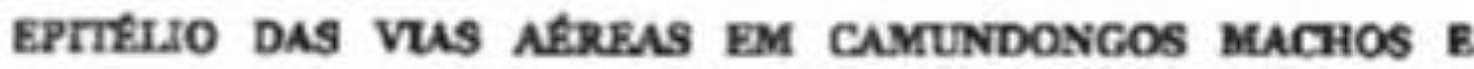
FEMEAS" e seus aneros, que utilliart 14 camundongoe machos e 56 femess da linhagem bellb/e, apresentado pelo Departarneato de Fatologia.

Cabe so pesquiseder elaborar e apresentar so CEP-FMUSP, e relatbrio fisal sobre a pesquisa, ( Lei Procedimentos pars o Uso Cientifioo de Animais - Lei No $11.794-8$ de outubro de 2008).

Pesquisedor (a) Responatvelt Mariangela Macehilone

Pescuisedor ( $\bullet$ ) Executante : Kelly Yoshizakd

CEP-FMUSP, 18 de agosto de 2010.

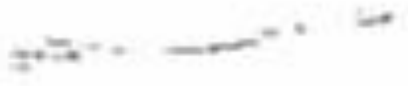

Dr. Bdeardo Pompeu

Coordenador

Coenimalo de Btice no Uno de Anlmais

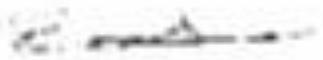

Pret. Dr. Eduarde Masend

Coordenador

Coout te de Rties en Pesquls.

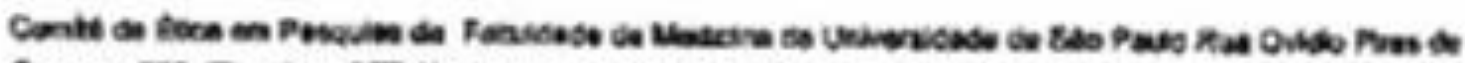

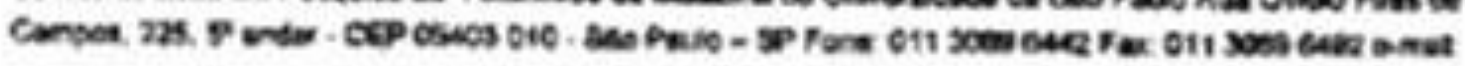

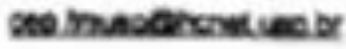

